Universidade de São Paulo

MARIA ROSA C. KUSHNIR

Biblioteca universitária e formação cultural: diretrizes e representações em instituições de educação superior

São Paulo

2021 
MARIA ROSA C. KUSHNIR

\title{
Biblioteca universitária e formação cultural: diretrizes e representações em instituições de educação superior
}

\author{
Versão Corrigida \\ (Versão original encontra-se na Biblioteca da Escola de Comunicações e Artes)
}

Dissertação apresentada à Escola de Comunicações e Artes da Universidade de São Paulo para obtenção do título de Mestre em Ciência da Informação.

Área de Concentração: Cultura e Informação

Orientadora: Profa. Dra. Ivete Pieruccini

São Paulo 
Autorizo a reprodução e divulgação total ou parcial deste trabalho, por qualquer meio convencional ou eletrônico, para fins de estudo e pesquisa, desde que citada a fonte.

Catalogação na Publicação

Serviço de Biblioteca e Documentação

Escola de Comunicações e Artes da Universidade de São Paulo

Dados inseridos pelo(a) autor(a)

Kushnir, Maria Rosa Carnicelli

iretrizes e representações em instituições de educação

superior / Maria Rosa Carnicelli Kushnir; orientadora,

Ivete Pieruccini. - São Paulo, 2021.

$123 \mathrm{p}$.

Dissertação (Mestrado) - Programa de Pós-Graduação en Ciência da Informação / Escola de Comunicações e Artes / Universidade de São Paulo.

Bibliografia

Versão corrigida

1. Biblioteca universitária. 2. Universidade. 3 .

Bibliotecas especializadas. 4. Ensino superior. 5.

Formação cultural. I. Pieruccini, Ivete. II. Título.

CDD 21.ed. - 020

Elaborado por Alessandra Vieira Canholi Maldonado - CRB-8/6194 
Nome: KUSHNIR, Maria Rosa Carnicelli

Título: Biblioteca universitária e formação cultural: diretrizes e representações em instituições de educação superior

Dissertação apresentada à Escola de Comunicações e Artes da Universidade de São Paulo para obtenção do título de Mestre em Ciência da Informação.

Aprovado em:

Banca Examinadora

Prof. Dr.

Instituição:

Julgamento:

Prof. Dr.

Instituição:

Julgamento:

Prof. Dr.

Instituição:

Julgamento: 


\section{AGRADECIMENTOS}

Quando comecei a pensar nestes agradecimentos, uma amiga muito querida publicou em uma rede social um texto sobre a relação dela com o ato de agradecer, seus rituais e significados. No meu percurso, que durou o tempo do mestrado, muitas pessoas foram importantes. Algumas são minhas companheiras de outras jornadas, algumas conheci durante este processo, umas chegaram como uma linda surpresa, outras foram por novos caminhos.

Acho que nem todas essas pessoas sabem, mas nutro um afeto cheio de ternura por todas elas. Por ter receio de esquecer alguém, meus agradecimentos não serão individualizados, mas, mesmo assim, são sinceros.

Sou grata:

A todos os colegas da USP e da ECA, por partilharem conversas e ideias!

Aos colegas de trabalho da Unifesp Osasco, mas principalmente à equipe da Biblioteca Eppen, a equipe mais sensacional do universo!

Às Queridas do Coração, por todo carinho e apoio de sempre e, especialmente, por estarem presentes em momentos difíceis!

Aos amigos da Bruxaria e das Runas, pela generosidade e pelas experiências transcendentais!

À minha família, pela paciência e pelo entendimento, mas principalmente pelo companheirismo nesta trilha que se mostra em constante movimento!

Para mim, é sempre um prazer e uma honra compartilhar a vida com vocês! 


\section{Epígrafe}

Marco Polo descreve uma ponte, pedra por pedra.

- Mas qual é a pedra que sustenta a ponte? - pergunta Kublai Khan.

- A ponte não é sustentada por esta ou aquela pedra - responde Marco -, mas pela curva do arco que estas formam.

Kublai Khan permanece em silêncio, refletindo. Depois acrescenta:

- Por que falar das pedras? Só o arco me interessa.

Polo responde:

- Sem pedras o arco não existe.

(CALVINO, 1997, p. 79) 


\section{RESUMO}

KUSHNIR, Maria Rosa C. Biblioteca universitária e formação cultural: diretrizes e representações em instituições de educação superior. 2021. Dissertação (Mestrado em Ciência da Informação) - Escola de Comunicações e Artes, Universidade de São Paulo, São Paulo, 2021.

Este trabalho trata da biblioteca universitária e sua relação com a universidade, refletindo e questionando sobre seu papel como organismo de formação cultural. Tendo em vista observar essa relação biblioteca/universidade, fez-se a opção metodológica pela pesquisa qualitativa, descritiva, fundamentada em pesquisa bibliográfica e documental, baseada em revisão de literatura integrativa, e usou-se a Análise do Discurso como ferramenta para analisar os documentos que regem as universidades selecionadas e seus respectivos sistemas de bibliotecas. A biblioteca universitária é reflexo da instituição da qual faz parte, integrando políticas e culturas do universo acadêmico. Reconhecer e compreender o contexto dessa biblioteca é questão de base a possíveis transformações. Visando torná-la dispositivo essencial na Educação Superior, não mera instância acessória, a pesquisa pretende sistematizar referenciais que estão na base do conceito de biblioteca universitária brasileira, tendo em vista identificar e compreender o lugar formalmente estabelecido que ocupa na ordem acadêmica; levantar parâmetros conceituais e metodológicos que orientam atuação dessas bibliotecas; identificar categorias constitutivas de seus parâmetros de orientação; refletir sobre seu papel como organismo de formação cultural. O estudo considerou conceitos de modelo universitário, biblioteca universitária, dispositivo cultural e formação cultural. O processo de análise das diretrizes de três universidades selecionadas e de suas respectivas bibliotecas universitárias, a saber: Universidade de Campinas (Unicamp), Universidade de São Paulo (USP) e Universidade Federal de São Paulo (Unifesp) visou identificar discursos articulando a biblioteca universitária e a formação cultural. Ao utilizarmos a Análise do Discurso para interpretar as diretrizes selecionadas, foi possível discutir a relação da biblioteca universitária com a universidade levando-se em consideração os seguintes aspectos: a formação cultural e a representação dos discursos; os sistemas e a autonomia; o esquecimento institucional dos órgãos complementares; e 
a biblioteca universitária como dispositivo. O conceito de esquecimento, oriundo da Análise do Discurso, contribuiu para a reflexão sobre o papel da biblioteca universitária presente nas diretrizes. Ao se esquecer do papel educativo das bibliotecas universitárias, esvazia-se o potencial desses dispositivos culturais enquanto espaços dialógicos, com complexo papel na formação cultural de toda a comunidade universitária. As diretrizes instituíram as competências técnicas de suas bibliotecas, mas não discutiram suas dimensões ética, estética, cognitiva e política.

Palavras-chave: Biblioteca universitária. Universidade. Bibliotecas especializadas. Ensino superior. Formação cultural. 


\begin{abstract}
KUSHNIR, Maria Rosa C. University library and cultural formation: guidelines and representations in higher education institutions. Dissertação (Mestrado em Ciência da Informação) - Escola de Comunicações e Artes, Universidade de São Paulo, São Paulo, 2021.
\end{abstract}

This work deals with the university library and its relationship with the university, reflecting and questioning its role as an organism of cultural formation. In order to observe this library/university relationship, a methodological option was made for qualitative, descriptive research, based on bibliographic and documentary research, based on an integrative literature review, and Discourse Analysis was used as a tool to analyze the documents governing selected universities and their respective library systems. The university library is a reflection of the institution to which it belongs, integrating policies and cultures of the academic universe. Recognizing and understanding the context of this library is a basic issue for possible transformations. Aiming to make it an essential device in Higher Education, not merely an accessory instance, the research intends to systematize references that are at the base of the concept of the Brazilian university library, in order to identify and understand the formally established place it occupies in the academic order; to raise conceptual and methodological parameters that guide their performance; to identify categories constituting the parameters of their orientation; reflect on its role as a cultural formation organization. The study considered concepts of university model, university library, cultural device and cultural formation. The process of analyzing the guidelines of three selected universities and their respective university libraries, namely: Universidade de Campinas (Unicamp), Universidade de São Paulo (USP) and Universidade Federal de São Paulo (Unifesp) aimed at identifying speeches articulating the university library and cultural formation. When using Discourse Analysis to interpret the selected guidelines, it was possible to discuss the relationship between the university library and the university taking into account the following aspects: cultural formation and the representation of discourses; systems and autonomy; the institutional neglect of complementary bodies; and the university library as a device. The concept of forgetfulness, derived from Discourse Analysis, 
contributed to the reflection on the role of the university library present in the guidelines. By forgetting the educational role of university libraries, the potential of these cultural devices is emptied as dialogical spaces, with a complex role in the cultural formation of the entire university community. The guidelines established the technical skills of their libraries, but did not discuss their ethical, aesthetic, cognitive and political dimensions.

Keywords: University library. University. Specialized libraries. Higher education. Cultural formation. 


\section{LISTA DE FIGURAS}

Figura 1 Página da IFLA utilizando definição proposta pela ALA .................................56

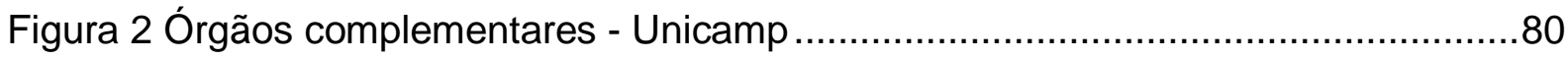

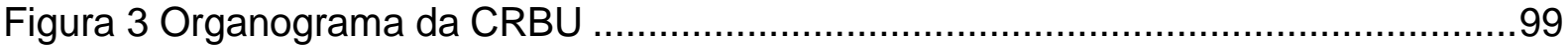

Figura 4 Equipe que compõe a CRBU....................................................................100 


\section{SUMÁRIO}

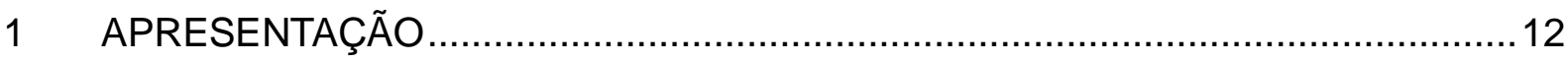

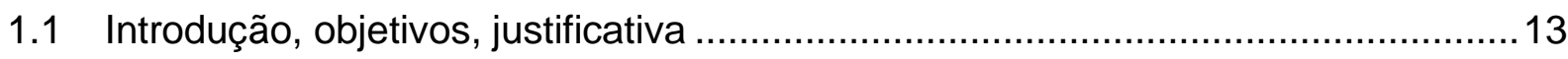

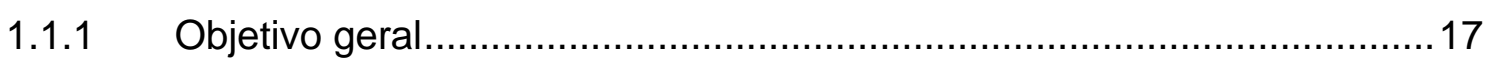

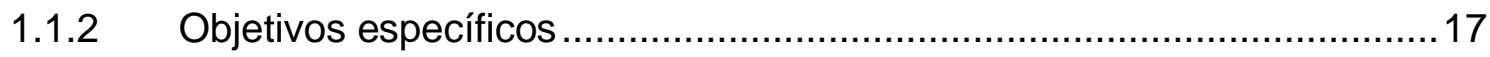

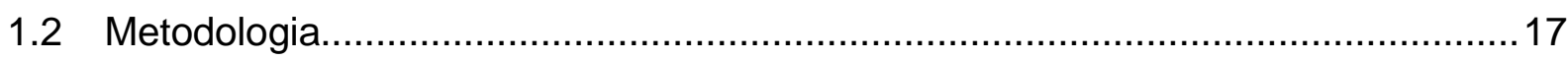

1.2.1 Sobre o tema e o objeto de pesquisa .............................................. 19

1.2.2 Seleção de fontes .......................................................................20

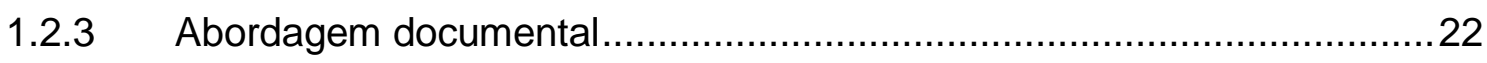

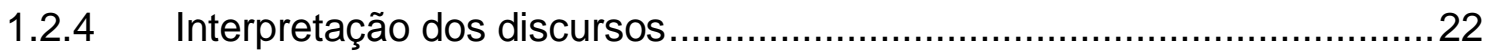

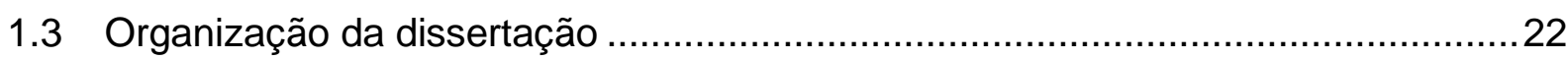

2 A ORDEM UNIVERSITÁRIA: MODELOS, DISPOSITIVOS E FORMAÇÃO

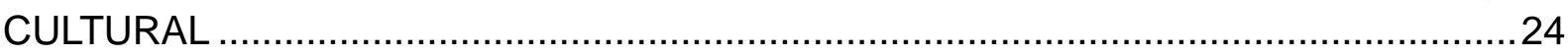

2.1 Universidade: características e finalidades das instituições de ensino superior.....24

2.1.1 Universidades da Europa: o surgimento de modelos ..........................24

2.1.2 Modelo francês (ou napoleônico): caráter instrumental ..........................28

2.1.3 Modelo alemão: ênfase na pesquisa ................................................... 31

2.1.4 Modelo inglês: ênfase na educação liberal ........................................ 32

2.1.5 Modelo estado-unidense: ênfase na ideia de progresso .........................34

2.1.6 Universidade no Brasil: amálgama de modelos...................................40

2.1.7 Processo de Bolonha............................................................... 49

2.1.8 Influências do Processo de Bolonha no Brasil.......................................50

2.2 Biblioteca universitária: bases conceituais.................................................. 51

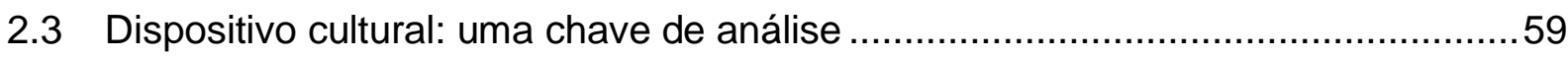

2.4 Formação cultural: um paradigma para a biblioteca universitária..........................62

2.4.1 Dimensões de Bildung ........................................................... 64

2.4.2 Críticas ao conceito de Bildung ................................................... 67 
3 BIBLIOTECA UNIVERSITÁRIA E ESTRUTURA ACADÊMICA: ANÁLISE DE

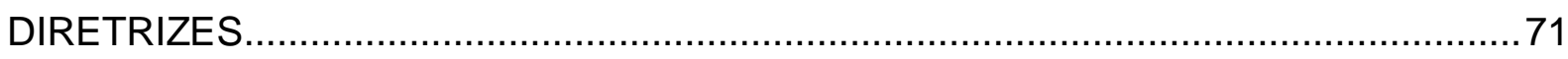

3.1 Universidade de Campinas (Unicamp) ……………........................................ 72

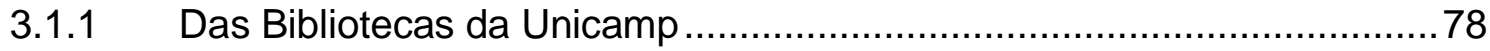

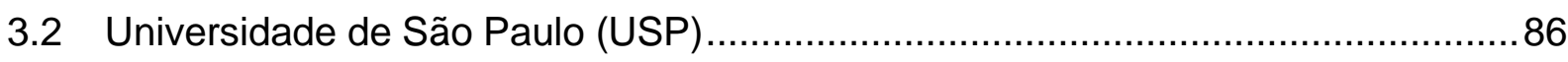

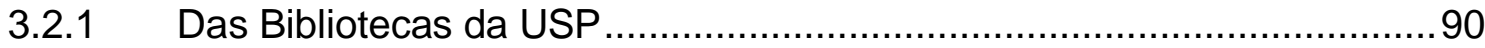

3.3 Universidade Federal de São Paulo (Unifesp) .................................................

3.3.1 Da Coordenadoria da Rede de Bibliotecas da Unifesp (CRBU) ...............98

4 BIBLIOTECA UNIVERSITÁRIA E FORMAÇÃO CULTURAL: REPRESENTAÇÕES

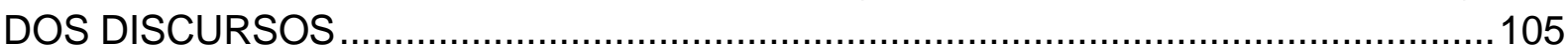

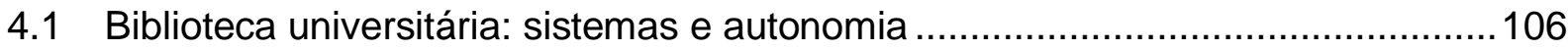

4.2 Biblioteca universitária: órgãos complementares e esquecimento institucional ... 107

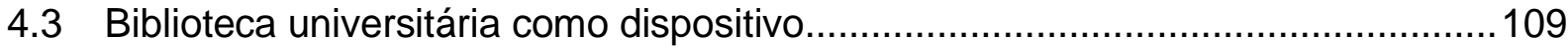

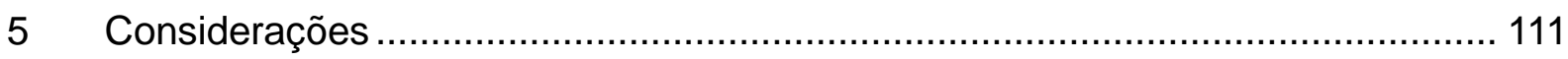

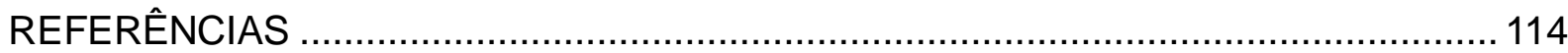




\section{APRESENTAÇÃO}

O trabalho como bibliotecária em biblioteca universitária $(\mathrm{BU})$ da rede universitária federal permitiu-me experiências significativas, que me mobilizaram em busca de compreender a problemática que envolve esse organismo no País.

Há algum tempo, a biblioteca recebeu uma doação de livros não científicos, que incluía romances, ficção científica, mangás, entre outros e, após discussões com a equipe sobre o procedimento mais adequado para a inserção (ou não) desses livros em especial, definimos pelo procedimento técnico para disponibilizá-los no acervo seguindo protocolos posteriores já conhecidos, como exposição de alguns exemplares e substituição periódica dos itens.

A receptividade dos alunos foi boa, com demonstração de interesse pelos livros, realização de empréstimos e manifestação de familiaridade, pelos estudantes, de alguns dos títulos expostos. Essa atividade, a partir da pequena doação de títulos, gerou um burburinho entre os frequentadores da biblioteca. Percebemos um significativo aumento na movimentação entre os estudantes, com indicações de livros, comentários espontâneos sobre o que haviam lido e até propostas de ações para a obtenção de outras doações para a biblioteca, bem como para a comunidade do entorno.

A situação era intrigante, considerando-se aquele contexto: como uma ação despretensiosa da biblioteca, fora de seu escopo rotineiro, ou seja, de sua função específica de atendimento à comunidade escolar acadêmica, passou a ser um gatilho para que estudantes interagissem com tal ênfase, construíssem relações entre si, estabelecendo vínculos e se organizando para atuar além do circuito da biblioteca e até mesmo da universidade, de forma tão orgânica.

Entretanto, a ação teve desdobramentos em outra direção, mais subjetiva: comecei a me questionar sobre o próprio papel da biblioteca universitária em contextos específicos, como o da cultura brasileira. Se pensarmos a BU como instância integradora das relações do estudante com a cultura acadêmica, qual a relevância da adesão dos estudantes nessas atividades que estão fora do propósito desse tipo 
específico de biblioteca? Minha própria experiência como aluna da Universidade de São Paulo era a referência mais significativa de que as demandas próprias a uma BU são de outra natureza, por vezes dificilmente conciliáveis a ações de cultura e extensão, como se configurou a experiência vivida.

A partir disso, percebi que o papel cultural da biblioteca universitária me intrigava, o que impulsionou o questionamento acerca das representações em torno dessa biblioteca, em face à percepção dos descompassos mais ou menos gerais em torno das problemáticas a serem consideradas e atendidas pela biblioteca universitária, na contemporaneidade, dentro de cenários acadêmicos fragilizados, tais como o nosso. Por um lado, a BU não pode alienar-se de seu essencial e insubstituível papel na construção de relações entre sujeitos e a cultura científica/acadêmica, por outro lado, são indiscutíveis as dificuldades que o novo público universitário tem para incorporar a BU ao seu cotidiano, tal como ela se apresenta.

\subsection{Introdução, objetivos, justificativa}

As bibliotecas universitárias como organismos integrados às instituições de ensino superior - institutos, faculdades e universidades -, que atendem aos estudantes, docentes e funcionários, incorporam características dessas instituições as quais pertencem, devendo inserir-se no circuito institucional de produção intelectual, científica e cultural, orientando-se pelos seus objetivos e transitando pelas esferas dinamicamente articuladas do ensino, pesquisa e extensão, tripé que caracteriza a universidade pública em nosso país.

Repercute na biblioteca universitária a dificuldade de apropriação dos bens simbólicos por boa parcela de seu público. O estudante de nível superior, embora apto a ingressar na universidade, não é, via de regra, familiarizado com as bibliotecas em geral e, muitas vezes, apresenta outras dificuldades correlatas à leitura, o que levanta barreiras ao exercício pleno do papel da biblioteca universitária. A privação de bibliotecas na vida discente, desde os níveis escolares 
fundamentais, produz uma legião de estudantes universitários não-iniciados nas tramas, lógicas e linguagens dos ambientes informacionais acadêmicos, o que compromete a relação, ou a maturação, de processos de diálogo com a produção de conhecimento científico; isso pode ser corroborado pelos dados do Censo da Educação Básica 2019, segundo o qual 56,3\% das escolas de ensino fundamental possuem biblioteca ou sala de leitura; esse índice aumenta para 88,2\% nas escolas de ensino fundamental, porém esses dados não dão conta da porcentagem de alunos que frequentam essas bibliotecas/salas de leitura, nem com que frequência 0 fazem (BRASIL, 2020). Além desses dados quantitativos, por não definir o que é biblioteca e considerar a resposta dos dirigentes, o Censo coloca no mesmo patamar bibliotecas e salas de leitura, o que nos leva a pensar que é possível que a pesquisa considere uma coleção de livros como biblioteca.

Esses contextos socioculturais e educacionais complexos e diversos sinalizam dificuldades e fragilidades nas relações entre sujeitos e bibliotecas, que remetem a concepções de bibliotecas universitárias, seus modos de funcionamento, finalidades e práticas culturais, que dizem respeito a esferas da formação de quadros capazes, e por vezes ávidos, de diálogo com o patrimônio cultural existente.

Parece claro que a falta de experiências culturais diversificadas próprias às dinâmicas vividas em bibliotecas públicas, bem como de aprendizagens pertinentes aos objetivos das chamadas bibliotecas escolares - um dos primeiros espaços, por princípio, de contato da criança com ambiente de informação organizado e especialmente dedicado a oferecer condições de penetrar neste universo - traz consigo uma gama de entraves à apropriação das bibliotecas universitárias como bens culturais e compromete, certamente, a construção do pensamento universitário.

Em contrapartida, diante desse descompasso, a busca de alternativas capazes de, talvez, compensar esses hiatos impostos por políticas descontínuas de bibliotecas apresenta-se como caminho mais imediato, em face ao retorno positivo de algumas práticas que acabam por mobilizar o interesse e o envolvimento de estudantes. A permanecer lamentando o distanciamento entre biblioteca e estudante, desenvolver 
ações mais próximas do universo dos jovens universitários mostra-se urgente, proveitoso e promissor no intuito de propiciar condições favoráveis ao trânsito autônomo por distintos contextos informacionais, aspecto com reflexos diretos sobre os rumos do projeto de conhecimento e participação do estudante na vida acadêmica.

O Seminário Nacional de Bibliotecas Universitárias, de 2018, traz trabalhos que relatam ações culturais em BU, exemplos dessa tentativa de compensação das experiências culturais, mas que partem de uma perspectiva de oferecimento de bens culturais, numa transmissão de cima para baixo, que se evidencia com o uso de expressões como "promoção" e "difusão" do acervo e de informações.

De fato, a diversidade de aspectos em torno das relações entre a BU e seus públicos é questão que afeta seu papel efetivo na construção do diálogo com a comunidade estudantil e, em decorrência, com o conhecimento científico e sua participação na ordem universitária, a qual se inscreve na formação de sujeitos de pensamento complexo, abrangente, articulado às questões humanas mais amplas, aspecto que implica considerá-la em seu caráter essencial e não meramente acessório no processo de formação cultural.

Com claras evidências, o papel das bibliotecas em todo o mundo foi afetado pela ordem informacional que se impôs sobre a sociedade, sobretudo após os anos de 1980 e 1990. Em texto de 2005, Sally Burch indaga "Como caracterizar as profundas transformações que acompanham a acelerada introdução na sociedade da inteligência artificial e as novas tecnologias da informação e da comunicação (TIC)?" (2005, p. 1) e afirma que "sociedade da informação" é um conceito construído politica e ideologicamente, propagado pela "globalização neoliberal" que defende um mercado autorregulado, aumentando a separação entre ricos e pobres. Ela também apresenta o termo "sociedade do conhecimento", adotado pela Unesco, que é fruto de reflexões acerca de uma concepção integral, e não só econômica, abrangendo "uma dimensão de transformação social, cultural, econômica, política e institucional, assim como uma perspectiva mais pluralista e de desenvolvimento". 
Esses dois termos acabam contrapondo dois pontos de vista: por um lado, a tecnologia passa a ser a causa do desenvolvimento econômico. Por outro, a tecnologia não é vista como fator neutro, ao contrário, como diz Burch, "nem seu rumo é inexorável, posto que o próprio desenvolvimento tecnológico seja orientado por jogos de interesses" (2005, p. 5).

Como em relação a todas as demais modalidades de biblioteca, é preciso, então, discutir os papéis da BU como dispositivo essencial dessa ordem e rever suas representações, não somente como disseminadora de informação científica. Buscar compreender que a BU não é mero canal ou suporte de veiculação de conteúdos informacionais, mas sim instância produtora de significados, permite introduzir uma ótica especial, ainda pouco explorada, segundo nossa hipótese.

A biblioteca universitária está, assim, pressionada por diferentes fatores, seja no âmbito das carências que marcam as relações entre biblioteca e sociedade de modo geral, seja em razão da nova ordem informacional contemporânea que vem determinando o valor e o caráter da informação na contemporaneidade, ambos aspectos que afetam sua atuação no contexto acadêmico, em especial em nosso país.

Como organismo inscrito em instituição de ensino superior, a biblioteca universitária tem caráter educativo: é não somente ambiente de informação, como também, em consonância com os parâmetros da universidade, equipamento educativo, instância de mediação do patrimônio informacional científico, cujas essencialidade e centralidade implicam sujeitos e processos de criação de sentidos às dinâmicas de construção do conhecimento.

Em um país em que a relação com o patrimônio simbólico escrito é frágil, é necessário haver clareza no fato de existir uma situação real e concreta de descontextualização informacional que reflete em nós da mesma maneira, ou seja, produz pensamento fragmentário, alterando também a ordem do pensar e do significar. 
É importante a reflexão sobre a BU enquanto dispositivo cultural mediador dessas relações dos sujeitos e local de possibilidade de experimentações. Nesse sentido, há que se interrogar sobre as consonâncias entre o papel da universidade e o papel da biblioteca universitária e sua contribuição na formação cultural dos estudantes.

Assim, a partir da análise das diretrizes selecionadas, este trabalho traz reflexões acerca das concepções da biblioteca universitária e suas características, bem como questiona de forma criteriosa qual o papel da biblioteca universitária em quadros educacionais problemáticos na contemporaneidade, como os enfrentados no Brasil.

\subsubsection{Objetivo geral}

Sistematizar referenciais que estão na base do conceito de biblioteca universitária brasileira, tendo em vista identificar e compreender o lugar formalmente estabelecido que ocupa na ordem acadêmica.

\subsubsection{Objetivos específicos}

- Levantar parâmetros conceituais e metodológicos que orientam atuação das BUs.

- Identificar categorias constitutivas dos parâmetros de orientação das BUs.

- Refletir sobre o papel da BU como organismo de formação cultural.

\subsection{Metodologia}

$\mathrm{O}$ atendimento aos objetivos propostos neste trabalho assenta-se em pesquisa bibliográfica e documental. Conforme Gil (2008, p. 50), a pesquisa bibliográfica é aquela "desenvolvida a partir de material já elaborado, constituído principalmente de 
livros e artigos científicos". Para o autor, a pesquisa documental se diferencia da bibliográfica em função da natureza das fontes, ou seja, utiliza "materiais que não receberam ainda um tratamento analítico, ou que ainda podem ser reelaborados de acordo com os objetivos da pesquisa".

De modo objetivo, o estudo considerou:

a) a abordagem de literatura sobre biblioteca universitária, identificando referenciais que alicercem os conceitos de modelo universitário, biblioteca universitária e formação cultural. Destacamos o trabalho dos seguintes autores: Biesta; Budd; Cunha; Ferreira; Meneghel; Möllmann; Nicolau; Severino; Sguissardi.

b) a análise de documentação referente aos estatutos e regimentos das universidades e suas bibliotecas, os quais foram coletados em dezembro de 2018.

As diretrizes selecionadas foram abordadas a partir da Análise do Discurso (AD), segundo conceitos desenvolvidos por Eni P. Orlandi, com base na escola francesa de AD.

Uma das categorias centrais da metodologia de Orlandi é denominada desuperficialização, da qual desdobram-se três eixos de abordagem dos documentos: como se diz, quem diz e em quais circunstâncias. De modo complementar, os conceitos de esquecimento que a autora desenvolve, tanto o esquecimento da enunciação como o esquecimento ideológico, se configuraram como ferramentas para a análise do discurso das diretrizes selecionadas.

A opção metodológica adotada é a da pesquisa qualitativa, descritiva, com base, portanto, na busca de contextos que envolvem as universidades e as bibliotecas universitárias, bem como suas trajetórias históricas. O corpus de análise selecionado visa oferecer elementos para a identificação de desafios e problemáticas que se interpõem aos percursos das BUs, na perspectiva educativa compreendidas como instâncias produtoras de significados capazes de interferir na formação cultural dos estudantes. 
Tendo como base a revisão de literatura integrativa (Mendes; Silveira; Galvão, 2008), adotamos abordagem planejada das fontes, de forma sistemática para analisar tendências, identificar, selecionar e avaliar estudos, tais como revisões teóricas, relatórios etc.

Com base no trabalho de Broome, a revisão integrativa é aquela em que pesquisas anteriores são resumidas, tirando conclusões de muitos estudos. O método de revisão integrativa permite a combinação de dados da literatura empírica e teórica que podem ser direcionados à definição de conceitos, identificação de lacunas nas áreas de estudos, revisão de teorias e análise metodológica dos estudos sobre um tópico específico.

A conjugação de pesquisas com diferentes métodos combinados na revisão integrativa amplia as possibilidades de análise da literatura, no âmbito do problema estudado. Assim, esta revisão integrativa será direcionada a identificar tendências da BU enquanto dispositivo de formação cultural.

A seguir apresentamos as etapas constituintes da revisão integrativa.

\subsubsection{Sobre o tema e o objeto de pesquisa}

A identificação do tema e seleção da questão para a elaboração da revisão constitui a primeira etapa do processo, em que os descritores ou palavras-chave são identificados para a execução da busca dos estudos. A identificação das palavraschave relevantes ao estudo tomou por base termos representativos do objeto de estudo, a saber: biblioteca universitária, educação superior, formação cultural, educação cultural e suas respectivas traduções em inglês (academic library, higher education, cultural formation, cultural education). Os termos foram pesquisados no campo "assunto" a partir de recorte temporal (2008-2018) e de idioma (português e inglês). 


\subsubsection{Seleção de fontes}

A seleção de fontes, diretamente ligada à busca em bases de dados, constitui etapa central, tendo em vista tratar-se de processo de identificação dos estudos que serão incluídos na revisão.

O levantamento, por meio da Busca Integrada USP, das bases de dados que abrangem a área de conhecimento "Humanas" e o assunto "Ciência da Informação", permitiu identificar oito bases bibliográficas, a saber:

- Emerald Journals Premier - Coleção de Periódicos

- Information Science \& Technology Abstracts (ISTA)

- JSTOR - Arts and Sciences I

- Library, Information Science \& Technology Abstracts with Full Text

- $\quad$ LISA - Library \& Information Science Abstracts

- SAGE Journals

- Social Science Research Network (SSRN)

- Taylor \& Francis - Coleção de Periódicos

A busca foi realizada nas bases de dados das instituições/entidades a seguir, as quais tratam da biblioteca universitária como objeto, sob diferentes perspectivas:

- Academic and Research Libraries Section (IFLA): https://www.ifla.org/academic-and-research-libraries

- Association of College \& Research Libraries (ACRL) - divisão da ALA: http://www.ala.org/acrl/

- Association of Research Libraries (ARL): https://www.arl.org/ 
- Comissão Brasileira de Bibliotecas Universitárias (CBBU): http://www.febab.org.br/cbbu/

- Ministério da Educação (MEC)/Secretaria de Educação Superior (SESU): http://portal.mec.gov.br/sesu-secretaria-de-educacao-superior/apresentacao

- UNESCO - higher education: https://en.unesco.org/themes/higher-education

Tais instituições dispõem de documentação na qual apresentam recomendações feitas por esses organismos, bem como a legislação vigente no âmbito do ensino superior e das bibliotecas universitárias.

Com o objetivo de verificarmos práticas propostas por bibliotecas universitárias brasileiras, foram selecionadas três instituições nacionais de ensino superior dentre as mais bem avaliadas da América Latina, pela revista inglesa Times Higher Education, no ano de 2018, a saber:

Tabela 1: Universidades selecionadas

\begin{tabular}{lr}
\hline Nome & № geral \\
\hline Universidade de Campinas & 86,5 \\
\hline Universidade de São Paulo & 86,0 \\
\hline Universidade Federal de São Paulo (UNIFESP) & 83,6
\end{tabular}

Fonte: Times Higher Education, 2018.

A escolha da Times Higher Education para seleção das instituições a serem analisadas deu-se em razão da diversidade de indicadores avaliados pela instituição, o que torna equilibrado o posicionamento das universidades tomadas como corpus de análise. Mesmo assim, evidenciou-se três universidades paulistas, duas estaduais e uma federal, no ranking selecionado. 


\subsubsection{Abordagem documental}

O processo de análise dos documentos, fichamento e seleção de informações-chave foi orientado por critério visando identificar discursos articulando a biblioteca universitária e a formação cultural. Assim, por meio do quadro teórico foi possível estabelecer quatro eixos de abordagem: os modelos universitários que formam a base das universidades brasileiras; a biblioteca universitária; o conceito de dispositivo cultural; e o conceito de formação cultural.

\subsubsection{Interpretação dos discursos}

Esta é a fase de discussão dos principais resultados encontrados a partir da comparação com o quadro teórico, identificação de tendências e possíveis implicações. Ao utilizarmos a análise do discurso para interpretar as diretrizes selecionadas, foi possível discutir a relação da BU com a universidade levando-se em consideração os seguintes aspectos: a formação cultural e a representação dos discursos; os sistemas e a autonomia; o esquecimento institucional dos órgãos complementares; e a biblioteca universitária como dispositivo.

\subsection{Organização da dissertação}

Esta dissertação é dividida em capítulos, os quais seguem a ordem subsequente:

Capítulo 1: breve apresentação das razões pessoais que ensejaram este trabalho; introdução ao tema, expressando objetivos e justificativa, bem como elementos essenciais da metodologia utilizada neste trabalho.

Capítulo 2: discussão sobre os conceitos-chave para o desenvolvimento deste trabalho, que constituíram embasamento teórico para análise das diretrizes, a saber: Universidades e seus modelos (francês, alemão, inglês e estado-unidense); Biblioteca universitária; Dispositivo cultural; e Formação cultural. 
Capítulo 3: análise das diretrizes de três universidades selecionadas e de suas respectivas bibliotecas universitárias, a saber: Universidade de Campinas (Unicamp), Universidade de São Paulo (USP) e Universidade Federal de São Paulo (Unifesp). Para isso, utilizamos como ferramenta metodológica a Análise do Discurso e os conceitos trabalhados no Capítulo 2.

Capítulo 4: sistematização das análises referidas no capítulo anterior, em torno de quatro aspectos relativos às bibliotecas universitárias: a formação cultural, os sistemas e a autonomia da BU; a BU enquanto órgão complementar e sua posição na instituição; e, finalmente. a BU como dispositivo cultural.

Considerações finais: síntese das análises e discussões, refletindo o esvaziamento do potencial das BUs enquanto espaços dialógicos, e ponderando o complexo papel desses dispositivos na formação cultural da comunidade universitária. 


\section{A ORDEM UNIVERSITÁRIA: MODELOS, DISPOSITIVOS E FORMAÇÃO CULTURAL}

A trama conceitual que orienta a pesquisa sobre a biblioteca universitária e a formação cultural de estudantes na contemporaneidade implica observar referências que deram base a configurações posteriores, como o que aconteceu no contexto brasileiro.

\subsection{Universidade: características e finalidades das instituições de ensino superior}

Três modelos clássicos de universidade europeia do século XIX, bem como o modelo universitário estado-unidense, contribuem para a compreensão das lógicas e perspectivas que influenciaram a estruturação da universidade brasileira contemporânea. A abordagem dos contextos de surgimento desse organismo oferece elementos para entender como as atuais instituições são herdeiras de corporações inscritas historicamente na tradição universitária em todo o mundo.

\subsubsection{Universidades da Europa: o surgimento de modelos}

As bases da universidade que conhecemos hoje remonta à Idade Média, quando foram fundadas as primeiras grandes universidades, entre elas: a Universidade de Bolonha, na Itália, no século XI (1088); a Universidade de Oxford, na Inglaterra, também no século XI (aproximadamente em 1096); e a Universidade de Paris, na França, no século XII (aproximadamente em 1170).

A universidade medieval tinha duas características importantes: sua organização e seu currículo. A estrutura foi influenciada por corporações existentes de artesãos e artífices. As primeiras universidades foram fundadas principalmente por estudantes, responsáveis por sua organização, pelo estabelecimento de regras e regulamentos e pela contratação de professores. Segundo Budd (1998), os estudantes criaram um meio de proteção para 
si mesmos, tanto com relação ao corpo docente como em relação às forças externas, isso quer dizer que ao se organizarem em um grupo coeso, tinham poder de negociação com os senhores de terras, bem como conseguiam estabelecer e influenciar o cumprimento de regras a serem seguidas pelo corpo docente.

Oliveira (2006, p. 73), ao se basear nos estudos de Verger, rastreia três origens diferentes para as universidades: "podemos definir as origens dessa corporação de ensino a partir de suas relações com o poder, de suas relações com as escolas anteriores e em função das lutas entre as gentes de saberes com as demais pessoas do local onde estavam localizadas".

As universidades se desenvolvem, de certa forma espontaneamente, como desdobramentos de escolas preexistentes, por exemplo, o ocorrido com as universidades de Bolonha, Paris e Oxford. Em seguida, surgem universidades a partir da secessão com outra mais antiga, por exemplo, a Universidade de Cambridge, originada da separação da Universidade de Oxford, em 1208, reflexo do embate contra autoridades locais. Para Oliveira:

Sua organização refletia a da universidade "mãe". Como as universidades "espontâneas", essas universidades nascidas por migração funcionavam muitas vezes longamente de fato antes de receberam uma bula de fundação e seus primeiros estatutos oficiais [sic]. (OLIVEIRA, 2006, p. 74)

Além dessas duas categorias de universidades, existiram outras "criadas" por autorização papal, por meio de bula, ou pelo imperador, por meio de carta de fundação. Esses documentos definiam seus estatutos e privilégios. Para Oliveira, essas universidades significam que:

[...] papas e soberanos não se contentam em tolerar ou encorajar o desenvolvimento espontâneo de universidades nascidas antes de tudo do desenvolvimento intelectual do século XII, mas que empreendem eles mesmos a criação de universidades, tendo tomado consciência do papel que elas podiam desempenhar ao colocar à disposição da Igreja ou do Estado um pessoal intelectualmente qualificado. Significava reconhecer na formação universitária, além de seu valor cultural e de seu prestígio, uma utilidade prática e um alcance político. (OLIVEIRA, 2006, p. 75) 
Essas autoridades, ao criarem uma universidade, mantinham as bases que sustentavam seu poder, uma vez que tais instituições não só proveriam os quadros administrativos, como formariam "defensores" do governo.

Em razão do grande poder da Igreja Católica nesse período, as universidades recebiam uma autorização papal para funcionarem. A essas instituições era concedido o título de studium generale ${ }^{1}$, que certificava seu status de excelência.

O desenvolvimento das cidades, a partir da Idade Média, propiciou igualmente o advento das universidades. Segundo Souza:

[...] o desenvolvimento das cidades foi um passo importante para o surgimento das universidades medievais. Com o desenvolvimento das técnicas agrícolas e o relaxamento das obrigações senhoris, os homens do campo estavam mais disponíveis e eram atraídos pelas cidades em desenvolvimento, as quais acenavam com novas perspectivas sociais, econômicas e políticas. (SOUZA, 1996, p. 42)

Essas cidades que se tornam centros comerciais parecem ver vantagens variadas em ter uma universidade nas redondezas:

Estavam ainda interessados em manter os filhos dos cidadãos que haviam escolhido a vocação intelectual nas universidades locais. Deste modo, depressa reconheceram a vantagem de uma aliança sólida com as universidades, empenhando-se então em obter o controlo destas. Nas cidades-estado, os professores começaram, cada vez com mais frequência, a receber salários dos municípios, e o controlo da universidade passou a pertencer ao funcionalismo público. (RÜEGG, 1996a, p. 18, apud, FERREIRA, 2009, p. 98)

Para Verger (1999), por volta do século XIV, os studia generalia tinham forte influência do modelo bolonhês, ou seja, os estudantes estavam envolvidos na organização e gestão da universidade, e as principais disciplinas eram o Direito Civil e o Direito Canônico. Para o autor, a situação no norte da Europa era diferente:

Os studia generalia eram ali pouco numerosos e o modelo parisiense, imitado com bastante fidelidade em Oxford e em Cambridge, afirmava-se aqui sem rival. Este modelo era aquele da "universidade de mestres", quer dizer, uma federação de escolas onde cada professor conservava plena autoridade sobre seus próprios estudantes e onde todos os órgãos de

1 A expressão pode ser traduzida como "estudos gerais", mas na realidade era o termo que designava as universidades na Idade Média, podia designar o local em si, como também as disciplinas ministradas. 
direção da universidade estavam nas mãos dos mestres eleitos por seus pares. Contudo, o essencial situava-se sem dúvida, mais ainda, na diferença da orientação intelectual. Nas escolas parisienses e inglesas, com efeito, o ensino do direito ocupava apenas um lugar limitado e tratava-se, sobretudo, do direito canônico. (VERGER, 1999, p. 85-86)

Para Cunha (2006, p. 15), o aumento do número de universidades até o século XV fez com que o corpo discente dessas instituições fosse mais local "diminuindo o sentimento de desenraizamento que dava a base subjetiva para a reivindicação da autonomia dos primeiros séculos". Para o autor, a diminuição da internacionalização das universidades juntamente à "sua manutenção pelo poder político foi fatal para sua autonomia" (CUNHA, 2006, p. 16). A partir do século XV, as universidades passam a ser cobradas a formarem profissionais que estariam a serviço do Estado, em face à nova ordem política de estabelecimento e fortalecimento dos Estados nacionais, em desenvolvimento.

Para Ferreira (2009, p. 100), o século XVII vê surgir as escolas especializadas, tais como as de Cirurgia, Medicina Veterinária, Agricultura. Já no século XVIII, as universidades começam a ministrar conhecimentos práticos, com ênfase nas profissões especializadas. Ainda para Ferreira, "a Revolução Industrial e a consolidação do modo de produção capitalista impuseram a necessidade de formação técnica para ajustar-se a nova divisão social do trabalho" (2009, p.100).

As revoluções burguesas usaram a filosofia liberal, que se constituiu como ideologia da burguesia em ascensão e do modo de produção capitalista (FERRARO, 2009), como justificativa para suas pautas. Ferraro $(2009$, p. 309) defende que "o capitalismo e sua ideologia, o liberalismo, mantiveram desde o início uma relação ambígua e até conflituosa com a escola, porquanto esta, se por um lado se afigurava necessária, por outro despertava temor".

Baseado no conceito de liberdade, o liberalismo apresenta uma série de características que foram mais ou menos destacadas dependendo da situação política e econômica do momento. As revoluções do século XVII também trouxeram mudanças para os contextos universitários de diferentes países, proporcionando reformas universitárias implementadas no século XIX, o que fez surgir três modelos 
de universidade que passam a ser referência para diversas instituições em vários países.

\subsubsection{Modelo francês (ou napoleônico): caráter instrumental}

A Revolução Francesa (1789-1799) extinguiu as universidades existentes até então e reorganizou o ensino superior "como um sistema de escolas superiores autárquicas organizadas como um serviço público" (FERREIRA, 2009, p. 101).

Para vislumbrarmos o contexto da época é preciso entender que vários fatores contribuíram para a deflagração da Revolução Francesa. Esses fatores remetem à exclusão da burguesia do poder político, passando por uma crise econômica do governo francês decorrente do apoio da França à Revolução Americana, somada a problemas nas safras, o que gerou fome da população mais pobre. Junte-se a isso a situação de pobreza das massas camponesas, a qual tornava cada vez mais difícil a manutenção de um sistema feudal anacrônico e oneroso. A incapacidade da monarquia francesa em lidar com as pressões políticas e sociais aumentou a inquietação e incitou a revolução, que teve apoio dos ideais de filósofos iluministas na França.

Para Silva (2007), o início de um sistema educacional francês público, universal e laico tem suas bases na Queda da Bastilha e na revolução caracterizada por ideais do lluminismo. Assim, "liberdade, igualdade e fraternidade" passam a ser o lema de uma nova ordem social, que ia contra a intolerância religiosa e a ligação entre o Estado Absolutista e a Igreja.

Esse sistema educacional tem suas bases nas ideias de Condorcet que, ao ser nomeado presidente do Comitê de Instrução Pública da Assembleia Legislativa Francesa, elabora um relatório em que constam os princípios para um sistema de ensino público. Para Condorcet, esta era a oportunidade de caminhar para a igualdade de oportunidades de acesso à escola e, assim, de diminuir as desigualdades sociais. O objetivo era: 
[...] obter progressivamente a minimização das desigualdades produzidas pelo artifício humano, pela concomitante promoção da única desigualdade estrutural, e portanto, legítima: a desigualdade de talentos - dos dons, das aptidões, dos potenciais, enfim, das capacidades de cada um perante os demais. A preparação cultural acentuaria a força meritória dos mais capazes, o que era, por si, um elemento corretor dos próprios embaraços de uma sociedade liberal, que tinha em mente assegurar, com firmeza, o direito à propriedade, e, portanto, à herança. (BOTO, 2003, p. 742)

Condorcet defendia a escolarização laica, gratuita, pública, para ambos os sexos e para todos, ou seja, uma educação universalizada. Ele apresenta seu Plano de Instrução Nacional para a Assembleia Legislativa em 1792, porém as ideias contidas em seu relatório não foram postas em prática, mas se tornaram referência para o debate sobre educação. Entretanto, o relatório traz as bases de uma rede de educação pública, que seria custeada pelo Estado, mas sem estar diretamente submetida a este, uma vez que o $5^{\circ}$ grau de instrução proposto por Condorcet seria o da Sociedade Nacional das Ciências e das Artes, instituição a ser responsável por "supervisionar e direcionar instituições de ensino, para cuidar do desenvolvimento da ciência e das artes, para coletar, incentivar, aplicar e disseminar descobertas úteis"2 (CONDORCET, 1989, p. 25).

Silveira e Bianchetti (2016, p. 86) apontam, entretanto, que a reforma napoleônica da educação, iniciada com a nomeação do conde de Fourcroy para o Ministério da Instrução Pública em 1802, foi um instrumento de "coerção, controle social e construção de hegemonia em torno da ideologia do Estado". Em 1806, Napoleão decreta a criação da Universidade Imperial, instituição encarregada pelo ensino em todo império francês, em todos os níveis (aqui cabe notar que a ideia de um organismo central que seria responsável pelos níveis de ensino já estava presente no relatório de Condorcet).

Essa lei, que dispõe sobre a criação da Universidade Imperial, será complementada pelo decreto de 1808 , em que constam as bases da educação. O artigo 38 (FRANÇA, 1808, p. 06) propõe que as escolas tomarão por base os preceitos da religião católica, a fidelidade ao imperador e à monarquia imperial, deixando claro

2 "instituée pour surveiller et diriger les établissements d'instruction, pour s'occuper du perfectionnement des sciences et des arts, pour recueillir, encourager, appliquer et répandre les découvertes utiles." 
que a função da educação seria "formar, para o Estado, os cidadãos ligados à sua religião, a seu príncipe, ao seu país e sua família" ${ }^{3}$. Por essa razão, Hobsbawm (2011) afirma que Napoleão hierarquizou as instituições públicas, desde as cortes até às escolas, passando pela universidade.

Assim, a Universidade Imperial confere caráter centralizador à instrução do país, bem como reflete um contexto, que, segundo Silveira e Bianchetti (2016, p. 87), seria:

[...] uma concepção educacional fundamentada nas necessidades práticas da classe dominante, sendo um dos exemplos mais antigos de instrumentalização da universidade pelo Estado, exercida por mediação da legislação, controle financeiro e de nomeações em todo território nacional, com vistas à modernização da sociedade, à construção de uma identidade nacional e à (con)formação da classe trabalhadora.

Assim, esse modelo francês passa a pregar uma universidade com caráter instrumental e utilitário, pois esta acaba se tornando a provedora de mão de obra, ou seja, preencheria os quadros técnicos, passando a ter como objetivo a ordem e o progresso daquela sociedade.

Para Ferreira (2009, p. 101):

As ideias de Napoleão Bonaparte sobre universidade influenciaram significativamente sua organização e sua finalidade social. A universidade imperial por ele pensada deveria constituir-se como serviço público do Estado, estar ideologicamente subjugada ao poder e a serviço da conservação da ordem social. A pesquisa, nessa concepção, ficou relegada a um patamar inferior. O papel da universidade nesse período objetivou formar profissionais (professores, juristas, médicos, etc.) e preparar para concursos que dão acesso a funções públicas. O ensino constitui-se de um caráter essencialmente profissional. As faculdades tenderam a organizar-se isoladamente, distanciando-se do modelo de universidade orgânica.

Muscará (2012, p. 15) corrobora essa ideia:

[...] o ensino superior assumiu um caráter marcadamente profissionalizante e a produção de conhecimento teve forte dependência de políticas impulsionadas pelo poder. Isto implicou algumas consequências, como a independência das faculdades em detrimento da instituição como um todo e a criação de escolas politécnicas ou formação de professores fora da universidade.

3 "qui tendent à former, pour l'état, des citoyens attachés à leur religion, à leur prince, à leur patrie et à leur famille" 


\subsubsection{Modelo alemão: ênfase na pesquisa}

Humboldt, influenciado pelas ideias do filósofo Johann Gottlieb Fichte e do teólogo e filósofo Friedrich Schleiermacher, imaginou uma universidade em que ensino e pesquisa se realizam tornando possível uma educação humanista completa dos estudantes. As ideias de liberdade de aprender, liberdade de ensinar, recolhimento e liberdade do pesquisador e do estudante foram postas em prática com a fundação da Universidade de Berlim.

Para Ferreira (2009), Humboldt destacava o papel fundamental da pesquisa enquanto articuladora entre ensino e formação. Para a autora, "esse modelo priorizava a formação geral, científica e humanista mediante a totalidade e a universalidade do saber", o que, de certa maneira, tem relação com o conceito de formação cultural, entendida como processo de aprimoramento cultural dos novos contingentes universitários. Para tal, a universidade deveria ser autônoma, apesar da dependência econômica do Estado" (p. 101-102).

Nas palavras do próprio Humboldt:

O que, portanto, chama-se de instituições científicas superiores é, desconectado em todos os sentidos do estado, nada mais do que a vida intelectual das pessoas a quem o lazer externo ou o desejo interior leva à ciência e à pesquisa. [O Estado] Deve certificar-se de: 1. preservar sempre a atividade em sua vitalidade mais viva e robusta; 2 . não permitir que ela diminua, manter pura e firme a separação entre instituições superiores e escola (não apenas entre as de aspecto teórico geral, mas também, e especialmente, entre as de variação prática). (HUMBOLDT, 1810)

Silveira e Bianchetti (2016, p. 83) apontam que Humboldt idealizou a universidade alemã conciliando "liberdade de ensino e intervenção estatal", o que geraria uma tensão entre a "necessidade de compatibilizar a expansão indefinida da liberdade de pensar com o ordenamento de caráter político, jurídico e escolar".

Ainda para os autores, percebe-se o ideal liberal nesse modelo de universidade, uma vez que o Estado deveria proteger a liberdade acadêmica, em contraponto a conflitos de interesses de classes, ao mesmo tempo em que controlaria os currículos sem interferir na liberdade individual de ensinar e aprender. 
Por essa concepção, o ensino e a pesquisa foram considerados funções da vida universitária, mas a ideia unitária da Universidade começou a ser diluída no trabalho isolado de um conjunto de faculdades, escolas e organizações (MUSCARÁ, 2012).

\subsubsection{Modelo inglês: ênfase na educação liberal}

$\mathrm{Na}$ Inglaterra, segundo Ferreira (2009, p. 104), o ideal universitário "partia do princípio da formação não utilitária e da formação integral mediante um método de ensino praticamente individual que se desenvolvia pelo regime de internato, em pequenos colégios e no sistema tutorial".

Em 1850, uma Comissão Real foi designada para investigar as duas antigas universidades de Oxford e Cambridge. O relatório da comissão resultou na promulgação de novos estatutos para Cambridge, que determinaram estruturas administrativas para a universidade.

Em 1833, Oxford se destaca nas discussões religiosas, então surge o Movimento Oxford, do qual fazia parte John Henry Newman, cujo livro The idea of university (1852) torna-se referência para o debate sobre universidades. Newman funda, em 1854, a Universidade Católica da Irlanda (atual University College Dublin).

Ferreira (2009, p. 104) aponta que Newman priorizava "a formação do caráter e da personalidade. [...] A universidade seria um locus do ensino e do saber universal, ou seja, de difusão e de extensão".

Newman lutou por um equilíbrio adequado entre objetivos utilitários e liberais, procurando preservar o que havia de melhor nos cursos universitários mais antigos, mas também estava ansioso para que sua universidade respondesse às necessidades, aos desenvolvimentos e ao crescente campo de conhecimento de seu próprio tempo:

Newman reconheceu os benefícios que uma universidade poderia dar à comunidade em que estava situada, iniciando uma série de palestras públicas a serem ministradas pelos professores da Universidade Católica. 
Antes de qualquer outro colégio universitário no país, ele lançou um sistema de palestras noturnas para estudantes que trabalhavam durante o dia. (UNIVERSITY COLLEGE DUBLIN, 2019)

Newman defendia a educação liberal, a qual, para ele, "justifica-se pelo seu próprio bem e não por outros fins" (PEREIRA, s/d, p. 70). Newman definia Educação Liberal como o:

[...] processo de treinamento, pelo qual o intelecto, em vez de ser formado ou sacrificado para algum propósito particular ou acidental, algum ofício ou profissão específica, ou estudo ou ciência, é disciplinado por si mesmo, para a percepção de seu próprio objeto e por sua própria cultura mais elevada. (NEWMAN, 2008, p. 181)

Para ele, o objetivo da universidade estava em ajudar os estudantes nesse processo de treinamento, estabelecendo padrões de acordo com suas capacidades. Pereira salienta que Newman (s/d, p. 71) "associava a educação liberal com a educação do homem socialmente livre, aquela sem interesses pragmáticos e não vinculada a classe social".

Pereira complementa que ao afirmar que o conhecimento contém sua própria recompensa, Newman oferecia, assim, uma formação que preparava os estudantes para:

[...] elevar o tom intelectual da sociedade, cultivar a opinião pública, purificar o gosto nacional, fornecer verdadeiros princípios ao entusiasmo popular e objetivos fixos à aspiração popular, dar alargamento e sobriedade às ideias da época, facilitar o exercício do poder político e o refinamento das relações da vida privada. É a educação que dá ao homem uma visão clara e consciente de suas próprias opiniões e julgamentos, uma verdade em desenvolvê-los, uma eloquência em expressá-los e uma força em instá-los. Ensina-o a ver as coisas como são, a ir direto ao ponto, a desenredar uma meada de pensamento, a detectar o que é sofístico e a descartar o que é irrelevante. Isso o prepara para preencher qualquer cargo com credibilidade e para dominar qualquer assunto com facilidade. Mostra-lhe como se acomodar aos outros, como se lançar ao estado de espírito deles, como apresentar o seu próprio estado, como influenciá-los, como chegar a um entendimento com eles, como suportá-los. (NEWMAN, 2008, p. 206-207) ${ }^{5}$

4 This process of training, by which the intellect, instead of being formed or sacrificed to some particular or accidental purpose, some specific trade or profession, or study or science, is disciplined for its own sake, for the perception of its own proper object, and for its own highest culture.

5 It aims at raising the intellectual tone of society, at cultivating the public mind, at purifying the national taste, at supplying true principles to popular enthusiasm and fixed aims to popular aspiration, at giving enlargement and sobriety to the ideas of the age, at facilitating the exercise of 
Pereira salienta que a crítica que se faz aos ideais de Newman é com relação à inadequação de seus propósitos a uma época que então via nascer o modelo alemão de universidade.

Para Muscará (2012, p. 13), diferentemente da perspectiva da universidade alemã, em Oxford e Cambridge "não é a pesquisa que constitui a missão dos estudos, mas acima de tudo, a aprendizagem". Nessa concepção, a preservação do conhecimento é a característica fundamental da atividade universitária. O autor ressalta que para esse modelo de universidade não é suficiente transmitir conhecimento, "devemos criar hábitos de disciplina e solidariedade, refinar a capacidade de discernimento, o senso de moderação, a consciência do dever [...] A Universidade inglesa tem como objetivo a formação do cavalheiro" (MUSCARÁ, 2012, p. 14).

Para Ferreira (2009, p. 106):

\begin{abstract}
A concepção de ensino superior marcada pela fé na ciência e na técnica como realizações da razão e o papel significativo da universidade na consolidação dos Estados-nação manifestaram-se como expressões da narrativa moderna que entraram em crise no século $X X$, a partir da emergência de uma nova narrativa - a do mercado.
\end{abstract}

\title{
2.1.5 Modelo estado-unidense: ênfase na ideia de progresso
}

As primeiras instituições de ensino superior estado-unidense foram fundadas durante a colonização dos Estados Unidos por grupos religiosos nos séculos XVII e XVIII e incentivadas pela metrópole. Essas primeiras faculdades se espelhavam nas instituições inglesas, tinham base religiosa e eram direcionadas à formação do clero puritano.

political power, and refining the intercourse of private life. It is the education which gives a man a clear conscious view of his own opinions and judgments, a truth in developing them, an eloquence in expressing them, and a force in urging them. It teaches him to see things as they are, to go right to the point, to disentangle a skein of thought, to detect what is sophistical, and to discard what is irrelevant. It prepares him to fill any post with credit, and to master any subject with facility. It shows him how to accommodate himself to others, how to throw himself into their state of mind, how to bring before them his own, how to influence them, how to come to an understanding with them, how to bear with them. 
Tendo como referência as instituições europeias e formando quadros administrativos para o Estado e para o clero, bem como atendendo a interesses das elites locais, as instituições estado-unidenses eram malvistas pela população de uma maneira geral devido à mentalidade cultivada de que a América seria "the land of opportunities" e o seu povo "self-made man"6 (FERREIRA, 2009, p. 109). Silveira e Bianchetti (2016) ressaltam que a Declaração de Independência e a Declaração de Direitos materializaram os ideais liberais das revoluções burguesas e "mediante essa ideologia, vislumbrou-se a educação superior a partir de um caráter imediato e útil a toda a nação, relegando o chamado academicismo" (FERREIRA, 2009, p. 109).

Ainda no século XIX, o Morrill Act $^{7}$ atendia à demanda de movimentos políticos que pediam a criação de faculdades de agricultura. Essa lei previa a concessão de terras para a criação de faculdades de agricultura e artes mecânicas ${ }^{8}$. Essas instituições deviam oferecer serviços para toda a população:

\begin{abstract}
Dessa forma, o paradigma da universidade mudou em um duplo sentido: a) os estudos científicos e liberais-clássicos foram substituídos por lições práticas e b) as instituições começaram a se preocupar em oferecer programas de estudos ligados às necessidades da comunidade. Desta forma, o estudo e o trabalho foram considerados como dois meios complementares na formação integral das pessoas. No saber-fazer, o homem demonstra sua vocação de serviço para os outros e justifica sua atividade teórica, pois o trabalho é humanizado quando o homem sabe por que e para o que ele faz as coisas. (MUSCARÁ, 2012, p. 16)
\end{abstract}

6 A Declaração de Independência dos Estados Unidos (NATIONAL ARCHIVES, 1776) expressa que "todos os homens são criados iguais" com direito a "vida, liberdade e a busca da felicidade", daí surge um conjunto de ideais (democracia, direitos, oportunidade e igualdade) em que a liberdade inclui oportunidade de prosperidade e sucesso, alcançado pelo trabalho. Nasce daí a concepção de que os Estados Unidos seriam a terra das oportunidades e "self-made man" é aquele que tem sucesso por seus próprios méritos e esforços.

7 Morrill Act é um conjunto de leis pelas quais o governo federal dos Estados Unidos concederia terras públicas aos estados federados para a construção de Escolas Superiores de Agricultura, Mecânica e Táticas Militares. O primeiro decreto é assinado em 1862, durante a Guerra Civil Americana. O segundo decreto é de 1890 e expande o modelo previsto no primeiro decreto.

8 Verger (1999, p. 39) traz o conceito medieval de artes mecânicas, ou seja, um "saber-fazer excessivamente técnico, implicando trabalho manual e contato imediato e degradante, senão servil, com a matéria", que teria como contraponto o conceito de artes liberais. Em seu texto Information Literacy as a liberal art, Shapiro e Hughes (1996) trazem a ideia de information literacy como uma arte liberal, ou seja, algo que permita aos sujeitos pensarem criticamente sobre a sociedade, a partir de processos de leitura crítica da informação. Ao se pensar a information literacy por essa concepção mais ampla de uma arte liberal, entende-se que essa noção é essencial para o futuro da democracia, e ainda defendem que para alcançarmos uma sociedade livre e humana, abolindo a desigualdade, deveríamos contribuir para a liberdade pelo avanço do conhecimento dos cidadãos, pela democratização da educação. 
Para Budd, Morrill Act teria um efeito considerável no futuro do ensino superior em muitas frentes. Para ele, projeto de lei dava um impulso formal à educação das áreas agrícola e mecânica. As oposições ao projeto de lei foram desde o questionamento da constitucionalidade pelos estados do sul, ceticismo do ensino superior, além da queixa de que os estados do norte, mais populosos e menos agrários, se beneficiariam desproporcionalmente.

Com a aprovação da lei, os estados seguiram diferentes caminhos: alguns criaram faculdades de agricultura e artes mecânicas que foram incorporadas por instituições existentes; alguns delegaram a responsabilidade para as universidades estaduais existentes, outros criaram faculdades que passaram a competir com as universidades por financiamento estatal; outros ainda fundaram universidades estatais que incluíam as faculdades de agricultura e artes mecânicas. Para Budd (1999, p. 36), "em alguns casos, a designação de concessão de terras criou algumas instituições aparentemente anômalas".

Budd ainda afirma que a aprovação do decreto de 1890 repercute até hoje: por meio dele ficou estipulado que a nenhum estudante poderia ser negada a admissão em uma instituição de concessão de terras com base na raça. "A alternativa oferecida foi o estabelecimento de instalações separadas, mas iguais. Dezessete estados decidiram seguir esse caminho"9 (BUDD, 1999, p. 36).

Ainda no século XIX, um evento importante foi a fundação da Universidade Johns Hopkins, em 1879, cuja premissa consistia em maior atenção à pesquisa. Esta universidade teve influência do modelo alemão, e dos princípios de liberdade de ensinar e liberdade de aprender. Para Budd, deu-se menor ênfase nas aulas e no professor e mais na investigação pessoal do aluno, embora ainda apresente autores que sustentam que o "ensino superior americano perverteu o ideal alemão e optou por prestar atenção à prática e não à teoria acadêmica" (BUDD, 1999, p. 37).

9 The alternative offered was the establishment of separate but equal facilities. Seventeen states decided to go that route. 
Até então, a universidade era frequentemente o produto de uma personalidade, geralmente seu reitor. Durante esse período em que o crescimento foi possível em algumas instituições, as próprias universidades foram transformadas por esses indivíduos de forte vontade. Assim, algumas instituições assumiram a liderança no estabelecimento da universidade como não apenas o lugar do ensino e da aprendizagem, mas como uma força social crescente nos Estados Unidos:

[...] essa transformação estava apenas começando no final do século XIX, no entanto. A liderança assumida pelo mais agressivo dos reitores não foi seguida por todos os administradores educacionais. Muitos eram complacentes e satisfeitos com o mundo educacional como ele era. Além disso, o público não estava pronto para atribuir ao ensino superior o respeito e a aceitação como força integral na vida de muitas pessoas que viriam mais tarde ${ }^{10}$. (BUDD, 1999, p. 39)

No início do século $X X$, vê-se o aumento de instituições de ensino superior junto à crescente organização burocrática de faculdades e universidades. Assim, a universidade do início desse século, era formada não só pelo corpo docente e discente, mas também por toda uma infraestrutura que incluía as instalações físicas, laboratórios e um orçamento a ser administrado. Budd aponta que cada vez mais professores passaram a possuir títulos de doutorado e mais instituições estabeleciam programas de doutorado. Alguns reclamaram que o aprendizado estava dando lugar à concessão de diplomas. Isso significa que as universidades estavam se tornando instituições burocráticas e hierárquicas, em que os títulos sobrepunham o ensino, como símbolos da superespecialização.

Nos Estados Unidos criou-se uma diversidade de instituições de ensino:

universidades de ponta (núcleo do progresso), colégios residenciais, instituições parcialmente especializadas, universidades que focavam 0 ensino noturno, instituições confessionais, públicas e privadas. As pesquisas científicas seriam promovidas pelas universidades de ponta que deveriam socializar os resultados com as demais instituições. (FERREIRA, 2009, p. 110-111)

10 This transformation was just beginning in the late nineteenth century, though. The lead taken by the most aggressive of the presidents was not followed by all the educational world as it had been. Also, the public was not quite ready to ascribe to higher education the respect and the acceptance as an integral force in many people's lives that would come later. 
Para Silveira e Bianchetti (2016, p. 88), o modelo estado-unidense enfatiza o progresso, "fazendo a aspiração dos indivíduos da sociedade convergir para o saber que interessa ao desenvolvimento econômico". O grande número de cursos de graduação e de pós-graduação seria uma maneira de conciliar os aspectos de ensino e pesquisa, e serviço à comunidade para o funcionamento da sociedade.

Após a Segunda Guerra Mundial, alguns eventos trouxeram mudanças para o ensino superior nos Estados Unidos. Em 1948, um decreto, conhecido como G.I. Bill of Rights, estabelecia serviços e benefícios para os veteranos de guerra, entre eles crédito educacional, o que possibilitou a milhões de pessoas que serviram nas Forças Armadas frequentarem faculdades e universidades.

Além disso, a corrida espacial mostrou a preocupação do governo federal em responder a qualquer desafio potencial à segurança global. Assim, o governo investe em educação em todos os níveis. Segundo Budd, essa infusão de dinheiro na educação proporcionou que as instituições fizessem algumas reformas. Esse investimento na educação foi reforçado ainda na década de 1960 com a Lei de Ensino Superior, que previa o desenvolvimento curricular, bolsas de estudo para os vários níveis de estudos e melhorias nas bibliotecas.

Com o investimento em educação, a facilidade de assistência financeira, o aumento de matrículas, as instituições foram pressionadas. Como relata Budd (1999, p. 44):

\begin{abstract}
Novos edifícios, adições a bibliotecas ou novos edifícios de bibliotecas. Havia também a necessidade de professores para educar o número crescente de alunos. Mais programas de doutorado foram instituídos em mais universidades. Em um curto período, uma geração de professores foi educada, contratada e arrendada. De modo algum todos esses professores tinham um forte compromisso com a pesquisa. A complexidade das instituições dos anos 60 levou Clark Kerr a se referir a elas como multiversidades. Ele observou que, diferentemente da universidade medieval, não há um único grupo unificado de estudantes que compartilhem objetivos intelectuais e acadêmicos para o eventual uso de sua educação ${ }^{11}$.
\end{abstract}

11 New buildings, additions to libraries, or new library buildings. There was also the need for faculty to educate the increasing number of students. More doctoral programs were instituted at more universities. In a short period a generation of faculty were educated, hired, and tenured. By no means did all of these faculty have a strong commitment to research. The complexity of the institutions of the '60s prompted Clark Kerr to refer to them as multiversities. He observed that, 
A partir da segunda metade da década de 1960, os Estados Unidos entram em recessão econômica, o que leva as instituições a reverem algumas medidas, entre elas a criação de centros de estudos e institutos de pesquisa. $O$ financiamento público é limitado e essas instituições passam a ter um comportamento cada vez mais competitivo. Segundo Budd, elas competem por estudantes, professores e dinheiro - que passa a vir de várias fontes, desde fontes governamentais (basicamente financiando pesquisa) a fundações e doações. Essa "competitividade significa que muito mais instituições passaram a adotar a pesquisa como missão, independentemente de estar de acordo com o restante de sua missão institucional"12 (BUDD, 1999, p. 45).

Há também uma demanda crescente pela prestação de serviços nunca antes oferecidos ou pelos serviços tradicionais oferecidos por novos meios. Assim, para suprir as necessidades da comunidade, foram criados os two-year colleges, modalidade de cursos de dois anos, geralmente profissionalizantes, de nível superior.

Para Ferreira (2009, p. 112), esse sistema tem possibilitado maior acesso à educação pós-secundária, porém prevalece uma expressiva distinção entre as universidades tradicionais "que realizam pesquisa e ensino que continuam atendendo a uma elite, e as IES que oferecem cursos curtos e profissionalizantes para uma massa de indivíduos". Essa ideia e o conceito de multiversidade de Kerr possibilitam o debate sobre a distinção entre ensino universitário e ensino superior.

Muscará (2012, p. 18) vê a evolução do sistema estado-unidense como uma "combinação de estabilidade institucional conservadora, de um lado, e adaptação a novas tendências, de outro. [...] Reformas institucionais em larga escala têm sido raras".

unlike the medieval university, there is no single unified group of students who share intellectual and academic goals for the eventual use of their educations.

12 This competitiveness means that many more institutions have come to adopt research missions regardless of whether that is in concert with the rest of their institutional mission. 


\subsubsection{Universidade no Brasil: amálgama de modelos}

A educação no período colonial foi marcada pela presença da Companhia de Jesus, cujo objetivo prioritário era converter os "índios e dar apoio religioso aos colonos" (CUNHA, 1980, p. 25).

O projeto jesuítico no Brasil implicou a fundação de colégios em várias regiões do país. Segundo Trindade (2008, p. 563):

\footnotetext{
Embora sua principal tarefa fosse a conversão dos índios, a fundação de colégios tornou-se também uma prioridade para a ordem. Neste campo adotaram seu método pedagógico próprio: a Ratio Studiorum.
}

Ratio studiorum se caracterizou como um sistema de ensino que estabeleceu metodologias e conteúdos em razão de padronizar procedimentos e decisões, garantindo o rigor do ensino jesuítico (FERREIRA; BITTAR, 2012).

Os colégios jesuíticos dividiam o ensino em quatro graus: curso elementar, curso de humanidades, curso de artes e o curso de teologia. Assim, o curso elementar pretendia ensinar a ler, escrever, contar e a doutrina católica. O curso de humanidades, ministrado em latim, envolvia o ensino de gramática, retórica e das humanidades. O curso de artes, ou de ciências naturais ou filosofia, era responsável pelo ensino de lógica, física, matemática, ética e metafísica. O curso de teologia tratava de teologia moral e a teologia especulativa, conferindo o grau de doutor ao fim de quatro anos (CUNHA, 1980; TRINDADE, 2008).

Segundo Cunha (1980), os cursos de artes dos colégios brasileiros orientavam-se pelo mesmo plano pedagógico europeu e eram preparatórios para os cursos da Universidade de Coimbra. Apesar disso, o "valor" atribuído ao grau do Colégio da Bahia, por exemplo, não era o mesmo do colégio de Évora. Assim, inicia-se, na segunda metade do século XVII, um movimento de reivindicação de equivalência dos graus concedidos pelos dois Colégios, ao que a Universidade de Coimbra se opôs.

Para Trindade, a elite brasileira seguia um caminho: frequentava os colégios jesuítas presentes em várias regiões do país e, terminado o curso, buscava formação 
superior em Portugal. A afirmação é corroborada por Fávero (2006, p. 20) ao dizer que "os alunos graduados nos colégios jesuítas iam para a Universidade de Coimbra ou para outras universidades europeias, a fim de completar seus estudos". Já o clero tinha mais opções no país, uma vez que podia procurar a formação no colégio da Bahia, bem como buscar a formação superior em um dos seminários de Pernambuco, Minas Gerais e Rio de Janeiro.

Entretanto, a fragmentação do sistema montado pela Ordem é consolidada, a partir de 1759, quando os padres jesuítas foram expulsos de Portugal e do Brasil e expropriados de todas as suas propriedades.

Segundo Cunha (1980, p. 36), "a expulsão jesuíta não correspondeu à hegemonia de alguma outra ordem religiosa que viesse repetir-lhes as práticas, mas, sobretudo, deu lugar a novos currículos, novos métodos de ensino, nova estrutura da educação escolar". Para o autor, a expulsão dos jesuítas pelo Marquês de Pombal foi uma tentativa de "reforçar o poder do Estado", como meio de atingir objetivos de política econômica que permitisse certa independência da Inglaterra. A política pombalina, tentativa de industrialização de Portugal, nos moldes ao que estava acontecendo na Inglaterra, buscava reverter ao país os requisitos econômicos para uma situação de dominação. Para Cunha (1980, p. 39-40), a efetivação dessa política econômica se daria por meio de três objetivos básicos, a saber:

\footnotetext{
Primeiro, o incentivo às manufaturas na metrópole. [...]. Segundo, o incentivo à acumulação de capital público e privado, [...]. Terceiro [...], a substituição das ideologias orientadas para uma sociedade feudal, para outras, orientadas para uma sociedade capitalista.
}

Nesses termos, o modelo jesuítico contrariava a perspectiva das referidas reformas, com reflexos nos sistemas educativos vigentes.

Trindade (2008, p. 565) explica que as reformas pombalinas foram sentidas no Brasil por meio da Universidade de Coimbra, pois tiveram "influência na Colônia na organização do Seminário de Olinda, fundado em 1798 e no Rio de Janeiro, onde os frades franciscanos criaram, no Convento Santo Antônio, em 1776, um curso de estudos literários e teológicos", que seguiam o modelo da universidade portuguesa. 
Para Cunha, os estatutos desses colégios combatiam a escolástica, bem como defendiam a monarquia e a religião católica.

Para Fávero (2006), havia a intenção de criação de uma universidade no Brasil na agenda da Inconfidência Mineira. Cunha (1980, p. 61) se pergunta "Que papel teve esse ensino superior na independência do Brasil?" Embora não se apresente otimista sobre os efeitos políticos do ensino do Seminário de Olinda, o autor admite que a pedagogia de então pode ter propiciado "a aceitação dessa ideologia, trazida ao Brasil pelas lojas maçônicas e pelos efeitos paradigmáticos da Revolução Francesa e da independência das colônias inglesas e espanholas na América".

Em 1808, o Brasil passa a ser a sede do Império Português, quando reage à invasão napoleônica e transfere a corte para o Rio de Janeiro. Essa mudança do poder metropolitano para o Brasil traz a necessidade de modificar o ensino superior da colônia até então, embora ainda estivesse dentro "dos marcos da dependência cultural aos quais Portugal estava preso" (CUNHA, 1980, p. 62).

Fávero (2006, p. 20) deixa claro que "mesmo como sede da Monarquia, o Brasil consegue apenas o funcionamento de algumas escolas superiores de caráter profissionalizante". Cunha (1980, p. 70) explica que:

$\{\ldots\}$ formou-se o núcleo do ensino superior sobre o qual veio a ser edificado o que existe até hoje, ligado a sua origem por ampliação e diferenciação. $O$ ensino superior atual nasceu, assim, junto com o Estado Nacional, gerado por ele e para cumprir, predominantemente, as funções próprias deste.

Mendonça (2000, p. 134) expõe que a formação de quadros técnicos a fim de suprirem as necessidades da corte estava relacionada à preocupação com a defesa militar da colônia, agora sede do governo. Assim, são criadas a Academia de Marinha e a Academia Real Militar, que formariam oficiais e engenheiros civis e militares. Em 1808, foram criados os cursos de anatomia e cirurgia e mais tarde 0 curso de medicina. Como se vê, a base do ensino superior no Brasil está fundada em escolas e faculdades isoladas, influenciadas pelo modelo napoleônico (CUNHA, 2017; SEVERINO, 2012). Baseado nesse modelo, D. João VI e seus conselheiros rejeitam a ideia de criar uma universidade proposta pelos comerciantes baianos, e 
apenas instituem cadeiras ou faculdades profissionais isoladas, o que faz com que os cursos de ensino superior tenham um caráter fragmentário que ainda deixa resquícios. Segundo Cunha (2007b, p. 19), a falta de integração em uma instituição universitária, evidenciada pela "especialização das faculdades na mera formação profissional", teve como resultante uma estreiteza cultural.

É no século XIX que a influência do positivismo pode ser vista no meio de médicos, engenheiros, oficiais do exército. Isso acontece em razão do retorno desses profissionais que foram estudar em Paris e da importação de livros dessas ciências, usados nas faculdades de então. Para Trindade (2008, p. 570), isso configura a "presença e o potencial mais visível da ciência aplicada (saúde pública, agricultura, engenharia, geologia)".

Ainda para o autor, o governo da República Velha priorizará o ensino profissionalizante e técnico no nível superior:

[...] mantendo-se fiel a tradição que vem desde o Reino Unido e do Império de uma formação superior utilitária e profissionalizante. Não obstante serem profissionalizantes, essas escolas superiores cumpriam também as funções de uma formação para a cultura geral, sob a influência da cultura européia, especialmente francesa. (TRINDADE, 2008, p. 570)

No início do século $X X$ foram fundadas algumas universidades no Brasil que, de acordo com Sguissardi (2011, p. 277), "respondiam pragmaticamente ao imediatismo das exigências do poder burocrático e das necessidades das elites detentoras dos poderes econômico, político e cultural".

Para Ferreira (2009, p. 157), isso permite associar a origem da educação superior no Brasil ao privilégio social, "cuja democratização iniciava e terminava nos limites da burguesia".

Diante da fundação dessas instituições, ficou claro que se tratava, sobretudo, da reunião de escolas superiores, o que Ferreira (2009) chama de universidade atomizada. Para Sguissardi (2011, p. 277), essas instituições se baseavam no modelo napoleônico em razão do enfoque na formação técnico-profissional: 


\begin{abstract}
Até então, em que pesem experiências isoladas que associavam o modelo profissional napoleônico a aspectos do modelo humboldtiano, sobressaem os traços do primeiro, seja pelo predomínio da formação técnico-profissional e pouca importância atribuída à investigação e produção de conhecimentos, seja, inclusive, no caso da URJ, pela simples aglutinação formal e respectivo isolamento físico das três unidades pré-existentes ao ato fundador da Universidade.
\end{abstract}

Para Cunha (2007a, p. 18), o decreto-lei de $1931^{13}$ que regularizava o ensino superior dava ao governo controle sobre essas instituições, "tradição que se mantinha desde o ato adicional de 1834, reforçada pela criação, em novembro de 1930, do Ministério da Educação, tendo Francisco Campos como primeiro titular". O estatuto difundia como objetivos do ensino universitário:

[...] elevar o nivel da cultura geral, estimular a investigação scientifica em quaesquer dominios dos conhecimentos humanos; habilitar ao exercicio de actividades que requerem preparo technico e scientifico superior; concorrer, emfim, pela educação do individuo e da collectividade, pela harmonia de objectivos entre professores e estudantes e pelo aproveitamento de todas as actividades universitarias, para a grandeza na Nação e para o aperfeiçoamento da Humanidade. (BRASIL, 1931)

Embora o estatuto difundisse esses objetivos, impunha uma organização do nível superior vinculada às faculdades e institutos, uma vez que exigia a existência de uma Faculdade de Direito, Faculdade de Medicina, Escola de Engenharia e Faculdade de Educação, Ciências e Letras para compor a universidade, tornando assim a faculdade a célula do ensino superior, de acordo com Cunha (2007a), consolidando uma estrutura hierárquica e controlada.

Cunha (2007a) complementa que a fundação da Universidade de São Paulo, em 1934, é uma tentativa de um novo modelo de universidade, com professores europeus, que deram início a um processo de institucionalização da ciência. Para Trindade (2008, p. 577), as universidades paulistas são uma resposta para a formação "de novas elites intelectuais, políticas e sociais".

Conforme Sguissardi (2011, p. 278):

Não haveria lugar para experiências inovadoras fora de controle e supervisão do Estado. O controle estrito e a ausência de autonomia são

13 Decreto no 19.851, de 11 de abril de 1931, também conhecido como Estatuto das Universidades Brasileiras. 
típicos das instituições de cunho "napoleônico", como tenderiam a ser por muito tempo as instituições que iriam constituir-se sob a égide do poder central.

O autor ainda pondera que a fundação da Universidade de São Paulo (1934), em meio à "centralização político-administrativa e ideológica", presente no governo de então, suscitaria a adoção de alguns elementos do modelo alemão nas universidades brasileiras. Sua expansão articula-se ao quadro do pós-Segunda Guerra Mundial, da crescente urbanização do país e da necessidade de profissionais liberais (médicos, advogados, engenheiros), o que levou à expansão do sistema universitário como forma de suprir essa demanda. Vê-se também o surgimento de algumas entidades ligadas ao ensino superior: Sociedade Brasileira para o Progresso da Ciência, SBPC, fundada em 1948; Conselho Nacional de Desenvolvimento Científico e Tecnológico, CNPq, fundado em 1951; Coordenação de Aperfeiçoamento de Pessoal de Nível Superior, CAPES, fundada em 1951. Ferreira (2009, p. 165) defende que essas entidades são "expressões importantes do processo de modernização da educação superior no país", processo que também foi marcado pela criação do Instituto Tecnológico de Aeronáutica (ITA), baseado no modelo universitário estado-unidense. Para Cunha (2007a, p. 130), o ITA se apresentou como uma ilha de modernização do ensino superior, ressaltando que para alguns essa modernização era necessária para se alcançar a maioridade científica e tecnológica, o que reforçaria a "imagem do paradigma do país capitalista hegemônico".

Para Ferreira (2009, p. 166), essa modernização baseada em padrões estadounidenses tinha diferentes propostas, desde a defesa da organização do ensino superior como essencial para a segurança nacional a urgente modernização que pudesse romper "dependência econômica mediante produção de técnicas e formação de profissionais capacitados".

Ferreira (2009, p. 167) ainda defende que a ditadura militar não abandonou o projeto de modernização e que houve um processo de intensificação da "privatização do ensino superior, apesar do controle político e administrativo sobre esse nível de ensino". Para Cunha (2007b), a falta de um projeto para o ensino superior fez com 
que o governo militar se voltasse para os Estados Unidos em busca de diretrizes para a reforma do ensino, o que deu origem ao acordo entre o Ministério da Educação e a USAID (United States Agency for International Development).

Para Trindade (2008, p. 592), uma elite civil, científica ou universitária defendia uma universidade que formasse pesquisadores de alto nível, para isso convenceram os governos militares a investirem e financiarem a pós-graduação. Trindade complementa:

\begin{abstract}
Esse foi o grande paradoxo do regime militar: intervir nas universidades para afastar os professores e estudantes «subversivos» e depois impor um projeto modernizador, que se alimentou, parcialmente, de propostas que vinham da luta universitária e das experiências do período anterior ao Golpe de 1964.
\end{abstract}

Ferreira (2009) esclarece que na década de 1960 intensifica-se a crise universitária, caracterizada por falta de vagas, baixa qualidade de ensino, que aliada à falta de mão de obra qualificada dá origem à reforma universitária de 1968.

Para Cunha (2007a, p. 86):

A política educacional pós-1964 definiu-se pela fragmentação interna do ensino superior, pela segregação das universidades em câmpus e pela privatização, aproveitando as vias abertas na república populista.

É importante ressaltar a relevância dessa política educacional para o ensino superior, uma vez que o conceito de universidade como centro da universalidade do conhecimento se rompe, em razão de ação político-administrativa ideológica, que será refletida na formação cultural de gerações.

Para Trindade (2008, p. 596), a reforma de 1968 teve como consequência a burocratização das universidades públicas. Ele continua:

Hoje, o sistema de educação superior está fragmentado, banalizou-se o conceito de universidade e houve um crescimento descontrolado das instituições privadas. Esse contexto perverso de alta privatização sem planejamento e um sistema público com universidades de pequeno porte é uma das questões centrais que terá de enfrentar uma nova reforma universitária. 
Ferreira afirma que, com a reforma de 1968, a expansão de vagas se deu por meio de estabelecimentos isolados e privados. Além disso, pregava-se um modelo de racionalização e eficiência, como exposto por Sguissardi (2011, p. 283), "chegou à formulação oficial de que a universidade deveria necessariamente associar a pesquisa e o ensino, formulação genérica que poderia ser denominada de neohumboldtiana".

Meneghel (2001, p. 173) reforça, ainda, desdobramentos da reforma de 1968 , destacando a burocracia e o tecnicismo, a indissociabilidade entre ensino e pesquisa, expansão de vagas, implantação da pós-graduação e de atividades de extensão. A autora conclui que a reforma, na prática:

[...] não modernizou o sistema de ensino superior, conforme o desejado, pois pouquíssimas instituições conseguiram estruturar-se de modo a assimilar o modelo proposto. A maioria dos cursos e instituições (existentes ou criados) sequer tentou implementá-lo, tendo se ocupado de "imitar" sua base estrutural e organizacional, ajustando-se às normas e à estrutura jurídica impostas pelo Estado, que com encontrar sua vocação de ensino e pesquisa a partir dos potenciais e demandas do meio em que estavam inseridos.

Já na década de 1980, além de enfrentar cortes de recursos, a universidade continuava a ser criticada por "não trabalhar para o desenvolvimento regional e nacional bem como de não promover a autonomia tecnológica do país" (FERREIRA, 2009, p. 170).

Objeto permanente de debate na esfera nacional, no contexto da promulgação da Constituição Federal de 1988, o modelo universitário brasileiro ganha relevância, agora em direção mais abrangente e universalista:

Como os modelos universitários tendem a ter vínculos estreitos com modelos de desenvolvimento e de concepção da vida democrática e republicana, prevaleceram os princípios de uma universidade, como dever do Estado, que privilegiasse a produção do conhecimento de forma integrada ao ensino, à formação de profissionais competentes e críticos da realidade, respeitada a autonomia e a liberdade do pensamento, concorde com o espírito dessa Constituição, chamada de cidadã. (SGUISSARDI, 2011, p. 284)

Assim, reafirmada a indissociabilidade entre ensino e pesquisa para as universidades, acrescentou-se, ainda, um novo fator, o da extensão. Tanto para 
Ferreira como para Sguissardi, poucas universidades têm conseguido de fato promover o tripé ensino-pesquisa-extensão.

Parece oportuno esclarecer que por ser uma instituição social, a universidade reflete os fatores em voga na sociedade da qual faz parte, seus projetos, políticas e as diferentes classes sociais envolvidas. Pelo exposto até aqui, percebe-se que não houve um consenso acerca de um único modelo de universidade a ser seguido, variando entre padrões dos modelos europeus e estado-unidense.

Os modelos de universidade apresentados refletem as conjunturas em que estão inseridas e são frutos dos debates sobre o papel da universidade. A universidade deve ser de cunho profissionalizante (modelo francês), deve ter foco na pesquisa pura (modelo alemão), centrar-se no desenvolvimento do caráter dos sujeitos (modelo inglês), ou atender às necessidades da sociedade em seu entorno com uma formação utilitária (modelo americano)? Essas discussões perduram até os dias atuais e englobam outros aspectos, como o ensino superior de massa, as exigências do mercado, passando por questionamentos se as universidades devem, ou não, estar a serviço do Estado. Nas palavras de Rossato (s/d, p. 127):

Qual universidade queremos? O modelo iluminista ainda tem lugar? O
modelo pragmatista deve continuar? Em uma sociedade em profunda
transformação pergunta-se: qual o lugar do tradicional e daquelas
preocupações do passado sobre o sentido do humano? Em tempos de
tecnologia, do saber fazer, da pesquisa inovadora, como se coloca a
questão da formação humana? Cabe ainda a questão: que homem
queremos formar? Isso ainda se justifica? Qual o lugar do humano nos dias
de hoje? Em tempos de globalização ainda cabe falar de humanismo na
universidade? Qual humanismo?

Para o autor, as consequências do avanço do neoliberalismo são a mercantilização das relações sociais, incluindo a mercantilização da educação, ou seja, tudo é produto e tudo pode ser consumido. 


\subsubsection{Processo de Bolonha}

O século XX apresentou mudanças significativas nas relações sociais e interculturais (Brandalise; Heinzle, 2020). Para Siebiger (2010), nesse período as universidades também passaram por mudanças para formar profissionais em consonância às exigências do mercado.

Bianchetti; Thiengo (2018) ressaltam que a globalização e a transnacionalização apagaram fronteiras e deslocaram o eurocentrismo para outros partes do mundo. Para os autores,

É nesse mercado-mundo, que a Europa percebe-se perdendo a concorrência, particularmente para os EUA e vê na educação, em especial na reorganização da universidade, uma oportunidade do resgate ou de 'retornar ao jogo' como protagonista. Neste contexto, a questão da organização da UE como um antídoto para a perda da hegemonia e da competitividade em relação, particularmente aos EUA, passa a ser uma espécie de obsessão dos dirigentes europeus. E decisões, medidas passam a ser tomadas a fim de concretizar esta 'viragem' por parte da Europa. ( $p$. 416)

É nesse contexto que se instaura o Processo de Bolonha, a partir da assinatura da Declaração de Bolonha, em 1999, por ministros de Educação de alguns países europeus.

A Declaração de Bolonha tem como propósito "aumentar a competitividade no Sistema Europeu do Ensino Superior", introduzindo um sistema curricular de ciclos. Para Siebiger (2010) o documento estabelecia o Espaço Europeu de Ensino Superior (EES), com o objetivo de incentivar a mobilidade de estudantes, "proceder à uma maior coerência e a equivalência no que tange às estruturas dos cursos superiores e ao reconhecimento de estudos e títulos" (p. 121).

Para Borges (2013), a Declaração de Bolonha ressalta o papel da universidade no desenvolvimento do espaço europeu. Ainda para a autora, a discussão sobre a autonomia universitária muda de eixo e se coloca em termos de gestão administrativa e financeira:

Assim, as universidades são pressionadas a buscarem novas receitas através, principalmente, de parcerias com a indústria e com as empresas, 
sendo a investigação aplicada indicada como a alternativa de conseguir esses novos recursos. (BORGES, 2013, p. 72)

Mello; Dias (2011) apontam como focos de crítica ao Processo de Bolonha pontos que vão da questão da mercantilização e privatização da universidade pública até à perda da autonomia, passando pela adoção de padrões uniformizados do funcionamento acadêmico.

Borges (2013) ressalta que é possível perceber um afastamento do modelo de universidade proposto por Humboldt, para a autora

\begin{abstract}
a liberdade, a autonomia e a investigação universitárias passam cada vez mais a se vincularem aos imperativos das necessidades da economia. Os aspectos acadêmicos, sobretudo aqueles referentes à autonomia didática e científica, à liberdade de ensino e de pesquisa e ao desenvolvimento da pesquisa básica, aspectos estes que distinguem uma instituição universitária, perdem relevância e passam a ser marginalizados no processo de desenvolvimento social e econômico em curso. (BORGES, 2013, p. 75)
\end{abstract}

Para Lima, Azevedo e Catani (2008) o Processo de Bolonha estabelece padrões que devem ser aplicados às instituições de ensino superior, bem como pelas agências de avaliação. Para os autores, essa avaliação centra-se na "comparação entre produtos" (p. 18), e a produção de rankings teria um papel de regulação das universidades, "atuando de forma altamente centralizada em face dos distintos resultados de performance atingidos por cada instituição e 'revelados' publicamente na sequência da avaliação externa" (p. 20).

\title{
2.1.8 Influências do Processo de Bolonha no Brasil
}

Para Lima; Azevedo; Catani (2008), o Brasil é influenciado pela política externa quando se trata de reformas educacionais, adotando modelos estrangeiros. Os autores citam como exemplo a reforma universitária de 1968, com influência estadounidense, e ressaltam que no século $X X I$, qualquer reforma pretendida no âmbito das universidades menciona o Processo de Bolonha.

Siebiger (2010) aponta que o Processo de Bolonha, ao pretender aumentar a internacionalização das instituições de ensino europeias, estende relações com as 
universidades latino-americanas. Assim, algumas iniciativas vão tomando lugar, entre elas: Tratado de Amizade Brasil-Portugal, o projeto de criação da Universidade Federal da Integração Luso-Afro-Brasileira, Universidade Federal da Integração Latino-Americana. Ainda nos moldes do Processo de Bolonha, o Setor Educacional do Mercosul "defende necessidade de se estabelecer um espaço acadêmico regional com a finalidade de propiciar a formação de recursos humanos bem como facilitar o reconhecimento da produção local, creditando sua relevância de modo que possa ter representatividade regional" (SIEBIGER, 2010, p. 124).

Siebiger (2010) também indica que ao seguir o modelo de Bolonha, a realidade das universidades brasileiras seguiria um caminho de privatização das políticas públicas, fazendo com que as universidades se submetessem "às mudanças socioeconômicas advindas dos atuais movimentos de transformação do Estado" (p. 132).

Nesse quadro, discutir a biblioteca universitária no bojo de tais modelos e contexto será um primeiro movimento para compreender parâmetros e suas distinções, tendo em vista seu papel na perspectiva da formação cultural dos estudantes.

\subsection{Biblioteca universitária: bases conceituais}

Embora as bibliotecas sejam instituições mais antigas que as universidades, foi com a criação e desenvolvimento destas últimas que se viram surgir as bibliotecas universitárias. Assim como as universidades têm um longo histórico de evolução, as bibliotecas universitárias também se desenvolvem em função das instituições às quais estão ligadas. Pode-se dizer que as primeiras BUs eram pequenas (para os padrões atuais), com coleções de livros, geralmente doados por algum benfeitor, tome-se como exemplos a doação de 2.500 livros por Thomas Bodley (BODLEIAN LIBRARIES, 2020) para a Universidade de Oxford, em 1598, ou o legado de 400 livros deixados por John Harvard, após a sua morte, em 1638 (HARVARD UNIVERSITY, 2020). 
A compreensão da dinâmica de desenvolvimento do conceito de BU implica a abordagem de alguns fenômenos ligados à história deste dispositivo cultural. Em 1876, o Bureau of Education dos Estados Unidos publica o Public Libraries in the United States of America: their history, condition and management, um relatório contendo dados sobre o estado das bibliotecas públicas de então, aspecto a ser ressaltado, considerando-se que a inclusão das bibliotecas universitárias como bibliotecas públicas provém do caráter público conferido pelo suporte que o Estado dava a essas instituições. Em razão disso, o relatório apresenta capítulos sobre bibliotecas universitárias, científicas, médicas e de direito, incluindo informações sobre as bibliotecas da Universidade da Califórnia, Yale, Harvard, Michigan, Cornell, entre várias outras.

Em um dos capítulos referentes a bibliotecas acadêmicas, as questões tratadas giravam em torno de seleção de livros, sobre o caráter de acessibilidade, ou não, das coleções, além de questionamentos acerca de bibliotecas próprias para escolas ou departamentos. Segundo Budd (1998, p. 36-37), o capítulo incorpora as influências do cientificismo do século XIX, ou seja, "a crença de que o melhor modelo da verdade e a melhor estratégia para a verificação são fornecidos pelas ciências naturais".

Os autores do referido relatório, além de serem bibliotecários de universidades estado-unidenses, estavam envolvidos com a criação da ALA (American Library Association), entre eles, F. B. Perkins, W. I. Fletcher, C. A. Cutter, Melvil Dewey. Organismo em funcionamento ainda na atualidade, a ALA nasce, em 1876, com o objetivo de "promover os interesses bibliotecários, de aumentar a reciprocidade e a boa vontade entre os bibliotecários e todos os interessados em economia bibliográfica e estudos bibliográficos" (AMERICAN LIBRARY ASSOCIATION, 1894, p. 2). A trajetória da instituição, articulada por sucessivos encontros anuais entre seus membros participantes, viabilizou a redefinição de seus objetivos e, em 1894, sua ênfase no caráter profissional inicial cede lugar à abordagem institucional. Conforme disposto, seu propósito passa a ser a promoção do: 
bem-estar das bibliotecas, estimulando o interesse público em fundá-las e melhorá-las, assegurando a legislação nacional estabelecida e necessária, promovendo trabalhos cooperativos que permitam melhorar resultados ou reduzir despesas, trocando pontos de vista e fazendo recomendações e promovendo os interesses comuns de bibliotecários, curadores e outras pessoas envolvidas em trabalhos educacionais relacionados a bibliotecas. (AMERICAN LIBRARY ASSOCIATION, 1894, p. 3) ${ }^{14}$

Os encontros anuais também vão delineando as seções da associação. Assim, em 1889 acontece o primeiro encontro da College Section, em que se discutiu mais amplamente "tópicos peculiares às bibliotecas de instituições de ensino" (AMERICAN LIBRARY ASSOCIATION, 1894, p. 19).

No encontro de 1890, a College Section debateu tópicos, como a relação do bibliotecário com o corpo docente e com os estudantes e as questões sobre circulação do acervo, desde o sistema para registro até a quantidade de volumes e o tempo de empréstimo, tanto para docentes como para estudantes. Os itens estabelecidos para debate ganham abrangência, incluindo desde questões práticas (empréstimos, acesso às prateleiras, horário de funcionamento) até questões mais complexas, como o escopo e a função de bibliotecas departamentais de universidades (AMERICAN LIBRARY ASSOCIATION, 1890).

Com denominação alterada, em 1897, para College and Reference Library Section, o novo nome é forma de reconhecimento da participação dos bibliotecários de referência nos debates da associação. $O$ fortalecimento da seção se evidencia em meados da década de 1920, quando adota estatuto próprio e na década de 1930 quando passa a ser reconhecida como uma associação, reflexo da organização profissional que propunha realizar uma gama de atividades, programas, pesquisas e publicações. (ASSOCIATION OF COLLEGE AND RESEARCH LIBRARIES, 2020)

O Conselho da ALA reconheceu a ACRL como a primeira divisão da ALA em 31 de maio de 1940. Em 1956, a ACRL passa a se denominar Association of College and Research Libraries e, em 1957, publica Standards for College Libraries, um primeiro

14 Its object shall be to promote the welfare of libraries by stimulating public interest in founding and improving them, by securing needed stated and national legislation, by furthering such coopertative work as shall improve results or reduce expenses, by exchanging views and making recommendations and by advancing the common interests of librarians, trustees and others engaged in library or allied educational work. 
conjunto de diretrizes para bibliotecas universitárias ${ }^{15}$, documento constantemente revisado e atualizado.

$\mathrm{Na}$ revisão mais recente de seu Plan for Excellence, a ACRL converge para quatro pontos a serem trabalhados: valorização das bibliotecas acadêmicas; aprendizagem do aluno; ambiente acadêmico e de pesquisa; e novos papéis e perspectivas. Ao trabalhar a valorização das bibliotecas, a instituição tem por objetivo promover o impacto e o valor das bibliotecas acadêmicas e de pesquisa para a comunidade do ensino superior, bem como apoiar as bibliotecas na articulação de seu papel no avanço de questões de equidade, acesso, diversidade e inclusão no ensino superior.

Ao desenvolver o segundo ponto, a aprendizagem do aluno, o documento salienta a promoção de práticas e ambientes pedagógicos equitativos e inclusivos para as bibliotecas, para apoiar o aprendizado dos alunos, com objetivo de capacitar as bibliotecas a criarem programas sustentáveis, inclusivos e responsivos de informação, e de colaborar com parceiros internos e externos para expandir a compreensão do impacto da information literacy na aprendizagem dos alunos.

Em sua dissertação, Nascimento expõe que o conceito de information literacy é apresentado no relatório "The Information Service Environment Relationships and Priorities”, de Paul G. Zurkowski, publicado em 1974, e se dissemina pelo mundo, em consequência da forte presença das tecnologias de informação e comunicação na vida social. Para Nascimento (2018, p. 61), neste relatório, ao detectar a necessidade de programas que desenvolvessem aprendizagens informacionais, Zurkowski propunha uma estratégia para a política, tendo em vista "tornar os cidadãos americanos, em uma década, Information Literates", defendendo tratar-se de condição para uma sociedade e economia digitais.

Para Nascimento, desde a Segunda Guerra Mundial, nos EUA, as bibliotecas, por exemplo, passaram a ser percebidas como importantes suportes de acesso a informações, o que culminaria com a sua valorização e proliferação. Neste contexto,

15 A ACRL trata "academic library" como termo abrangente para se referir às bibliotecas de ensino superior, podendo incluir, por exemplo, bibliotecas de faculdades e de universidades. 
na década de 1960 a Comissão Nacional Consultiva de Bibliotecas sugere a criação da National Commission on Libraries and Information Science (NCLIS), concomitantemente ao surgimento de iniciativas ligadas a problemática informacional, com objetivo de "educação de usuários". O programa Chicano Library Program, da Universidade da Califórnia, por exemplo, formulava diretrizes procedimentais para uso da biblioteca por alunos latinos, com dificuldades em relação ao uso da biblioteca universitária e da informação científica.

Assim a information literacy vai se formando com bases em procedimentos de uso das bibliotecas, metodologias, modos de buscar informações correntes, cujo domínio é fundamental ao desempenho adequado nos circuitos acadêmicos. A integração entre bibliotecas e os outros sistemas de informação passa a ser vista, em decorrência, como essencial diante do desenvolvimento informacional e tecnológico. Conforme destaca Nascimento (2018, p. 70), na década de 1980, com o trabalho de Kuhlthau, a information literacy passa a ser vista como um "conjunto de conhecimentos, habilidades e atitudes, por meio da aprendizagem baseada em recursos".

Algumas críticas feitas à information literacy apontavam sua limitação ao desenvolvimento de aprendizagens operacionais de utilização dos recursos tecnológicos, tornando apta a força de trabalho para os processos produtivos, bem como explicitaria uma visão superficial, "não uma construção de saberes, mas o domínio de caminhos prescritos que possibilitam acesso informacional, ficando seu uso efetivo em segundo plano" (NASCIMENTO, 2018, p. 80). Para Nascimento, no final do século $\mathrm{XX}$, a concepção de information literacy se expande para além dos EUA e passa a ser um modelo a ser seguido em vários países. Isso fica claro ao se perceber que os próprios profissionais bibliotecários aceitaram a ideia da information literacy, que é adotada como resposta para os problemas educacionais dos EUA por parte das bibliotecas. A presença da ALA no Presidential Committee on Information Literacy, formado em 1987, resultará no Presidential Committee on Information Literacy: Final Report, publicado em 1989, e cujas ideias, de acordo com o apresentado nesse relatório, têm um amplo alcance e uso, inclusive pela própria IFLA, como vemos na figura a seguir. 
Figura 1 Página da IFLA utilizando definição proposta pela ALA

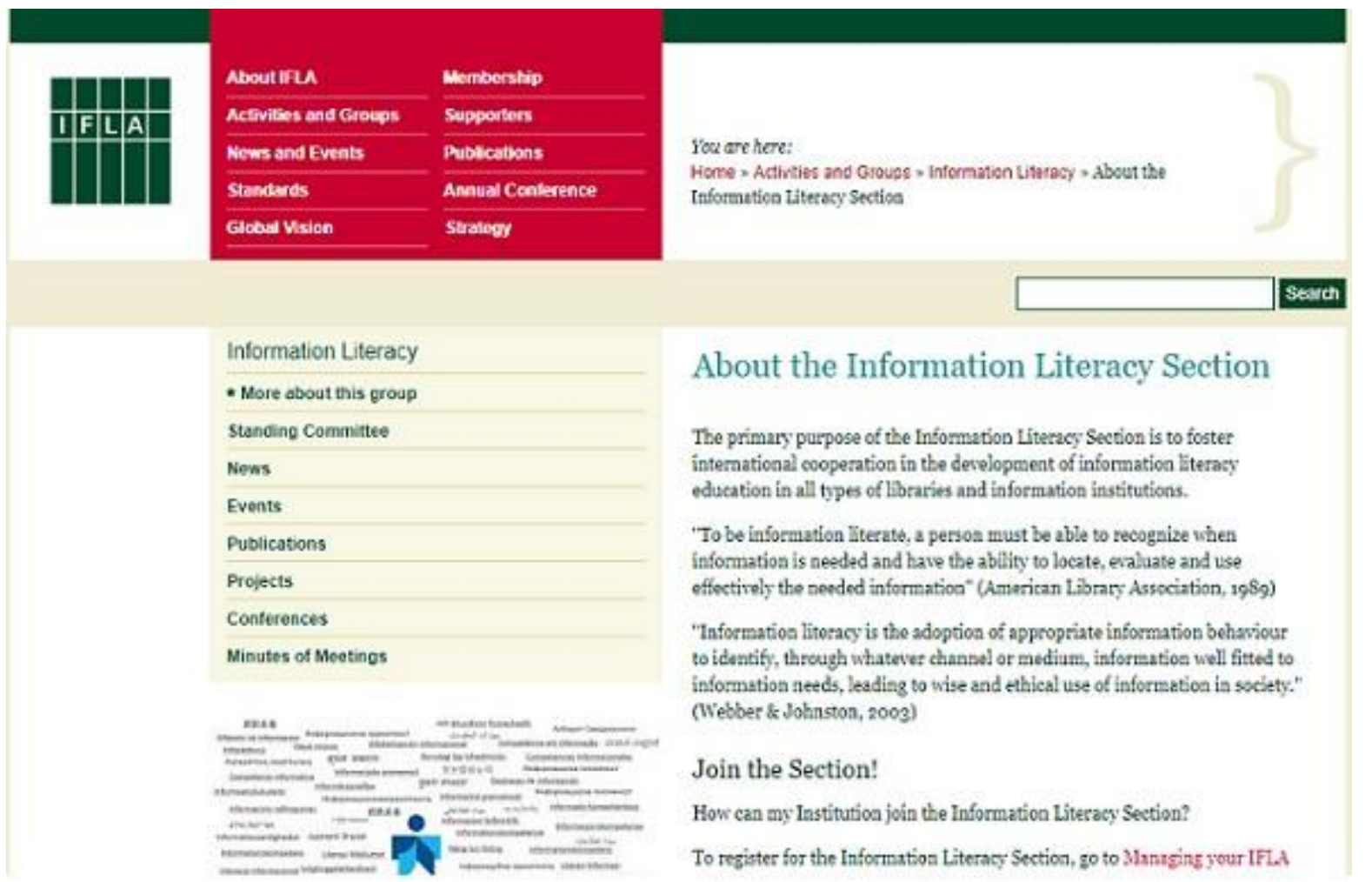

Fonte: IFLA, 2020.

O debate mostra-se fundamental aqui, uma vez que a information literacy tem impacto importante nas bibliotecas universitárias: a própria $A C R L$ revisa os modelos propostos por sua seção de instrução e acaba desenvolvendo diretrizes de IL, propondo, posteriormente, diretrizes específicas para áreas diversas (por exemplo, para os estudantes de antropologia, sociologia, jornalismo).

Parece claro que ao longo do tempo as questões envolvendo as BUs nos Estados Unidos têm mudado em virtude da dinâmica da sociedade. Em 1939, Leupp traz à tona questionamentos acerca das mudanças pelas quais as bibliotecas universitárias passavam e as tentativas de adaptação, as quais estavam relacionadas com o aumento no número de cursos e pesquisas de pós-graduação, defendendo serem "necessárias mudanças fundamentais, incorporando concepções de serviço de biblioteca para universidades que diferem radicalmente daquelas defendidas até então" (LEUPP, 1939, p. 57). Neste artigo, o questionamento é relativo ao 
desenvolvimento de coleções e infraestrutura para mantê-las, tendo em vista atender os diferentes cursos.

Contemporaneamente, em 2019, a American Library Association caracteriza a BU como biblioteca que, em conjunto com outros membros de sua comunidade, participa, apoia e realiza a missão educacional da instituição da qual faz parte. Para isso, deve "ensinar as principais competências de information literacy", desenvolvendo "programas e serviços instrucionais".

Cunha e Cavalcanti (2008, p. 53) definem biblioteca universitária como organismo que é mantido "por uma instituição de ensino superior e que atende às necessidades de informação dos corpos docente, discente e administrativo, tanto para apoiar as atividades de ensino, quanto de pesquisa e extensão". Os mesmos autores também trazem uma definição de biblioteca universitária estado-unidense: essa biblioteca seria "criada, mantida e administrada por uma faculdade (college) para suprir as necessidades de informação dos professores e estudantes, bem como manter programas educacionais de pesquisa e extensão", sem alusão, note-se, ao atendimento das necessidades informacionais dos funcionários administrativos da universidade.

Reitz (2013), por sua vez, define a BU como parte integrante de qualquer tipo de instituição de ensino superior, devendo atender às necessidades de informação e pesquisa de seus alunos, professores e funcionários.

Essas definições trazem em si diferentes concepções de biblioteca universitária, em termos de objetivos, missão, público a ser atendido, todos esses aspectos, porém, intrinsecamente relacionados com a própria concepção/modelo de universidade ao qual estará ligada.

Conforme apresentado anteriormente, os modelos universitários constituem categoria a ser observada na análise de concepções e/ou paradigmas de biblioteca universitária, dado estarem implicadas nos respectivos contextos em que se inserem. Nesses termos, existiriam tantos diferentes conceitos de biblioteca universitária quantos forem os conceitos de universidade. Para Budd (1998, p. 4): 
[...] embora haja alguma consistência de missão (todos reconhecem um imperativo educacional), há um considerável grau de diversidade no ensino superior. A universidade de pesquisa e a faculdade comunitária são, de certa forma, mundos à parte ${ }^{16}$.

Assim, a biblioteca universitária reflete a instituição na qual se inclui, com estruturas administrativas próprias, além de ser parte das políticas e culturas do universo acadêmico. Em razão dos diferentes modelos universitários teríamos, conforme antes considerado, variados conceitos de biblioteca universitária, enfatizando múltiplos eixos de ação, que podem incluir desde o desenvolvimento de competências e habilidades informacionais, passando pela oferta informacional, até dinâmicas ligadas à memória científica, entre outros.

Nunes e Carvalho (2016, p. 174) veem as bibliotecas universitárias como lugar de destaque na sociedade atual, em razão de estarem inseridas no contexto da universidade, "agente catalisador e difusor do conhecimento científico". As BUs são espaços de difusão do conhecimento, em que se destaque "sua importância, sua evolução e suas contribuições para a formação crítica e ética de indivíduos capazes de exercer com êxito seu protagonismo social" (NUNES; CARVALHO, 2016, p. 175). Elas ainda afirmam que as BUs têm como objetivo:

[...] atender as necessidades de todos os membros da comunidade acadêmica da qual fazem parte, mas num processo dinâmico, onde cada uma de suas atividades não é desenvolvida de maneira estática e mecânica, mas com o intuito de agir interativamente para ampliar o acesso à informação e contribuir para a missão da universidade (NUNES; CARVALHO, 2016, p. 179)

Para Santos (2012, p. 22), a BU "atua como dispositivo informacional voltado a favorecer o crescimento social e cognitivo dos sujeitos". Além disso, Santos, Gomes e Duarte $(2014$, p. 3) entendem a biblioteca como facilitadora do "processo dialógico entre sujeitos, seja em um mesmo momento histórico, com os debates e trocas de informações que podem ocorrer em seus espaços físicos e/ou virtuais, ou ainda em tempos históricos distintos, quando os usuários da informação têm acesso aos conhecimentos registrados".

16 Although there is some consistency of mission (all recognize an educational imperative), there is a considerable degree of diversity in higher education. The research university and the community college are, in some ways, worlds apart. 
Reforçando a ideia de que a BU é reflexo da instituição da qual faz parte, cabe lembrar que o SINAES (Sistema Nacional de Avaliação do Ensino Superior), ao avaliar as instituições de ensino superior, leva em consideração, entre outros aspectos, "a responsabilidade social da instituição". Assim, é impreterível se pensar na responsabilidade da $\mathrm{BU}$ por conseguinte. Para além de dar suporte às atividades de ensino e pesquisa e atender a discentes e docentes, a BU também tem responsabilidade social com a comunidade na qual está inserida. Apresentar-se não apenas como disseminadora de informação, mas como espaço dialógico, que se oferece como possibilidade relacional entre a memória cultural/patrimônio científicocultural, sujeitos e a construção de saberes.

Desse modo, reconhecer e compreender nuances no contexto da biblioteca universitária abre um leque de possibilidades para torná-la um ambiente dinâmico e vivo, tal como é demandado nos quadros contemporâneos, considerando-se a diversidade de contextos socioculturais e educacionais existentes e seu compromisso com a construção de sujeitos do conhecimento.

\subsection{Dispositivo cultural: uma chave de análise}

Definir biblioteca como dispositivo cultural permite agregar ao conceito valor de significação. Como tal, natureza e caráter de seus elementos e respectivas articulações, não somente se referem à configuração de ambientes de informação e cultura, com funções e finalidades próprias, como também são categorias constitutivas de representações, imagens que afetam relações entre sujeitos, biblioteca, conhecimento e cultura. Os dispositivos produzem significados, são narrativas, discursos que atuam em dimensão que extrapola sua materialidade.

Para Pieruccini (2004, p. 43):

O dispositivo é [...] signo, mecanismo de intervenção sobre o real, que atua por meio de formas de organização estruturada, utilizando-se de recursos materiais tecnológicos, simbólicos e relacionais, que atingem os comportamentos e condutas afetivas, cognitivas e comunicativas dos indivíduos. Dessa forma, os efeitos dos dispositivos, ou seja, dos meios 
dirigidos, ultrapassam os limites técnicos visíveis para tornarem-se, em nossa sociedade, instrumento da relação conosco, com os outros e com o mundo. Nesta perspectiva, os comportamentos culturais contemporâneos (como visitar museus, navegar na internet, ir à biblioteca) são formas de atuação com e nos dispositivos, orientadas por regras e leis próprias dos meios em que se encontrem.

Os dispositivos informacionais, ao interferirem sobre a matéria básica com que lidam - as informações, suas linguagens, organização e interações -, criam sistemas que funcionam como códigos aplicados à sua ordenação e comunicação, ou seja, linguagens específicas, constituídas na tentativa de ordenação do caos.

Nesses termos, o conceito de dispositivo cultural deverá oferecer subsídios à análise da relação biblioteca universitária-formação cultural, questão em foco na pesquisa, a partir de sua articulação entre duas noções chaves: mediação cultural e apropriação cultural.

Assim, os dispositivos, portanto, não são meras ferramentas neutras, mas ambientes de significação nos quais, como diz Perrotti (2016, p. 18), "a informação toma existência", objetivada em modelos institucionais, marcados por sua intencionalidade. Com base nessa perspectiva, o autor propôs categorização que articula modelos de bibliotecas e paradigmas culturais - conservação, difusão e apropriação cultural - nomeando-os respectivamente, de bibliotecas templum, emporium e forum.

O modelo de Biblioteca Templum (PERROTTI, 2016) tem como pressuposto o paradigma da conservação cultural, caracterizado pela guarda e preservação do patrimônio da cultura letrada (cultural). Os saberes nela encerrados passam a ter sacralidade, no sentido de que inspiram grande respeito ou veneração. Assim, o saber seria algo inatingível, a não ser para um grupo diminuto. Além disso, ao ter por base a preservação, volta-se a uma série de práticas, como controle do acervo e o bloqueio do público, categorizando e diferenciando quem pode ou não ter acesso a esses bens:

As dimensões formativas dessas bibliotecas, quando existentes, dizem respeito, portanto, a públicos já formados, especializados, cultivados em relação ao patrimônio guardado. Supõe-se e espera-se que eles sejam detentores de saberes que não colocariam em risco os "tesouros do templo". (PERROTTI, 2016, p. 24) 
No modelo de Biblioteca Emporium, o foco deixa de ser a conservação e passa a ser a difusão cultural, e a biblioteca configura-se como distribuidora de informação e cultura, com base na crença de que o acesso aos objetos culturais possa equivaler à apropriação de bens simbólicos:

\begin{abstract}
O discurso da difusão cultural que, até os dias atuais, vem orientando e justificando a constituição da maior parte dos nossos dispositivos de informação que não desejam ser apenas locais de preservação e guarda de memória, parte da premissa de que a disponibilização de bens culturais gera automaticamente apropriação. Nesse sentido, tal discurso reduz a problemática da apropriação cultural a simples questão de acesso, deixando de considerar as dimensões histórico-culturais que aí intervêm e suas consequências. Desaparecem, em decorrência, as fraturas culturais que marcam a vida social, em especial em sociedades profundamente desiguais como a brasileira e as dificuldades de toda espécie geradas por tal fato. (PERROTTI, 2016, p. 19-20)
\end{abstract}

O fundamento do acesso geral ignora diferenças de público, apaga especificidades individuais, ou mesmo de diferentes grupos. Embora este paradigma não tenha mais o ar de sacralidade, ainda concentra importância no acervo, uma vez que suas ações estão focadas no acesso livre desses bens, não reconhecendo a "cultura dos diferentes públicos" (PERROTTI, 2016, p. 25). E ainda:

De qualquer forma, do ponto de vista formativo, os dispositivos de difusão cultural pretendem ser instâncias que, ao possibilitarem acesso aberto aos bens culturais, favorecem a educação de seus públicos, colocando-os em relação com o conhecimento, aquilo que consideram ser a "boa" cultura, valor atribuído em geral aos repertórios por eles selecionados e disponibilizados. (PERROTTI, 2016, p. 25)

Ao entender que é preciso lidar com as "fraturas culturais" e que a simples disponibilização de bens culturais não gera apropriação, passa-se a um outro modelo, o da Biblioteca Forum, dispositivo dialógico, lugar de fala e escuta, de mediação de repertórios culturais.

Neste modelo, a centralidade é a dialogia cultural, base para a construção (versus reprodução) de conhecimentos, os quais só são possíveis pela dinâmica das trocas e das negociações simbólicas:

O dispositivo constitui-se em processo contínuo, a partir das diferentes vozes que nele ecoam. Nesse sentido, por suas configurações e processos - e não somente pelos conteúdos que disponibilizam - eles formam, apontando em direção à cidadania cultural, à participação em processos de 
criação e não de mera assimilação ou consumo irrefletido de signos. (PERROTTI, 2016, p. 21)

Na Biblioteca Forum, práticas e ações serão fomentadas no pressuposto da apropriação cultural, questão que implica dar centralidade aos princípios da diversidade e protagonismo cultural, articulando-os a contextos e processos educativos de construção de saberes:

\footnotetext{
Nesses termos, o dispositivo forum desempenha um papel educacional fundamental, assumido e desenvolvido como forma de preparar condições para os embates sígnicos e colaborações envolvendo atos de protagonismo e de criação culturais. (PERROTTI, 2016, p. 24)
}

Desse modo, evidencia-se que o paradigma da apropriação cultural se reflete em práticas sociais concretas, cujos processos são dinâmicos, orgânicos e complexos, frutos de diálogos constantes, mesmo que por vezes tensos e difíceis, uma vez que, nesta perspectiva, não se trata mais de um modelo de biblioteca voltado a usuários, enquanto categoria passiva, mas sujeitos-protagonistas culturais, ou seja, "o forum atua, portanto, na formação de identidades cidadãs, afinadas com processos de participação afirmativa nas dinâmicas culturais" (PERROTTI, 2016, p. 26), o que parece estar em consonância com o conceito de formação cultural que veremos a seguir.

\subsection{Formação cultural: um paradigma para a biblioteca universitária}

O conceito de formação cultural, por vezes traduzido como Bildung, constitui referência central ao debate do objeto em causa nesta pesquisa. Buscar compreender e situar a biblioteca universitária em paradigma que ultrapasse perspectivas de difusão documentária e informacional, demanda considerar seu caráter educativo, inscrito na ordem institucional que a orienta. Por esta razão, considerar a ideia de formação cultural como categoria central permite observar criticamente os limites da biblioteca vinculada ao ensino (ou pior) à escolarização.

A definição de "formação cultural", segundo Severino (2006, p. 631), implica separar os termos, esclarecendo que "formação" é tomado como "constituição do sujeito que 
não tem molde onde se encaixar, para se enquadrar, medidas para se medir", diferenciando-o da definição de "moldar". Já o termo "cultural" implica não só o conceito de erudição, ilustração, mas articula-se "na experiência vivenciada da autorreflexão crítica, na autonomia do sujeito humano como praticante do exercício público da racionalidade".

Para Biesta (2002a, 2002b), por sua vez, Bildung representa um ideal de formação humana que surgiu na sociedade grega e que perpassou a cultura romana, bem como fez parte dos ideais do Humanismo e do lluminismo, tornando-se uma das noções centrais da tradição educacional ocidental moderna que influenciou o sentido atribuído à definição de pessoa educada. $\mathrm{O}$ autor refere-se a Bildung como processo de desenvolvimento da mente humana, mais precisamente ao cultivo da humanidade de cada indivíduo.

O termo Bildung, todavia, passou a ser adotado somente na segunda metade do século XVII, conforme indicam Suarez (2005) e Möllmann (2011). Por seu caráter dinâmico, o termo se vincula a movimentos, como o lluminismo, idealismo filosófico e pedagógico, neo-humanismo e romantismo (MÖLLMANN, 2011) e passa a expressar "o elemento definidor, o processo e o resultado da cultura" (SUAREZ, 2005, p. 193). Nicolau (2013) também entende o termo como o processo de formação humana. Para ele, "pensar a Bildung significa refletir os diversos momentos que o homem experiencia na busca de ser mais" (NICOLAU, 2013, p. 36).

Considerações apresentadas no livro A individualidade numa época de incertezas, o conceito de cultura animi (cultivo da alma) foi retomado no final do século XVIII, na França e, junto à Bildung germânica, transmitiam que:

[...] os seres humanos não nascem humanos, eles se tornam humanos - no incessante esforço de autoformação, autoafirmação e autoaperfeiçoamento -, todos eles guiados, dirigidos, auxiliados e instigados pela comunidade humana em que ingressaram ao nascer. (BAUMAN; RAUD, 2018, p. 11)

Nicolau relaciona Bildung e a aspiração de uma vida melhor e, nesse sentido, o conceito apresenta dois aspectos: o do indivíduo que forma e desenvolve a si e a 
seu meio cultural em um processo criativo por sua própria ação; e o do processo de alcançar a humanidade por meio de "tornar-se o que se é" (NICOLAU, 2013, p. 36).

De acordo com tais perspectivas, podemos perceber a concordância das acepções de Bildung e formação cultural, conforme Nicolau e Severino. A formação cultural:

[...] deve ser concebida como a própria humanização do homem, a ser pensado como um ente que não nasce pronto, que tem necessidade de cuidar de si mesmo como que buscando um estágio de maior humanidade, uma condição de maior perfeição em seu modo de ser humano. (SEVERINO, 2012, p. 27).

A ideia de formação de si e do mundo também está presente no texto de Möllmann (2011), em que Bildung é apresentado como conjunto de ideias que culminaria em um "conceito universal de humanidade", sendo o homem visto aqui como um "sujeito capaz de autodeterminação racional” (2011, p. 17), o que o torna um ser autônomo, apto a "se abstrair do seu particularismo em direção ao universal, à humanidade" (2011, p. 8).

A ideia de autonomia racional foi incorporada ao conceito de Bildung durante o lluminismo (Biesta, 2002b). Möllmann (2011, p. 20) afirma que, ainda no século XVIII, são associados à ideia de Bildung os conceitos de liberdade, emancipação, razão, autodeterminação. Esses conceitos representariam a ideia de que o indivíduo, além de sua "natureza orgânica", "tem a liberdade de escolha; liberdade que quase se impõe como uma tarefa a ele no processo de se tornar humano".

\subsubsection{Dimensões de Bildung}

Em sua análise do conceito de Bildung na obra de Hegel, Nicolau constata que a formação "deve conduzir o indivíduo ao reconhecimento de si enquanto cidadão portador de uma vontade consciente e livre" (NICOLAU, 2013, p. 185). Assim, Bildung se configura um processo de "socialização e politização", o qual deveria ser institucionalizado, ou seja, estabelecer-se nas várias esferas da vida social. Nicolau defende, ainda, que a escola é uma das principais instituições fornecedoras dos 
"fundamentos necessários à vivência da política, da ética e da estética - o tripé que sustenta as ações humanas" (2013, p. 182), o que caracterizaria a institucionalização da Formação Cultural. Cabe observar, em contraponto, o conflito aparentemente explicitado entre a dimensão mercadológica de lógicas e esferas educativas e as perspectivas da formação cultural não submetidas, inclusive, a modos de educação fragmentária.

Ao institucionalizar-se a Formação Cultural com base na política, na ética e na estética, tem-se em vista o cidadão "apto para efetivar a Liberdade" (NICOLAU, 2013, p. 182), isto é, indivíduos livres e conscientes, "capazes de se autolimitar". Ao tornar esses sujeitos aptos para a vida em todos os seus aspectos: ético, estético, político e social (p. 185), é possível entender Bildung ou Formação Cultural como o processo que capacita os sujeitos a relacionarem-se "com o mundo objetivo e com seus pares, formando o cidadão" (NICOLAU, 2013, p. 183).

Nicolau (2013, p. 187) ainda ressalta:

Deduz-se da proposta hegeliana que uma proposta formativa autêntica e verdadeira deve a) estar centrada no ser humano e seus direitos, deve b) promover a justiça social, deve c) preparar para a participação política, deve d) capacitar para a participação econômica (trabalho), e deve findar na e) obtenção da autonomia/liberdade, concedendo a cidadania aos indivíduos.

Alguns autores têm discutido sobre as dimensões da Bildung (BOHLIN 2013; NICOLAU, 2013; MÖLLMANN, 2011), baseadas na divisão da razão de Kant (BOHLIN, 2013). Em consonância com esse princípio, seria possível a existência de uma dimensão ética, uma cognitiva e outra estética, bem como uma dimensão política do conceito.

Nas diferentes perspectivas apresentadas, Bildung representa um ideal de educação dos indivíduos, isto é, um princípio de formação de sujeitos éticos, cidadãos e livres. Nesse processo, a formação da consciência passa pela compreensão de si e do mundo, por meio de saberes éticos, sociais e políticos.

Para explicar o conceito de "compreensão de si" e tomando-se por base o sentido de processo de Bildung, Suarez faz analogia entre Bildung e viagem: 
Para tornar-se o que é o viajante experimenta aquilo que ele não é, pelo menos, aparentemente. Pois está subentendido que, no final desse processo, ele reencontra a si mesmo. (SUAREZ, 2005, p. 194)

Assim, a compreensão de si passa pela experiência da alteridade e, nesse sentido, segundo Biesta (2002b), Bildung deve promover essa experiência do encontro com o diferente, experiência que desafia as certezas de cada um:

Antes de tudo, é preciso enfatizar que a razão para isso não deve ser tentar tornar familiar a nós aquilo que é estranho e diferente. Estou pensando mais em algo que Hannah Arendt chamou de "visita". (...) Em vez de tornar o estranho familiar, portanto, poderíamos dizer que visitar é uma abordagem à Bildung que visa tornar o familiar, o que pensávamos que sabíamos e entendíamos, estranho. (BIESTA, 2002a, p. 349) ${ }^{17}$

Sob essa ótica, as considerações de Suarez (2005, p. 194) com base no pensamento de Hegel, indicam que o conceito representa "[...] ruptura com o imediato e passagem do particular ao universal, mais ainda, elevação ao universal, conotando aprimoramento, engrandecimento". Além disso, apresenta a relação de Bildung como trabalho, ou seja, "Bildung é formação prática, formação de si pela formação das coisas" (SUAREZ, 2005, p. 194).

Assim, como processo, na perspectiva de Möllmann, Bildung se apresenta como "um programa de transformação social através da formação dos indivíduos" (2011, p. 25), um ideal de humanidade pela unidade e "por laços universais" (2011, p. 25). A autora ainda explica:

Não se trata de um sujeito preso em seu mundo interior, na sua subjetividade, mas há a proposta de troca com o mundo, num movimento que exige a saída de si ao encontro do mundo e o posterior retorno. Eis a Bildung: ela nos obriga ao distanciamento e estranhamento, ao não imediato, nos obriga a pensar, a lembrar, para depois voltar para casa. (MÖLLMANN, 2011, p. 23)

Esse movimento de distanciamento e estranhamento tem ligação com o que Flickinger (2011, p. 163) chama de cultura de conflito, que se baseia no debate e "em fazer dele o espaço de abertura a horizontes temáticos inesperados". Nesse

17 First of all it must be stressed that the reason for doing so should not be to try to make what is strange and other familiar to us. I am more thinking of something which Hannah Arendt has referred to as "visiting." (...). Rather than making the strange familiar, therefore, we could say that visiting is an approach to Bildung that aims at making the familiar, that what we thought we knew and understood, strange. 
aspecto, o conceito de Bildung contribui ao estudo da biblioteca universitária compreendida como dispositivo educativo dedicado à construção do pensamento autônomo, à emancipação intelectual, à valorização da diferença como categoria da criação de novos significados para o mundo simbólico.

\subsubsection{Críticas ao conceito de Bildung}

Em sua tese, Möllmann (2011, p. 47) apresenta críticas ao conceito de Bildung feitas ainda no século XX. Para ela, o processo de "descentramento" por que passa o indivíduo, fruto das mudanças ocorridas nas ciências sociais e humanas, influenciaria a Bildung, pois o "sujeito que a partir dessas rupturas se desenha é completamente diferente daquele idealizado e pressuposto no século XVIII”.

Em posição semelhante, a crítica de Flickinger (2011, p. 154) está articulada ao ideal lluminista e às mudanças daí advindas que, segundo ele, fizeram com que a razão se tornasse "referencial último do saber e do agir", o que acarretou alterações também nos campos social, cultural e político, bem como na educação. Para o autor, "a razão humana atribuiu a si mesma não apenas a tarefa de decidir sobre as condições do conhecimento objetivo como assumiu também a responsabilidade pela construção dos ambientes social, cultural e político, de modo que o campo da educação não escapou dessas diretrizes iluministas".

No bojo de tais debates, Möllmann (2011, p. 49) chama a atenção para o fato de a educação estar se transformando em bem econômico, reduzindo-se a "mera competência técnica", e o conhecimento ser avaliado de acordo com sua função, ou seja, a partir de sua "aplicabilidade para a vida", indo ao encontro do pensamento de Flickinger, quando aponta que o processo de formação, restrito ao cumprimento de demandas do mercado de trabalho:

[...] não consegue explorar o potencial do educando; muito pelo contrário, impõem-se-lhe exigências que o empurram a tomar caminhos predefinidos sem o questionamento de sua concreta adequação. O sistema de formação jamais toma as alternativas culturais e suas práticas, vividas fora dos 
espaços institucionalmente organizados, como sinais de contestação da "normalidade" social. (FLICKINGER, 2011, p. 163-164)

As discussões sobre a formação profissional continuam em autores como Severino (2012, p. 27), para quem além da qualificação profissional em que conste o "domínio das ferramentas investigativas", bem como uma perspectiva epistemológica, é intrínseco ao ensino superior "o desenvolvimento da formação cultural das novas gerações, que possa situá-las no contexto mais amplo da vida social". Trata-se de abordagem abrangente, com foco em perspectiva cidadã, que se contrapõe a distorções do conceito de Bildung, reduzida "ao saber do 'como' saber", conforme Möllmann (2011, p. 49) chama atenção. Essa visão é compartilhada por Alves (2019, p. 2), para quem "a formação tende a ser integralmente funcionalizada pelo sistema econômico, em nome de valores como eficiência, competitividade e flexibilidade". Para Flickinger (2011, p. 164), a formação não deve se reduzir "à tarefa de profissionalizar o educando para integrá-lo o mais rápido possível ao mercado de trabalho", defendendo que a formação ultrapassa "uma racionalidade meramente instrumental" e que atua além de espaços institucionalmente definidos como legítimos, concluindo que:

Tanto a concepção da formação enquanto busca do saber e dos modos adequados de atuação, quanto aquela da importância de espaços institucionalmente não administrados são reivindicações de relevância inquestionável. (FLICKINGER, 2011, p. 164)

Para Möllmann (2011, p. 13), as contingências estão presentes e o indivíduo vive uma "ambivalência, a da liberdade acareada com uma existência mundana cerceada" e a questão que se apresenta é a da autonomia do sujeito, sua emancipação e sua liberdade. A questão, em perspectiva ética, é sintetizada por Flickinger (2011), quando considera que ao abandonarmos um conceito de Deus todo-poderoso, a razão passa a ser fundamental para a "conquista da autonomia e da liberdade", fazendo com que a educação seja essencial nesse processo. Ele prossegue:

Autonomia e liberdade, os grandes objetivos a serem alcançados segundo a visão iluminista, revelam desse modo um fundo surpreendente. Na verdade, tais objetivos brotam forçadamente a partir de uma exigência de legitimação que cria também, por sua vez, uma ampla responsabilidade, no que diz respeito aos efeitos da própria atuação. É uma experiência, portanto, 
também paradoxal. Autonomia e liberdade remetem a um fundo de necessidade herdada que pode transformar-se em um pesadelo. (FLICKINGER, 2011, p. 155)

Neste ponto, retomando consideração de Alves, vale sublinhar o objetivo de Bildung, ou seja, "possibilitar a afirmação da singularidade individual por meio do cultivo de si e, ao mesmo tempo, conciliá-la com o vínculo comunitário" (ALVES, 2019, p. 12). Em complementação afirma:

Seu potencial crítico, portanto, a despeito dos usos equivocados, permanece no presente. Em educação, continua sendo um dos modelos fundamentais para pensar as finalidades da educação para além do imediatismo exigido por gestores, mercados e governos. (ALVES, 2019, p. 13)

Alves traz a ideia do valor da Bildung como um processo qualitativo, uma vez que não seria possível medi-lo nem quantificá-lo, conforme já indicara Nicolau, ao considerar que Bildung constitui um processo em que o indivíduo age de maneira a formar e desenvolver a si mesmo, retomando a ideia de tornar-se o que se é, aspirando uma vida melhor.

É entendendo Bildung como processo, portanto, que é possível apreender esse movimento de construção da autonomia do indivíduo, permitindo a realização de seu potencial:

[...] este mesmo processo exige da pessoa a disposição de deixar transparecer, sem pudor narcísico, suas próprias falhas e fraquezas. Aceitando, assim, o outro no seu ser diferente e como desafio no que diz respeito a nossa própria autoimagem, alcançamos uma postura de responsabilidade que nos obriga a lançar sobre nós mesmos um olhar reflexivo, desapiedado e crítico. (FLICKINGER, 2011, p. 165-166)

O conceito de Bildung, ideal de formação humana, conforme apresentado, fornece referência consistente no âmbito das bibliotecas universitárias e de seu papel como dispositivo cultural dedicado ao desenvolvimento do pensamento livre e autônomo. Articulado à ideia de cultivar a humanidade (BIESTA, 2002b), Bildung provoca reflexões que dizem respeito à $\mathrm{BU}$ como categoria da mediação cultural, central nos processos de relação entre sujeitos e o patrimônio simbólico, com o qual lida. 
A consideração do paradigma da apropriação cultural abre perspectivas para incluir as bibliotecas, de modo geral, como dispositivos que atuam nos processos de formação cultural. Essa ideia está em conformidade com o conceito de Bildung proposto por Biesta (2002b), ou seja, um processo dinâmico, que promove a experiência desafiadora da alteridade, sendo por essência, portanto, dialógico.

O desafio a ser enfrentado pelas BUs, no país, inscreve-se na compreensão do seu papel como dispositivos de apropriação cultural, remetendo, em decorrência, à consideração dos contextos socio-históricos e igualmente ao seu papel de formação cultural, em permanente diálogo com as demais esferas que constituem a ordem universitária.

Como "espaços institucionalmente legítimos" (Flickinger, 2011) e integrantes do processo de formação cultural universitária/acadêmica, a BU configura um dispositivo de relação com a memória cultural, com o patrimônio científico, artísticoliterário, mobilizado pelo pensamento, pela imaginação, criatividade dos sujeitos, tal como se referiu Möllmann, ao falar sobre Bildung como "movimento" de sair de si, de "distanciamento" e de "retorno". 


\section{Biblioteca universitária e estrutura acadêmica: análise de diretrizes}

Para entender as tendências que orientam o desenvolvimento de bibliotecas universitárias enquanto organismos de formação cultural, objeto da presente pesquisa, comparando discursos presentes nas diretrizes que orientam essas bibliotecas, selecionamos três universidades paulistas, indicadas no Times Higher Education.

Times Higher Education é uma instituição fundada no Reino Unido, em 2004, que fornece avaliação das universidades do mundo anualmente. Essa avaliação leva em consideração treze indicadores de desempenho, a saber: relação docentes/alunos; relação doutorandos/bacharéis; relação doutorandos/docentes; relação artigos/docente; relação citação/artigos; prestígio da pesquisa; prestígio do ensino; proporção de estudantes estrangeiros; proporção de docentes estrangeiros em regime integral; porcentagem de artigos em coautoria internacional; receita institucional; financiamento competitivo de pesquisa; e receita proveniente da indústria (METRICAS.EDU, 2020).

Esses indicadores abrangem as principais atividades das universidades, a saber: ensino, pesquisa, transferência de conhecimento e perspectivas internacionais e estão agrupados em cinco áreas:

- Ensino (o ambiente de aprendizagem)

- Pesquisa (volume, renda e reputação)

- Citações (influência da pesquisa)

- Perspectivas internacionais (funcionários, estudantes e pesquisa)

- Renda da indústria (transferência de conhecimento)

A escolha do Times Higher Education para selecionar as instituições a serem analisadas deu-se em razão, justamente, da multiplicidade dos eixos considerados, 
aspecto que coloca em igualdade as universidades tomadas como corpus de análise.

Além disso, para se proceder à análise das diretrizes, como dispositivo de interpretação, optou-se por utilizar a Análise de Discurso (AD), segundo os conceitos desenvolvidos por Eni P. Orlandi, em seu livro Análise de discurso, de 2005, que têm como base a escola francesa de AD. Para Orlandi (2005, p. 26), "a Análise do Discurso visa fazer compreender como os objetos simbólicos produzem sentidos, analisando assim os próprios gestos de interpretação que ela considera como atos no domínio simbólico pois eles intervêm no real do sentido".

Assim, a linha de análise adotada pretende trabalhar com o que Orlandi chama de de-superficialização, que consiste em estabelecer três eixos de abordagem: como se diz, quem diz, e em que circunstâncias. Nas palavras de Orlandi (2005, p. 26), "em suma, a Análise de Discurso visa a compreensão de como o objeto simbólico produz sentidos, como ele está investido de significância para e por sujeitos”.

\subsection{Universidade de Campinas (Unicamp)}

Na década de 1960, o governo do Estado de São Paulo estabeleceu o projeto de criação de uma escola de ensino superior e centro de pesquisas, no interior. $A$ criação da Unicamp se deu com a publicação do Decreto no 45.220, de 9 de setembro de 1965, que incorporava a Faculdade de Medicina de Campinas à recémcriada Unicamp, bem como estipulava o estatuto e outros regimentos da Universidade de São Paulo como diretrizes a serem usadas, até a criação de suas próprias normas.

Em 1966, Zeferino Vaz, reunido com empresários da região, define o perfil dos cursos que seriam implantados na universidade. No ano seguinte, a Faculdade de Odontologia de Piracicaba (SP) é incorporada à Unicamp; em 1969, a Faculdade de Engenharia de Limeira (SP) passa também a fazer parte da instituição (SERVIÇO DE ARQUIVO PERMANENTE DO ARQUIVO CENTRAL DA UNICAMP, 2020). Neste 
mesmo ano, o Decreto № 52.255 define o estatuto da Unicamp, elaborado pelo Conselho Diretor e, embora alguns artigos e parágrafos tenham sido revistos e atualizados, a base do estatuto permanece a mesma. Neste trabalho analisaremos a versão atualizada em março de $2019^{18}$.

É preciso lembrar que Zeferino Vaz foi reitor interventor na Universidade de Brasília ao mesmo tempo em que era presidente do Conselho Estadual de Educação de São Paulo, o que possibilitou que se desenvolvesse o projeto da Unicamp adiantando algumas características que seriam propostas na Reforma Universitária de 1968, como a estrutura organizacional, por exemplo. Além disso, a manutenção de reuniões entre a Comissão Organizadora da Unicamp e indústrias da região estabeleceu o vínculo entre a universidade e o parque industrial de Campinas.

Para Meneghel (2011, p. 258) a "interação da Unicamp com o meio externo, [...] iniciado em 1966, se manteve pela criação de diversas instâncias, com o interesse de manter a vinculação entre Universidade e setor produtivo", entre elas o CT (Centro Tecnológico), a Codetec (Companhia de Desenvolvimento de Tecnologia) e a Funcamp (Fundação de Desenvolvimento da Unicamp).

Meneghel também aponta a importância do estilo de gestão de Zeferino Vaz para a implementação da universidade nesse início. Nos primeiros anos, a Unicamp se firma como universidade de perfil tecnológico e de pesquisa, e que, pelos esforços de Zeferino, recebe pesquisadores do mundo todo. Ainda sobre esse período:

No início, não havia Colegiados, representações de Unidades, de docentes e de alunos. Zeferino concebia, propunha projetos e, conforme percebia a possibilidade de executá-los, implementava, sem muitas 'consultas'. Claro que isso era possível naquele momento, em plena Ditadura Militar. Como exemplo: o primeiro Concurso para funcionário da Unicamp ocorreu apenas em 1976. (MENEGHEL, 2011, p. 259)

Essa contextualização é importante, pois a primeira versão do estatuto da instituição é de 1969 e a do regimento geral é de 1974 e, embora com atualizações, a base ainda se mantém. É importante considerar as características administrativas de

18 É possível acompanhar as atualizações do estatuto pela página da Secretaria Geral da Unicamp. Disponível em https://www.sg.unicamp.br/autonomia-universitaria/documentos/\#collapse1. Acesso em 04 dez. 2020. 
Zeferino Vaz, uma vez que os fundamentos dessas diretrizes têm origem em sua gestão. Retomamos, então, um dos eixos da AD - o "quem diz" - inextricavelmente marcado pela posição que ocupa no todo social. Para Orlandi, (2005, p. 39) "o lugar a partir do qual fala o sujeito é constitutivo do que ele diz", ao que ela chama de "relação de forças".

Nesta seção usaremos como base de análise o Regimento Geral da Unicamp, atualizado em março de 2019, e a deliberação CONSU-A-015/2013, de 06/08/2013, que dispõe sobre o Regimento Interno do Sistema de Bibliotecas da Unicamp.

Artigo $1^{\circ}$ do Estatuto da Unicamp reafirma a "autonomia didático-científica, administrativa, financeira e disciplinar" (UNIVERSIDADE ESTADUAL DE CAMPINAS, 2019, p. 1), já estabelecida pela Lei Federal oㅜ 5.540/1968. A questão da autonomia universitária era um aspecto importante da reforma universitária da década de 1960, e que remonta ao modelo universitário alemão, apresentado anteriormente, para o qual o papel fundamental da pesquisa só é possível por meio da liberdade acadêmica:

\begin{abstract}
O anteprojeto dessa lei foi elaborado por um grupo de trabalho do qual fizeram parte os membros do Conselho Federal de Educação e professores universitários, todos versados no idealismo alemão. Esses protagonistas dos quais destaco Newton Sucupira e Roque Maciel de Barros, tinham nos filósofos da Universidade de Berlim farto manancial de ideias cuja fonte, todavia, permaneceu oculta. Particularmente, o messianismo universitário, a limitação da autonomia universitária pelo Estado e os princípios de organização da universidade, todos de Fichte, devem ter tido um papel central na formulação da doutrina da reforma universitária. (CUNHA, 2007, p. 20)
\end{abstract}

Embora abordasse os temas da autonomia universitária e da liberdade de ensino, a reforma universitária da década de 1960 sucumbiu aos interesses de uma elite conservadora. Florestan Fernandes denomina-a de "reforma consentida", pois não houve aprofundamento de questões centrais no processo educativo. Para ele, o fim do regime de cátedras foi um ponto positivo na legislação, porém ainda é possível ver resquícios dessa estrutura de manutenção de poder de um pequeno grupo. Ele aponta que o ensino superior fragmentado e com ênfase na formação de profissionais liberais deixa espaço reduzido para a pesquisa científica e que o ensino superior se ocupa de funções que poderiam ser do ensino médio. A lacuna entre o 
ensino e a pesquisa também é apontada pelo autor, para quem mesmo os setores responsáveis pela pesquisa, na verdade, se ocupam na maior parte do tempo de atividades de ensino e não de pesquisa.

Ao discutir a questão da autonomia universitária, Florestan Fernandes (2020, p. 345) defende que a reforma não tratou a universidade como "agente de uma vontade e de um destino próprios", e continua "as consequências são evidentes - a erosão e a perversão da autonomia universitária, mantida como recurso de retórica e como ficção legal inútil". Exemplo dessa afirmação é a nomeação de reitores e vicereitores pelo Presidente da República.

O texto também aponta uma diretiva humanista ao determinar como finalidade da universidade a "promoção do bem-estar físico, espiritual e social do homem" [sic]. Esse objetivo é reafirmado no item VI do artigo $2^{\circ}$, que propõe "desenvolver na comunidade universitária uma consciência ética, valorizando os ideais de pátria, de ciência e de humanidade". Assim, a universidade toma para si a missão de formar cidadãos conscientes, que contribuirão para o progresso da sociedade, além de auxiliar para o aperfeiçoamento da humanidade. Um aspecto que deve ser levado em consideração, tendo-se em vista a $A D$, é a circunstância em que se diz, uma vez que esta também constitui o discurso. Desse modo, conceitos de ética, de valorização dos "ideais de pátria" tomam um outro significado, se analisados na perspectiva da época em que a Unicamp é fundada (período da ditadura militar). Por conseguinte, a identificação com ideais da pátria, que incluem a adesão a um conjunto de regras de conduta, passa a ter a função de controle de uma ordem social imposta, de conformação ou de repressão daqueles que estão fora dessa ordem.

Porém ainda nesse artigo $2^{\circ}$, são propostas outras ações:

I. ministrar o ensino para a formação de pessoas destinadas ao exercício das profissões liberais, técnico-científicas, técnico-artísticas, de magistério e aos trabalhos desinteressados da cultura;

II. promover e estimular a pesquisa científica e tecnológica e a produção de pensamento original no campo da Ciência, da Tecnologia, da Arte, das Letras e da Filosofia; 
III. estudar os problemas sócio-econômicos da comunidade com o propósito de apresentar soluções corretas, sob a inspiração da democracia;

IV. pôr ao alcance da comunidade, sob a forma de cursos e serviços, a técnica, a cultura, e o resultado das pesquisas que realizar;

V. valer-se dos recursos da coletividade, tanto humanos como materiais, para integração dos diferentes grupos técnicos e sociais na Universidade;

VI. cumprir a parte que the cabe no processo educativo de desenvolver na comunidade universitária uma consciência ética, valorizando os ideais de pátria, de ciência e de humanidade. (UNIVERSIDADE ESTADUAL DE CAMPINAS, 2019, p. 1)

Embora o texto saliente o aspecto do "bem-estar físico, espiritual e social", a preocupação com a formação profissional e técnica toma vulto maior no documento, uma vez que além de não explicitar o que seria esse bem-estar, a questão da formação profissional e técnica é recorrente no documento, seja para caracterizar as unidades formadoras da Unicamp (institutos, faculdades), como aparece nos artigos 5o e 6ㅇ (UNIVERSIDADE ESTADUAL DE CAMPINAS, 2019), seja para descrever os tipos de cursos oferecidos (artigo $17^{\circ}$ ). Este é um ponto importante no que diz respeito às bibliotecas, uma vez que estas são órgãos de apoio e dão suporte bibliográfico aos cursos, coloca-se ênfase na atualização de seus acervos, uma atualização que deve ser constante, posto que a área da técnica e da tecnologia se renova a cada dia. Por outro lado, as diretrizes não trazem a questão da memória cultural e como as bibliotecas devem se posicionar com relação a isso. A seguir, ao analisarmos o regimento do sistema de biblioteca, veremos como se dá essa relação com os acervos, categoria relativa ao que chamamos de patrimônio cultural científico.

Ainda, a questão da formação profissional e técnica, em uma sociedade desigual como a nossa, deixa antever aspectos de cunho neoliberal, pois forma mão de obra especializada para o mercado, e como diz Pereira (2008, p. 48) "a lógica da tendência utilitarista da universidade tende a reduzir a construção do conhecimento a mera produção de conhecimento mercadológico". As pressões que a lógica de mercado imprime em todas as esferas da sociedade também se aplica ao estudante, que é entendido mais como força de trabalho do que como atuante no processo de formação. 
A referência à formação profissional está presente no artigo 19², que trata dos cursos de graduação, que são segmentados em dois ciclos:

$\S 1^{\circ}$. O primeiro ciclo terá caráter seletivo em relação aos ciclos ulteriores e, com esse objetivo geral, revestir-se-á das seguintes condições:

1. promover, tanto quanto possível, a recuperação de falhas evidenciadas pelo concurso vestibular, no perfil de cultura dos alunos, e que possam ser corrigidas a curto prazo;

2. orientar para a escolha da carreira;

3. ministrar conhecimentos básicos para um ou mais ciclos de formação acadêmica ou profissional;

4. propiciar elementos de cultura geral susceptíveis de serem desenvolvidos ao longo da graduação;

5. supervisionar o ensino de disciplinas específicas de formação profissional que tenham sido sugeridas pelos Institutos e pelas Faculdades e aprovadas pelo Conselho Universitário, mediante prévio parecer da Câmara de Ensino, Pesquisa e Extensão.

$\S 2$. O segundo ciclo atenderá à formação profissional específica. (grifo nosso) (UNIVERSIDADE ESTADUAL DE CAMPINAS, 2019, p. 3-4)

Ao falar em correção de falhas "no perfil de cultura dos alunos", em um primeiro momento já se pressupõe uma lacuna, um desnível entre o estudante que adentra a universidade e a comunidade acadêmica já estabelecida e consolidada. Por outro lado, o que o vestibular pode "evidenciar" seria uma falha (hiato) com relação a conteúdos, e que seria passível de correção num curto prazo, ou seja, não há a ideia de processos contínuos para além do período na universidade. Outro ponto a se considerar é a ideia de falha cultural, ou seja, considera-se falha aquilo que diverge de uma ordem simbólica hegemônica preestabelecida, o que não deixa espaço para alteridades, nem de diálogos entre diferenças.

Na sequência, o artigo 23ํㅜ que trata da pós-graduação, também traz a questão da formação profissional:

$\S 1^{\circ}$. O Mestrado visará a enriquecer a competência científica e profissional dos graduados, podendo ser considerado como nível terminal ou como eventual etapa do Doutoramento. 
$\S 2^{\circ}$. O Mestrado Profissional visará a formação e a atualização de profissionais em suas técnicas de trabalho, com maior abrangência e aprofundamento do que nos cursos de Aperfeiçoamento. (UNIVERSIDADE ESTADUAL DE CAMPINAS, 2019, p. 4)

Ao abordar o mestrado, em suas duas categorias, percebe-se tratar-se de uma outra etapa da formação, que visa o aprimoramento da mão de obra qualificada, visto que o aspecto profissional está em foco nessas categorias. Para além disso, a competência científica tratada como fator a ser enriquecido pressupõe que este processo tenha sido iniciado na graduação, e que seja uma das falhas do perfil cultural a ser corrigida.

Apenas no parágrafo $3^{\circ}$, que trata do Doutorado, indica-se a possibilidade de formação científica e cultural, que é ao mesmo tempo "ampla e aprofundada".

§ 3‥ O Doutorado visará a proporcionar formação científica e cultural, ampla e aprofundada, desenvolvendo a capacidade de pesquisa independente e 0 poder criador em determinado ramo do conhecimento. (UNIVERSIDADE ESTADUAL DE CAMPINAS, 2019, p. 4)

Uma vez que as diretrizes não explicitam uma definição de cultura, pode-se pensar que é uma definição implícita, ou o que Orlandi chamou de esquecimento número dois, ou da enunciação, aqui o "modo de dizer não é indiferente aos sentidos" (2005, p. 35). O não explicitar um significado de cultura já traz em si um conceito. A falha a ser corrigida no ingresso da graduação não tem mais lugar nesta etapa, aqui a formação passa a ter outros aspectos, científico e cultural: nessa esfera, o estudante está sendo formado para fazer parte dessa elite acadêmica, ou seja, é conhecedor de um conjunto de conhecimentos e práticas que o iguala aos outros pertencentes na ordem vigente.

\subsubsection{Das Bibliotecas da Unicamp}

Em 2003, a deliberação, CONSU-A-30 revisa o regimento das bibliotecas e da biblioteca central existente até então e cria o Sistema de Bibliotecas da Unicamp, configurado como órgão complementar da universidade. Seu regimento é aprovado em 2005 e depois revogado pela Deliberação CONSU A-15, de 06/08/2013. 
Por esta última deliberação, o sistema passa a ser composto pelo Órgão Colegiado, pela Coordenadoria, pelas Bibliotecas do sistema e pelas Comissões de Bibliotecas das Unidades de Ensino e Pesquisa, Centros e Núcleos.

Ao analisarmos 0 artigo 1을 do regimento deparamo-nos com um aspecto importante de sua criação. Neste artigo, o sistema de bibliotecas é definido como órgão complementar da universidade. Queremos, aqui, discutir o termo complementar. Um dicionário de sinônimos traz os seguintes termos como equivalentes a "complementar": acessório, dependente, dispensável, integrante, secundário, suplementar, episódico, acidental, extraordinário, ocasional (COMPLEMENTAR, 2020). Esse caráter de algo secundário e até mesmo dispensável fica evidente quando se observa que o Sistema de Bibliotecas não consta da listagem de órgãos complementares do próprio regimento da Unicamp.

Ao analisar um sistema que é órgão complementar ao mesmo tempo em que não está listado como tal, vamos retomar alguns conceitos trabalhados na $A D$, por Orlandi. Com base em Pêcheux, a autora nos traz a categoria de "esquecimento", usando o que denomina de esquecimento ideológico (ou número um), resultante da força da ideologia, que nos afeta passando a fazer parte do nosso inconsciente. Com este tipo de esquecimento, nós voltamos para "sentidos preexistentes" (p. 35); para ela, o esquecimento faz "parte da constituição dos sujeitos e dos sentidos", sendo, por isso, estruturante.

Então, temos um sistema de bibliotecas que em seu documento constitutivo se define como complementar, acessório, secundário; e que no contexto de sua instituição é "esquecido" ou "não-dito". 
Figura 2 Órgãos complementares - Unicamp

\section{CAPITULO III. DOS ÓRGÃOS COMPLEMENTARES}

Artigo 10. Os Órgãos Complementares são os seguintes:

I. Centro de Informação e Difusão

Cultural;

II. Editora Universitária;

III. Centro de Computação;

IV. Centro de Bioterismo;

V. Prefeitura da Cidade Universitária;

VI. Centro de Lógica, Epistemologia e História da Ciência;

VII. Centro de Ensino de Linguas.

$\S 1^{\circ}$. As entidades referidas neste Artigo ficam subordinadas à Reitoria.

$\S 2^{\circ}$. Os Órgãos Complementares reger-se-ão pelos Regimentos das entidades a que estiverem subordinados.

Artigo 11. A Universidade poderá, a juizo do Conselho Universitário, criar novos Órgãos Complementares e fundir, extinguir e alterar a vinculação dos já existentes.

Artigo 12. Com a finalidade de ampliar o ensino e a pesquisa, a Universidade poderá, mediante aprovação da Câmara de Ensino, Pesquisa e Extensão ou da Câmara de Administração, estabelecer convênios de natureza cientifica, técnica, didática e cultural com outras instituições públicas ou particulares.

Fonte: UNIVERSIDADE ESTADUAL DE CAMPINAS, 2019.

O Centro de Informação e Difusão Cultural começou como Órgão de coordenação da Biblioteca Central, na década de 1980. Posteriormente dará origem ao sistema de bibliotecas e ao sistema de arquivos (SIARQ) e será extinto pela Deliberação CONSUA-039/1989, de 20/12/1989.

Começa-se, assim, a vislumbrar como se dá essa relação entre um sistema de bibliotecas acessório em uma instituição de ensino e centro de pesquisas. Os documentos mostram que a relação das bibliotecas com o ensino se dá pela oferta de seus acervos, enfatizando-se o desenvolvimento das coleções e a disseminação e divulgação de seus itens. 
O sistema, então, apresenta em seu artigo $1^{\circ}$ as seguintes finalidades:

I - dar suporte às atividades de ensino, pesquisa e extensão;

II - definir a política de desenvolvimento dos diferentes acervos que compõem as bibliotecas da Universidade;

III - possibilitar à comunidade universitária e à comunidade científica o acesso à informação armazenada e gerada na UNICAMP;

IV - promover intercâmbio de experiências e acervos. (UNIVERSIDADE ESTADUAL DE CAMPINAS, 2013)

Como vimos na seção em que discutimos os conceitos de BU, sua finalidade está em consonância com os objetivos/missão da universidade da qual faz parte. A Unicamp se coloca como finalidade a "promoção do bem-estar físico, espiritual e social do homem", o que não vimos como fins do seu sistema de bibliotecas. Se, como dissemos anteriormente, as BUs são parte das políticas e culturas do universo acadêmico do qual fazem parte, parece que há um descompasso entre os discursos presentes no regimento da universidade e no regimento do sistema de bibliotecas.

Embora considerando distinções entre o papel da universidade, mais abrangente do ponto de vista social, e o papel da BU (que também tem um caráter social), é preciso levar em conta o fato de a BU constituir-se dispositivo cultural, cujo foco são as relações simbólicas com o patrimônio cultural letrado, o patrimônio infodocumentário.

Ao analisarmos os três últimos itens das finalidades expostas, observamos a ênfase atribuída aos acervos, seja em relação ao seu desenvolvimento, seja na sua divulgação, deixando evidente a prioridade aos repositórios. O regimento da Unicamp traz de forma marcante a questão da formação profissional, técnica, para a qual as BUs dão suporte, por meio de seus acervos, segundo a diretriz analisada. $O$ desenvolvimento de coleções está submetido, então, às características dessa formação proposta pela universidade, priorizando, em princípio, a atualização constante dos repositórios. Não há, entretanto, menção a possíveis trabalhos a serem considerados em relação a esses acervos, tendo em vista os grupos que deles fazem (ou deveriam fazer) uso, deixando a critério dos profissionais tais deliberações. 
A questão dos usos passa a ser problemática na medida em que os circuitos de produção e de recepção são fragmentados, seja em razão da ordem cultural, seja em função da explosão da informação/conhecimento. Os sujeitos, enquanto tal, não têm condições de dar conta de conhecer a produção e, portanto, sua participação nesse universo simbólico é afetada. O circuito cultural de origem pesa nesse processo e numa universidade massificada, que inclui, mas não prepara efetivamente, o sujeito está à deriva. Por isso, a posição crítica em relação à information literacy, porque deixa o sujeito à mercê dessa massificação, tendo que aprender à força a se tornar information literate por meio de algumas atividades na biblioteca.

A deliberação Consu-A-015/13 não menciona quais mecanismos as BUs têm, ou se poderiam criá-los, para lidar com essa lacuna que interfere nos processos de apropriação simbólica. A diretriz é omissa em relação à inclusão desses sujeitos no universo simbólico que integra memória cultural científica:

Além disso, o artigo 4ํapresenta como competências do sistema de bibliotecas:

I - adotar padrões ou critérios de organização e administração de sistemas de informação;

II - elaborar e encaminhar à Administração da Universidade sua proposta orçamentária;

III - executar o orçamento gerindo recursos financeiros, tanto orçamentários quanto de outras fontes;

IV - emitir parecer sobre aquisição de material bibliográfico para a Universidade;

V - emitir parecer, quando solicitado, sobre ingresso e seleção de profissionais e auxiliares da área, bem como afastamentos para participação em eventos e cursos afins;

$\mathrm{VI}$ - promover o aperfeiçoamento dos profissionais integrantes do SBU;

VII - realizar a incorporação de todos os materiais bibliográficos adquiridos para o SBU, inclusive através de convênios, e torná-los acessíveis;

VIII - cadastrar e disseminar a produção técnico-científica gerada na Universidade, assessorando quanto à apresentação técnica das publicações; 
IX - integrar-se a sistemas nacionais e internacionais de informação, visando o acesso e a divulgação da produção técnico-científica gerada pela Universidade. (UNIVERSIDADE ESTADUAL DE CAMPINAS, 2013)

A análise das competências do sistema confirma o exposto anteriormente, ou seja, que o sistema, e as bibliotecas por conseguinte, é representado como agente administrador de acervos, em que fica evidente a preocupação com a salvaguarda de itens, principalmente da produção técnico-científica da universidade, aspecto sem dúvida essencial de todo sistema de bibliotecas, uma vez que é de sua incumbência preservar o patrimônio e a produção intelectual existente. Entretanto, além da conservação, as ações complementares limitam-se à divulgação e disseminação dessa produção, silenciando-se acerca de processos de mobilização desse patrimônio a favor da formação cultural e científica de seus quadros.

Ao continuarmos a análise da deliberação Consu-A-015/13, percebemos que ela se ocupa em definir a estrutura do sistema de bibliotecas, elencando seus órgãos e suas competências. Fica evidente sua configuração hierárquica, em que o órgão superior é o seu colegiado, o qual delibera sobre questões de "manutenção e desenvolvimento dos recursos do Sistema" (UNIVERSIDADE ESTADUAL DE CAMPINAS, 2013). Esse órgão também tem como competências uma série de atividades em torno das políticas e do planejamento do sistema, os quais serão implementados pela coordenadoria do sistema.

Ao ser adotada configuração hierárquica, o sistema de bibliotecas também trabalha com as questões de autonomia nas tomadas de decisão, aspecto recorrente nos debates sobre a universidade, mas que neste quadro não foram evidenciadas. Um dos pontos relacionados à questão da autonomia é referente à escolha do coordenador do sistema, o qual é indicado pelo reitor, como expresso no artigo $12^{\circ}$, parágrafo único, impossibilitando, assim, que a própria comunidade escolha sua coordenação. Embora a escolha do reitor para a coordenadoria do sistema se dê entre os profissionais bibliotecários que já tenham ocupado cargos de direção nas bibliotecas da Unicamp, o que poderia assegurar a competência técnica, a coordenação também pode ser vista como cargo político, negociado entre grupos alinhados. Este é um dos aspectos acerca da autonomia: a autonomia dos 
processos participativos, cuja principal contribuição pode ser a escuta sensível e atenta às realidades e contextos localizados.

Outro aspecto é o que diz respeito à possibilidade de as BUs traçarem suas políticas, seus programas e ações em torno de princípios da apropriação cultural, sem que imposições restritivas existam em virtude da estrutura hierárquica do sistema.

Seguindo essa estrutura, temos as bibliotecas que formam o SBU. O Regimento Interno do SBU destina apenas três artigos (artigos $17^{\circ}, 18^{\circ}$ e $19^{\circ}$ ) para tratar das bibliotecas. Os artigos tratam tanto da delimitação de bibliotecas que formam o sistema, como de sua subordinação técnico-administrativa, passando por suas finalidades e competências.

E mais uma vez vemos surgir como finalidade a "disseminação da informação e a divulgação de seu acervo", bem como a preocupação com o desenvolvimento de acervos, padrões e normas:

Artigo 18 - Compete às bibliotecas do SBU:

I - promover o desenvolvimento da coleção de acordo com as necessidades específicas de cada área;

II - integrar-se aos padrões, normas de serviços e atividades do Sistema;

III - identificar os perfis de seus usuários e assegurar o atendimento de suas necessidades de informação;

IV - propor projetos de interesse a serem desenvolvidos pelo SBU;

V - promover a disseminação da informação e a divulgação de seu acervo. (UNIVERSIDADE ESTADUAL DE CAMPINAS, 2013)

O regimento do sistema trata das questões técnicas e administrativas, mas não discute o papel educacional/educativo/cultural das bibliotecas dentro da universidade, ou seja, como e se participariam para a concretização da "promoção do bem-estar físico, espiritual e social do homem", diretiva humanista apresentada como finalidade da Unicamp em seu estatuto. 
Embora estipule-se como papel da Unicamp o desenvolvimento de uma consciência ética, os itens não estabelecem claramente a participação das bibliotecas para alcançar esse objetivo. Parece que aqui fica evidente o que é entendido por órgão complementar, uma vez que essas bibliotecas são tomadas como organismos acessórios para a formação de sujeitos éticos, cidadãos e livres. Nesse sentido, o olhar crítico sobre um discurso que confere caráter residual à BU articula-se a possibilidade potencial desses organismos como articuladores do diálogo intercultural constitutivo da formação ética, entendida como preceito que determina a ação dos indivíduos, visando "o máximo de harmonia, universalidade, excelência ou perfectibilidade, o que implica a superação de paixões e desejos irrefletidos" (ÉTICA, 2009). Em uma palavra, de cidadãos, ou seja, indivíduos capazes de exprimirem-se de acordo com sua vontade e consciência e que usufruem de direitos, desempenham deveres e respeitam as liberdades.

Em seu Estatuto, mostra-se com peso a ideia de formação de quadros profissionais, bem como a promoção do bem-estar físico, espiritual e social, porém as diretrizes relativas às bibliotecas não especificam os respectivos recursos ou metodologias usados para este fim.

Para além de serem guardiãs de acervos, de preocuparem-se com seu desenvolvimento, difusão e divulgação de informações científicas, o discurso em torno dessas bibliotecas, tal como se observa nos documentos, oferece poucos subsídios objetivos que a ancorem na articulação entre ensino e informação. A análise dos documentos, ao mostrar que o modelo difusionista prevalente contribui pouco no atendimento de necessidades de comunidades acadêmicas que não fazem mais parte de um mundo de sujeitos "já iniciados", de uma elite, que culturalmente é capaz de fazer suas escolhas, que tem capacidade de julgamento do patrimônio existente, deixando às bibliotecas e bibliotecários a difícil tarefa de enfrentamento de um sistema em esgotamento, pois não está preparado para lidar com outra ordem de questões que afetam processos de apropriação simbólica no quadro universitário. Por sua característica, o referido modelo irá privilegiar a democratização cultural, categoria que, no quadro de massificação cultural a que as populações de modo geral estão submetidas, acaba por suprimir, em razão de 
determinada ordem acadêmica, as diferentes experiências culturais como elementos mobilizadores dos diálogos com o patrimônio cultural acadêmico acumulado.

Enquanto organismo educativo, a essencialidade da biblioteca universitária reside, assim, no desenvolvimento de condições e processos que permitam aos sujeitos a atribuição de significados à memória cultural científica, patrimônio indissociável às dinâmicas próprias à construção de conhecimento.

\subsection{Universidade de São Paulo (USP)}

A Universidade de São Paulo foi fundada em 25/01/1934, pelo Decreto Estadual ํo 6.283/34, assinado pelo interventor Armando de Salles Oliveira. Para Hey e Catani, (2011), a criação dessa universidade integrava o plano político paulista que pretendia formar uma elite dirigente, bem como o desenvolvimento cultural e a investigação científica. O objetivo de formação de uma elite fica expresso no Decreto no $6.283 / 34$ :

[...] considerando que a formação das classes dirigentes, mormente em países de populações heterogêneas e costumes diversos, está condicionada à organização de um aparelho cultural e universitário, que ofereça oportunidade a todos e processe a seleção dos mais capazes. (SÃO PAULO, 1934)

Para Cunha (2007a, p. 22), a fundação da USP, ao reunir professores europeus, "propiciou condições para que se formasse um novo modelo de cientista, que veio a representar importante papel no processo de institucionalização da ciência brasileira", a ser concretizado, conforme Souza (1996, p. 54), por meio de projeto que caracterizava a USP como uma universidade "liberal de inspiração inglesa e francesa, autônoma, livre, estatal, colegiada, departamentalizada e opositora ao Governo Federal".

A proposta inicial de uma universidade que formaria dirigentes "capazes de ultrapassar a visão profissional e técnica restrita que caracterizava os cursos superiores dominantes até então" (HEY E CATANI, 2011, p. 235) entra em choque, 
todavia, com a proposta das escolas que privilegiavam a formação para exercício de profissões, tais como Direito, Engenharia e Medicina.

Os mesmos autores ainda apontam impedimentos à realização desse modelo original, em menos de uma década de existência da universidade. O que se seguiu, até a década de 1960, foram "movimentações no sentido de ajustes organizacionais ao lado de mudanças no estatuto legal da universidade [...] Ao longo das décadas de 50 e 60 a instituição vai trilhando um caminho em que se reforça sua autonomia administrativa" (HEY E CATANI, 2011, p. 237).

Segundo Cunha (2007), durante a ditadura militar, a USP organizou uma comissão de reestruturação, em razão do Decreto-lei no 53/66, que fixava princípios e normas de organização para as universidades federais. A comissão produziu um relatório, apresentado em junho de 1968, e que ficou conhecido como relatório Ferri. Segundo Celeste Filho (2017), a reforma universitária de 1968 possibilitou o debate de diversas propostas de reorganização de suas estruturas e que, todavia, não eram consensuais. Uma vez que a reitoria não determinou de que maneira esse debate se daria nas unidades, cada uma delas adotou seus próprios métodos. Assim, algumas criaram comissões paritárias de docentes e discentes, outras criaram comissões paritárias das três categorias, docentes, discentes e funcionários; enquanto outras unidades "simplesmente ignoraram o comunicado do reitor e do Conselho Universitário" (CELESTE FILHO, 2017, p. 205).

Os debates promovidos pelas unidades tinham como objetivo formular propostas de reestruturação, por vezes, antagônicas: institutos interdependentes x faculdades autônomas; currículos flexíveis x organização curricular profissional prioritária; universidade integrada $x$ universidade conglomerada (CELESTE FILHO, 2017). A proposta de transformar as unidades universitárias em institutos interdependentes foi derrotada no Conselho Universitário às vésperas da votação da Lei nº 5.540/68 que instituía a reforma universitária. Segundo o autor, "sucumbia aí o cerne das propostas inovadoras da Universidade de São Paulo" (2017, p. 228). Com a decretação do Al-5, em 1968, a reestruturação da Universidade de São Paulo é interrompida. Para o autor: 
A reforma da USP efetivamente executada pode ser resumida na extinção das cátedras e no desmembramento da sua Faculdade de Filosofia, Ciências e Letras para a formação de institutos básicos. Em 1969, a Comissão de Ensino Pesquisa e Extensão - CEPE - assumiu algumas das atribuições propostas para a Câmara Curricular. Contudo, incumbindo-se a CEPE de muitas outras responsabilidades, diluiu-se seu propósito exclusivo de organização dos cursos da USP. Isto impossibilitou a dinâmica de flexibilização dos currículos concebida para a Câmara Curricular. As funções da CEPE não foram nem pálida sombra do que se propunha com a articulação das diversas comissões de ensino na Câmara Curricular. Consequentemente, a integração universitária e a flexibilidade curricular, das quais um dos pilares seria a Câmara Curricular, foram mais uma vez abortadas. (CELESTE FILHO, 2017, p. 228)

Para Hey e Catani (2011, p. 239-240), as reformulações na USP tiveram como principais efeitos: a escolha do reitor por professores de maior titulação acadêmica; "a rejeição quase absoluta dos estudantes nos conselhos e assembleias de caráter decisório"; passou-se a reconhecer o caráter específico do ensino técnico e da pesquisa aplicada; além disso, "os cursos de pós-graduação são instituídos como cursos regulares e com dispositivos uniformes para toda a universidade, com organização curricular e um sistema de créditos e de notas, modelados ao estilo norte-americano".

Ainda para os autores, nas últimas décadas do século $X X$, consolidou-se o afastamento do modelo original de universidade. Houve ampliação do número de vagas em cursos de graduação e pós-graduação, criação de novos cursos, implementação de serviços de extensão, além da "consolidação da pesquisa científica de padrão internacional" (2011, p. 240). Eles continuam e observam que outras reformas no estatuto da USP trouxeram algumas modificações, tais como "gradativa instalação de fundações privadas no interior da universidade, a ampliação constante da captação de recursos externos, a concentração de poder de seus dirigentes universitários e de alguns órgãos colegiados" (2011, p. 240).

Nesta seção utilizaremos para análise o Estatuto da Universidade de São Paulo, baixado pela Resolução oㅜ 3.461 , de 7 de outubro de 1988, que embora tenha tido atualizações pontuais de artigos e parágrafos ao longo dos anos, ainda é o estatuto em vigor. 
O artigo 1ำ do Estatuto traz a questão da autonomia universitária, definindo a USP como autarquia "com autonomia didático-científica, administrativa, disciplinar e de gestão financeira e patrimonial", condição já garantida anteriormente pela Lei Federal $n^{\circ}$ 5.540/1968, posteriormente atualizada pela Lei oㅜ 9.394/1996, para em seguida apresentar suas finalidades, sendo elas:

I - promover e desenvolver todas as formas de conhecimento, por meio do ensino e da pesquisa;

II - ministrar o ensino superior visando à formação de pessoas capacitadas ao exercício da investigação e do magistério em todas as áreas do conhecimento, bem como à qualificação para as atividades profissionais;

III - estender à sociedade serviços indissociáveis das atividades de ensino e de pesquisa. (UNIVERSIDADE DE SÃO PAULO, 1988)

Esses três itens denotam a importância do papel da pesquisa nas atividades da universidade, o que nos leva mais uma vez ao modelo universitário alemão, para o qual a pesquisa está atrelada à liberdade acadêmica. Em suas finalidades, os pontos centrais giram em torno de atividades, principalmente as de pesquisa, cujo objetivo se coloca como a formação de mão de obra, seja como pesquisadores, professores ou profissionais qualificados, mas sem evidenciar a formação de cidadãos conscientes e de pensamento crítico. Fernandes (2020, p. 127) aborda a questão da pesquisa no ensino superior discutindo que a "dimensão criadora" foi colocada à margem da pesquisa pelo ensino superior, pois seu objetivo principal "estava na profissionalização", assim, "o único tipo de pesquisa que encontrava algum sentido dentro dela era irrelevante como foco de produção original do saber".

Embora, em seu artigo $3^{\circ}$ se denomine como universidade pública "aberta a todas as correntes de pensamento" regida por princípios de "liberdade de expressão, ensino e pesquisa", na prática, os mecanismos socioculturais filtram e direcionam os quadros ingressantes, entre outros aspectos, pela relação candidato-vaga e formação prévia nas áreas de conhecimento. Da mesma forma a questão da permanência estudantil e qualidade dessa permanência implicam mecanismos que interferem na aprendizagem e na apropriação do conhecimento, e que se refletem até sobre aspectos somáticos da vida do estudante. 
Para alcançar seus objetivos, a instituição se organiza em Unidades, Museus, órgãos de Integração e órgãos Complementares, conforme estipulado no artigo 4ํㅡㄹ ou seja, o Estatuto da USP não cita bibliotecas como dispositivos atuantes para o cumprimento de seus objetivos. O parágrafo único, do artigo $4^{\circ}$, diz: "As Unidades, os Museus, os órgãos de Integração e os órgãos Complementares serão discriminados no Regimento Geral" (UNIVERSIDADE DE SÃO PAULO, 1988). Neste Regimento, todavia, observa-se que as bibliotecas não são definidas nem como órgãos de integração nem como complementares. Recorrendo mais uma vez à $A D$ e à categoria do esquecimento ideológico, esquecimento estruturante, trata-se de esquecimento significativo, pois a omissão se faz presente no documento principal da universidade, fundante da instituição, e que não revela o caráter de suas bibliotecas, apenas citando sua existência.

Nesses termos, enquanto o Estatuto da USP (1988) não faz nenhuma menção sobre suas bibliotecas, o Regimento Geral (1990) faz uma única referência, sobretudo em perspectiva organizacional, em seu artigo 253ํ, vinculando o Sistema Integrado de Bibliotecas da USP (SIBI) à Reitoria (UNIVERSIDADE DE SÃO PAULO, 1990). Sob a ótica do quadro hierárquico da universidade, fica delegado ao sistema e suas bibliotecas uma série de questões em torno de seus papéis dentro da universidade e perante a comunidade, mas com todas as limitações que essas diretrizes de "esquecimento" impõem.

\subsubsection{Das Bibliotecas da USP}

O Sistema de Bibliotecas da USP (SIBI) foi criado em 1981 pela Resolução no 2.226, da reitoria da USP. Resolução sucinta, em seu primeiro artigo fica criado o SIBI; no segundo, define-se qual a função do sistema, ou seja, centralizar "as informações bibliográficas, tendo em vista o ensino, a pesquisa e a extensão de serviços à comunidade"; o artigo $3^{\circ}$ determina que o Conselho Universitário será o responsável por decidir as normas que regeriam o sistema; e o último artigo põe em vigor a resolução. 
Em 1989, a Resolução $\mathrm{n}^{\circ}$ 3.571, baixada pela reitoria da USP, altera e consolida o Regimento do SIBi. Embora não mais em vigor, destacaremos alguns itens que dizem respeito ao papel da biblioteca na universidade.

Em seu artigo $1^{\circ}$, a Resolução determinava o objetivo do SIBi: "criar condições para o funcionamento sistêmico das bibliotecas da USP, a fim de oferecer suporte ao desenvolvimento do ensino e pesquisa" (UNIVERSIDADE DE SÃO PAULO, 1989).

A resolução ainda trazia uma definição de biblioteca, a saber:

[...] define-se como Biblioteca integrada ao Sistema o órgão que conta com, no mínimo, um Bacharel em Biblioteconomia, com função de Bibliotecário, zelador do acervo Bibliográfico e artístico e Coordenador de consultas e empréstimo. (UNIVERSIDADE DE SÃO PAULO, 1989)

Por esse texto, vimos a ideia que se tinha de biblioteca universitária, uma biblioteca de suporte, cujo bibliotecário é um "zelador de acervo" "guardião", definição adotada para caracterizar bibliotecários medievais.

Passando à análise da Resolução № 5.776, de 2009, que baixa o novo regulamento do SIBi, coloca-se que o objetivo do sistema é "criar condições para o funcionamento sistêmico das Bibliotecas da USP, a fim de oferecer suporte ao desenvolvimento do ensino e pesquisa" (UNIVERSIDADE DE SÃO PAULO, 2009), ou seja, o mesmo em duas décadas de sua existência. Interessa-nos, sobretudo, abordar o aspecto da Resolução que especifica a estrutura do sistema, dividido em Conselho Supervisor; Departamento Técnico e Conjunto de Base, determinando como cada um será constituído.

Antes de nos determos na análise do conjunto de base, do qual fazem parte as bibliotecas, vale destacar que o parágrafo $3^{\circ}$ do artigo teve sua redação alterada pela Resolução no $5.846^{19}$, de 2010, o que aparentemente tirava a obrigatoriedade de o diretor técnico ser um dos bibliotecários do sistema. A medida tornaria possível a escolha abrangente dentro do quadro da universidade - um docente, por exemplo - gerando certa dubiedade ao se comparar com o disposto no capítulo seguinte.

19 onde antes lia-se "O Reitor escolherá o Diretor Técnico do SIBi/USP, dentre os Bibliotecários responsáveis por Bibliotecas das Unidades da USP", passou-se a ler "O Reitor escolherá o Diretor Técnico do SIBi/USP", 
Neste, em referência ao Departamento Técnico, está determinado em seu artigo 4ํㅜ, que a direção do Departamento ficará a cargo de um Bacharel de Biblioteconomia, subordinado ao reitor. Essa mudança parece ser evidência de uma contraposição entre categoria docente e não-docente, o que retiraria 0 caráter técnico da nomeação, e permearia com um peso político a escolha para o cargo.

O capítulo III tratará do conjunto de base, que é composto pelas bibliotecas da

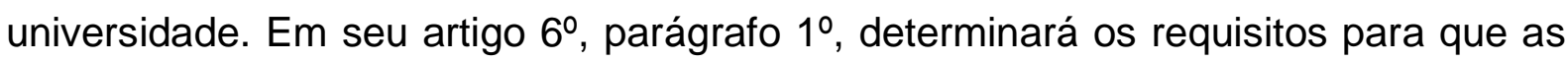
bibliotecas sejam parte do SIBi, a saber:

I - possuir, no mínimo, em seu quadro funcional, um servidor, Bacharel em Biblioteconomia, com função de Bibliotecário, devidamente registrado no Conselho Regional de Biblioteconomia, bem como dois técnicos de nível médio ou um técnico de nível médio e um de nível básico;

II - contar com um acervo de, no mínimo, cinco mil itens entre livros, periódicos, teses e dissertações, vídeos e mapas, devidamente organizados e acessíveis ao público por meio de catálogos (manuais ou eletrônicos), com conteúdo relevante à missão da Unidade ou órgão a que esteja vinculado;

III - disponibilizar o mínimo de três computadores conectados à rede USP, sendo dois para os usuários;

IV - ocupar uma área física de, no mínimo, 400 metros quadrados e ter horário de atendimento de, no mínimo, oito horas diárias. (UNIVERSIDADE DE SÃO PAULO, 2009)

Este artigo define a biblioteca universitária prioritariamente como acervo (coleção) e conjunto de itens técnicos para seu funcionamento, a partir de perspectiva sobre a sua dimensão material, ressaltando aspectos quantitativos. Considerando-se a referência ao conceito de dispositivo, anteriormente discutido, a ausência de menção, no regimento, a aspectos semiológicos e pragmáticos que caracterizam a biblioteca revelam um entendimento raso sobre seu potencial de construção de relações dos sujeitos com o patrimônio cultural documentário, essencial à mobilização do conhecimento. Essa questão se inscreveria na dimensão educativa das bibliotecas, questão que parece esvaziada, mesmo em se tratando de dispositivo constitutivo de sistema de ensino superior. 
Dispondo sobre as competências e atribuições das partes integrantes do sistema, está estabelecido que ao Conselho Supervisor cabe avaliar assuntos ligados às atividades do sistema; aprovar o plano anual e o relatório de atividades do sistema. Porém, pelo exposto nesse artigo, o Conselho Supervisor não propõe políticas ou planos para o sistema, ou ações educativas, confirmando seu alinhamento a modelo de oferta informacional que caracteriza a biblioteca tradicional.

Cabe à Diretoria Técnica a coordenação e implantação do planejamento estratégico do sistema; bem como a garantia de dispor informação em diferentes suportes; fortalecimento de ações com instituições internas e externas à USP. Um item interessante é o que propõe "implementar as políticas estabelecidas pelo Conselho Supervisor nas áreas de automação, aquisição de coleções; tratamento e disseminação da informação, preservação e conservação dos acervos e capacitação de equipes do SIBi/USP” (UNIVERSIDADE DE SÃO PAULO, 2009).

Nessas considerações reafirma-se o hiato entre o sistema educativo docente e a estrutura técnica bibliotecária. A articulação entre as duas esferas não está prevista. Nem o quadro docente tem visão desse hiato, nem o campo bibliotecário consegue explicitar o papel educativo essencial da biblioteca, o que alimenta, portanto, sua representação como apoio ao ensino, apesar de vivermos numa era em que a produção informacional acadêmica tenha ganhado centralidade nos processos de formação superior.

\subsection{Universidade Federal de São Paulo (Unifesp)}

A Universidade Federal de São Paulo (Unifesp) tem sua origem com a fundação da Escola Paulista de Medicina, em 1933, que no princípio contava com recursos privados e "subsídios governamentais até a federalização em 1956" (Universidade Federal de São Paulo, 2014). A história da Escola Paulista de Medicina (EPM) permite o entendimento da configuração da Unifesp, atualmente. 
A criação da EPM se deu pela ação conjunta entre alguns jovens profissionais, na sua maioria médicos, e um grupo de egressos do vestibular da Faculdade de Medicina de São Paulo, em 1933. Octávio de Carvalho toma à frente da iniciativa e utiliza-se de seu capital político e social "para viabilizar um empreendimento privado para o qual confluíram interesses vinculados à expansão do ensino médico, da pesquisa científica e das redes de saúde pública" (NEMI, 2008, p. 104). Basicamente, foi uma confluência de interesses: de um lado a demanda por mais vagas para o curso de Medicina em São Paulo, de outro a demanda por acesso a cátedras em cursos de Medicina.

Segundo Nemi (2008), a fundação da EPM faz parte de um momento de transição entre o "catedrático antigo, erudito distante da pesquisa, e o cientista moderno, voltado para a elaboração e resolução prática de problemas" (p. 103). Segundo a autora, a fundação da Escola incorpora ao ensino e à pesquisa a "experiência do trabalho em institutos de pesquisa" (p. 103). Será interessante observar essa dimensão pragmática do ensino superior (não necessariamente universitário) que agrega um traço importante para pensar a biblioteca, o pesquisador e a cultura acadêmica e profissional.

Nessa perspectiva pragmática, já no ano seguinte da sua fundação, a EPM encaminha ao MEC os documentos para pedido de reconhecimento da Escola, o qual teria como requisito primordial a prática clínica.

De 1934 até 1938, alguns financiamentos se sucedem, tanto para aquisição de imóvel como para início da construção do hospital. No final da década 1930, em razão da falta de regularização no pagamento desses financiamentos acontecem as primeiras discussões sobre a federalização da Escola. Segundo Nemi:

a rapidez com que foi tocado o empreendimento de uma escola médica, aliado à construção de um novo hospital, exigia que fossem contraídas dívidas significativas. Chegaria o tempo em que a articulação entre o capital político e social dos membros e colaboradores da Escola, os interesses das elites estaduais reconfiguradas após 1930, os interesses do Governo Federal diante do estado irredento e as facilidades colocadas pelas alterações na política econômica nacional, não seriam mais suficientes para continuar materializando as idéias em edificações concretas. (NEMI, 2008, p. 113) 
Embora as dificuldades financeiras fossem uma realidade, em 1938, foi autorizada a instalação de um curso de Enfermagem Obstétrica ligado ao Hospital São Paulo. E em 1942, a Escola de Enfermeiras do Hospital São Paulo é reconhecida oficialmente (UNIVERSIDADE FEDERAL DE SÃO PAULO, 2017), a qual mais tarde passará a se chamar Escola Paulista de Enfermagem (EPE).

Esses fatos, inscritos na história institucional, auxiliam a entender um dos aspectos que elegemos para análise de nosso objeto de pesquisa, baseado no conceito de de-superficialização da AD: o quem diz.

Pelos fatos expostos até aqui, depreendemos algumas características da instituição. Trata-se de órgão que em sua origem se organiza em torno de quadros da elite paulista, seja na esfera de seu corpo discente, uma vez que os estudantes provinham de famílias abastadas, com recursos para pagar por seus estudos, bem como de mantê-los durante o período; seja na de seu no corpo docente, formado por médicos e pesquisadores de outras instituições que migram para a EPM, e que também colaboravam financeiramente para a manutenção da escola em seus primeiros anos. Articulado aos encaminhamentos, por vezes voluntaristas, para sua manutenção, ressalta-se também o caráter privado da instituição, o que não impediu que recebesse verbas, principalmente, federais, demonstrando a força do capital político dos quadros da EPM.

Em janeiro de 1956, a Lei № 2.712 federaliza a Escola Paulista de Medicina, incorpora à União os bens e propriedades da Escola, bem como efetiva os professores catedráticos, reduzindo as cátedras a dezoito.

A federalização propiciou as discussões em torno da criação de uma universidade federal em São Paulo. Assim, em 1961, é criada a Universidade Federal de São Paulo (UFSP), a partir da incorporação da Escola Paulista de Medicina, Escola de Engenharia de São Carlos; Faculdade de Filosofia, Ciências e Letras de Araraquara; Faculdade de Farmácia e Odontologia de Araçatuba e Faculdade de Economia de Santo André. Segundo Biondi, existia um grupo majoritário de docentes da EPM 
contrário "à progressiva expansão e transformação da EPM em universidade federal" (2008, p. 144).

Se por um lado a reforma educacional, que fazia parte das reformas de base propostas pelo governo de João Goulart, encontrava resistência e oposição do corpo docente da escola, por outro fazia eco aos anseios dos estudantes da EPM, que viam na transformação da escola em universidade uma maneira de se inserirem de forma completa ao mundo universitário. Com o golpe de 1964, entretanto, foram revogados os decretos que instauravam a UFSP. Assim, em outubro de 1964, a Escola Paulista de Medicina se desliga da Universidade Federal de São Paulo, que deixa de existir. Posteriormente, porém, o movimento ressurge e, em 1994, com a lei 8.957, que a Escola Paulista de Medicina se transforma em Universidade Federal de São Paulo, desta vez Unifesp.

Segundo Rodrigues (2008), “a expansão só seria consubstanciada a partir de 2005 num sinal claro de que tal processo não vinha sendo planejado de forma sistemática até aquela efeméride" (p. 207). Para o autor, o título de universidade de saúde marca a implementação dos primeiros cursos decorrentes da expansão do começo do século XXI.

Nesta seção vamos analisar o Estatuto Geral, de 2011, em que já constavam alguns dos chamados campi da expansão.

Em seu primeiro artigo, o Estatuto indica a lei federal que dispõe sobre a transformação da Escola Paulista de Medicina em Universidade Federal de São Paulo. A memória institucional da EPM é marcante no começo do Estatuto:

§ 1ํ A Unifesp decorre da transformação da Escola Paulista de Medicina, fundada em $1^{\circ}$ de junho de 1933, federalizada pela Lei $n^{\circ} 2.712$, de 21 de janeiro de 1956, e transformada em estabelecimento isolado de ensino superior de natureza autárquica pela Lei oㅜ 4.421, de 29 de setembro de 1964. (UNIVERSIDADE FEDERAL DE SÃO PAULO, 2011)

Segundo a $A D$, o funcionamento dos discursos é um jogo da memória: de um lado temos aquilo que se estabiliza e cristaliza, e de outro aquilo que é esquecido. Ao tornar presente ainda hoje a EPM como cerne da Unifesp, institui uma relação de 
poder que pende para setores mais antigos e conservadores da universidade. Como diz Orlandi, "de um lado, é na movência, na provisoriedade, que os sujeitos e os sentidos se estabelecem, de outro, eles se estabilizam, e cristalizam, permanecem" (2005, p. 10).

Como nas outras instituições analisadas, a questão da autonomia universitária também se faz presente logo no início do Estatuto, estando presente no Artigo 1ำ $\S$ $2^{\circ}$, e citando a autonomia didático-científica, administrativa e de gestão financeira e patrimonial, estabelecida pela Lei Federal nํ⒌540/1968.

O artigo $2^{\circ}$ traz a finalidade da instituição, ou seja, "desempenhar com excelência atividades indissociáveis de ensino, pesquisa e extensão". Também aponta em que condições essas atividades serão oferecidas. Destaca-se os termos "condições adequadas" e "condições de excelência". Indica, ainda, que os cursos de graduação formariam "profissionais qualificados para atuarem na sociedade de maneira crítica e reflexiva" (art. $2^{\circ}, \S 2^{\circ}$ ).

Com relação às atividades de extensão, define que esta deve prestar serviços à comunidade, "por meio do desenvolvimento de programas e projetos sociais e da realização de cursos, eventos e campanhas públicas" (art. 2ํㅗํํำ).

Ao tratar da estrutura organizacional, determina que as bibliotecas são órgãos complementares, e define os objetivos desses órgãos:

Art. 6ํㅡ A Universidade poderá ter órgãos complementares integrados à sua estrutura organizacional, os quais terão por objetivo colaborar na execução, difusão e expansão das atividades de ensino, pesquisa e extensão e serão organizados por área de atuação. (UNIVERSIDADE FEDERAL DE SÃO PAULO, 2011) 
Como esta é a única menção às bibliotecas no Estatuto ${ }^{20}$ e no Regimento Geral da Unifesp, pretendemos que a análise dos documentos relativos à sua coordenadoria forneça os elementos para compreender como a BU é aí representada.

\subsubsection{Da Coordenadoria da Rede de Bibliotecas da Unifesp (CRBU)}

O Regimento Interno da Coordenadoria da Rede de Bibliotecas da Unifesp determina que esta é "responsável pela gestão sistêmica das bibliotecas da UNIFESP", participando das atividades de ensino, pesquisa e extensão da Universidade, definindo como suas atribuições:

I - coordenar o desenvolvimento das atividades da rede de bibliotecas da Universidade, criando condições para seu funcionamento sistêmico;

II - servir de apoio aos programas desenvolvidos na Universidade, proporcionando colaboração técnica por meio da rede de bibliotecas;

III - propor políticas compatíveis com o planejamento estratégico da Unifesp, que atendam às necessidades de informação bibliográfica e da produção científica e cultural da Universidade;

IV - integrar-se a sistemas nacionais e internacionais de informação, visando o acesso e a divulgação da produção técnico-científica gerada pela Universidade;

$\mathrm{V}$ - propor e estabelecer diretrizes, normas e procedimentos para a rede de bibliotecas;

VI - defender a promoção do acesso e disseminação da informação, assim como o desenvolvimento e intercâmbio da rede e das suas unidades;

VII - analisar e propor melhorias tecnológicas e procedimentais continuamente, de acordo com as necessidades das bibliotecas, de seus serviços e de sua comunidade. (UNIVERSIDADE FEDERAL DE SÃO PAULO, 2016)

20 A versão do Estatuto analisada nesta dissertação é a que estava em vigor em 2018, quando fizemos a coleta dos documentos. Houve um processo de discussão e atualização desse Estatuto, que se iniciou em 2014. O novo Estatuto, que entrou em vigor em junho de 2020, não mais considera as bibliotecas como órgãos complementares, nem menciona as bibliotecas ou a coordenadoria da rede de bibliotecas como parte da estrutura organizacional da Unifesp, muito menos define seu papel, missão ou objetivos. Novo Estatuto está disponível em: https://unifesp.br/images/docs/consu/resolucoes/2020/Resolu\%C3\%A7\%C3\%A30_183_Estatuto_ TextoFinal_23089.101867_2020_14.pdf Acesso em: 03/11/2020. 
A seguir o documento passa a definir a estrutura da coordenadoria, elencando seus órgãos, suas competências e atribuições: Conselho Deliberativo; Departamento Técnico; Bibliotecas Universitárias.

Figura 3 Organograma da CRBU

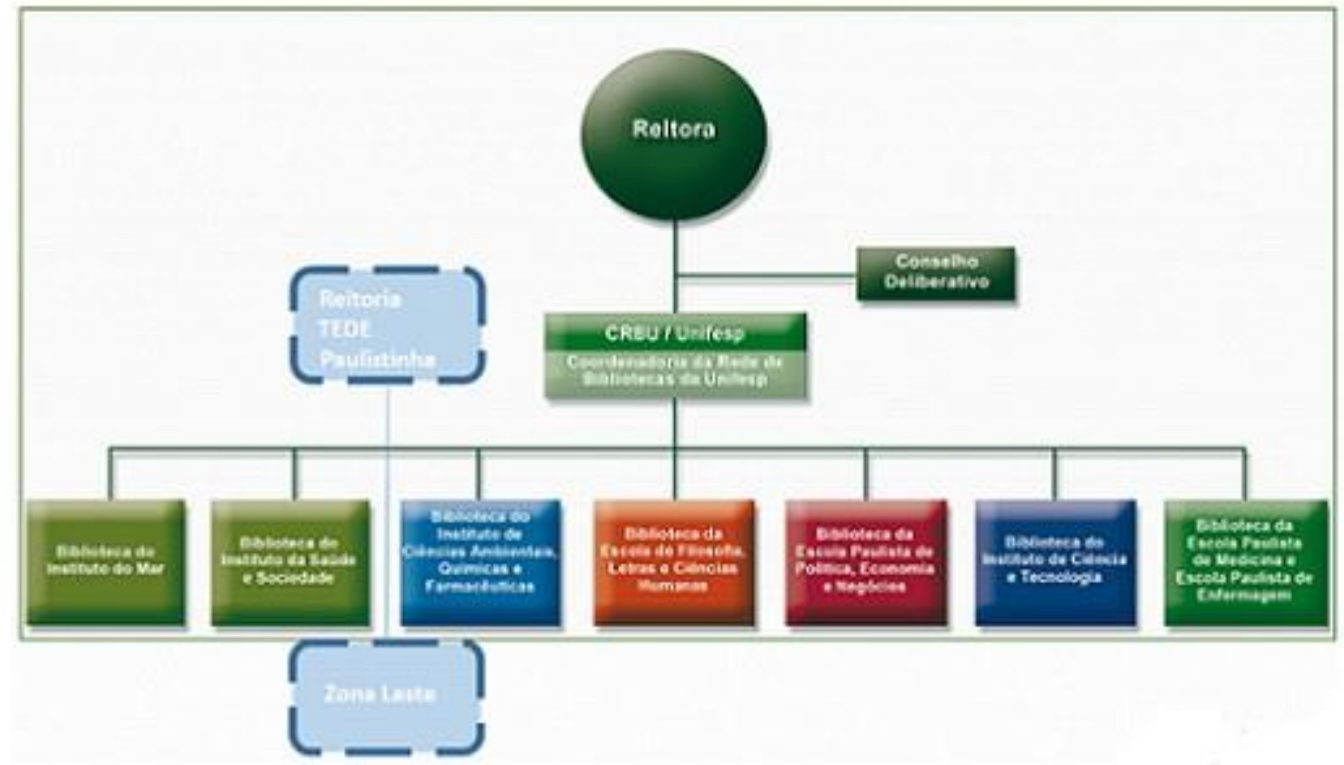

Fonte: UNIVERSIDADE FEDERAL DE SÃO PAULO, 2020 (b).

Pelo estabelecido, o Conselho Deliberativo é caracterizado como órgão máximo deliberativo da Coordenadoria e decide sobre as políticas de manutenção e desenvolvimento da Coordenadoria. Também é responsável pela aprovação de projetos de implantação de novas bibliotecas.

Trata, então, do Departamento Técnico e suas divisões, a saber: Diretoria; Divisão de Tecnologias de Informação; Divisão de Comunicação, Disseminação e Acesso à Informação; Divisão de Projetos e Pesquisas; Divisão de Gestão Sistêmica; Divisão de Formação e Desenvolvimento de Coleção; Divisão de Processamento e Tratamento da Informação. 
A CRBU foi criada em 2013 e em novembro de 2020 ainda não se teve a implantação da estrutura proposta em seu regimento, documento este que foi elaborado por representantes bibliotecários de cada campus e aprovado pelo Conselho Universitário, órgão deliberativo máximo da universidade, fato evidenciado pela análise da composição da equipe que forma a CRBU, como apresentado na figura a seguir.

Figura 4 Equipe que compõe a CRBU

\section{Coordenadoria}

Maria Eduarda dos Santos Puga

Diretora

Norma Shizue Moriama Iwashita

Diretora Adjunta

\section{Equipe}

Andrea Akemi Oribe Hayashi

Cristiane de Melo Shirayama

Juliana Almeida dos Santos

\section{Colaboração técnica}

Andrezza de Santana Moreira

Flávio Castro de Souza

William José Sobral

Fonte: UNIVERSIDADE FEDERAL DE SÃO PAULO, 2020 (a).

O levantamento do histórico dos fatos institucionais da Unifesp faz ressaltar, em vários momentos, uma característica acerca do modo como os eventos se sucedem, sem necessariamente estarem em planejamento prévio, articulado organizadamente. Como em muitos contextos brasileiros, a situação se repete nesse 
quadro, ou seja, um projeto é implantado, com bons resultados, e em consequência passa a mobilizar outras iniciativas, muitas vezes sem ancoragem suficiente para sua estabilidade. Ao transpor essa questão para o sistema de bibliotecas, percebese que durante quase uma década o desenvolvimento da CRBU não foi previsto, tendo em vista alcançar a estrutura proposta em seu regimento. A contraposição entre o regimento e quadro organizacional da rede traz à tona a dimensão do esquecimento ideológico, proposto por Orlandi (2005), que retoma "sentidos preexistentes" (p. 35), ou seja, uma ideologia de apagamento em relação aos dispositivos culturais, que passa pelo esvaziamento do seu sentido no quadro universitário, e que se objetiva na própria estrutura da rede que não conseguiu ser constituída e consolidada.

Esse esquecimento institucional que se traduz, à primeira vista, de forma mais evidente, pela falta de estrutura, também é corroborado, e corrobora, a falta de elementos que orientem ações em torno da BU; sejam eles de ordem política ou técnica. Em outros termos, esse esquecimento é fortalecido pela falta de referências que defendam o valor essencial da BU na formação de quadros no ensino superior.

Ao trazermos para esta situação a importância da autonomia universitária como diferencial atrelado à construção de conhecimento, e que repetidas vezes não se concretiza de fato porque está sujeita a uma série de cobranças e pressões externas, retomamos a ideia de Fernandes (2020), para quem, em tais situações, a tal autonomia passa a ser uma ficção. Ou seja, a autonomia institucional só existirá se os meios para a estruturação do sistema de bibliotecas, para seu crescimento e desenvolvimento existirem. Caso contrário, condena-se, assim, este sistema ao desaparecimento, o que já está em curso nos regimentos institucionais.

Nesta seção vamos nos concentrar no Capítulo III do Regimento, que dispõe sobre as bibliotecas universitárias da rede.

Primeiramente, o documento lista as bibliotecas integrantes da rede e, em seguida, define suas responsabilidades: a "organização, ampliação e manutenção do acervo 
impresso e digital", bem como "o serviço de referência e (...) treinamento dos usuários".

$\mathrm{O}$ art. $23^{\circ}$ determina que as bibliotecas dos campi estão vinculadas tanto à diretoria do respectivo campus como à diretoria da $\mathrm{CRBU}$, e estabelece as responsabilidades de cada uma em relação às bibliotecas, a saber:

$\S 1^{\circ}$ a diretoria deve prover infraestrutura adequada para o funcionamento das bibliotecas, bem como manutenção predial, serviços de limpeza, segurança, recursos humanos e financeiros.

$\S 2^{\circ}$ a responsabilidade técnica da CRBU é averiguar que todas as atividades e desenvolvimento das bibliotecas estejam de acordo as normas necessárias para atender com qualidade e excelência conforme indicadores adotados. (UNIVERSIDADE FEDERAL DE SÃO PAULO, 2016, p. 11)

Mais adiante, em seu art. 27ํㅡ, estabelece as competências das bibliotecas, apresentadas a seguir:

I - respeitar e aplicar as diretrizes da CRBU;

II - atender às necessidades de informação da comunidade acadêmica, devendo assegurar a difusão de informações culturais e científicas e o desenvolvimento das políticas da CRBU;

III - ser recurso educacional para o desenvolvimento dos trabalhos acadêmicos desenvolvidos e publicados na Universidade;

IV - manter recursos bibliográficos nas áreas de cultura geral e de livros constantes nos planos de curso;

V - oferecer apoio aos programas e projetos educacionais da Universidade;

VI - conservar, divulgar e facilitar o acesso dos usuários ao seu acervo;

VII - organizar, conservar e disponibilizar o acervo sob sua responsabilidade, de acordo com as normas vigentes;

VIII - proceder ao controle e execução das verbas orçamentárias e recursos financeiros da Biblioteca;

IX - promover o acesso às fontes internas e externas de informação;

X. - orientar os usuários na apresentação de monografias, teses e trabalhos científicos em geral, de acordo com as normas técnicas vigentes;

XI - providenciar a manutenção das áreas físicas, instalações e equipamentos da Biblioteca; 
XII - enviar relatórios anuais para a Diretoria da CRBU, contendo as atividades realizadas pela Biblioteca no período abordado. (UNIVERSIDADE FEDERAL DE SÃO PAULO, 2016, p. 12)

Trata-se de lista de amplo espectro, repertoriando competências que incluem desde a manutenção da infraestrutura das bibliotecas, à orientação de usuários, além de tornar as bibliotecas um recurso educacional, aspecto não considerado nos documentos anteriores. Embora esse aspecto não seja da competência do regime, ressaltamos que não há outra diretriz referente às bibliotecas em sua totalidade, o que existe são os regimentos de cada unidade, aspecto que se interpõe ao desenvolvimento de perspectiva de uma instância ampla, constituída como categoria educacional (e não mero recurso), deixando margens para concepções isoladas de cada biblioteca.

Ainda em seu artigo $27^{\circ}$, parágrafo $1^{\circ}$, determinará os requisitos para que as bibliotecas sejam parte da CRBU, a saber:

I - possuir, no mínimo, em seu quadro funcional, um servidor, Bacharel em Biblioteconomia, com função de Bibliotecário, devidamente registrado no Conselho Regional de Biblioteconomia, bem como dois técnicos de nível médio ou um técnico de nível médio e um de nível básico;

II - contar com um acervo de, no mínimo, cinco mil itens entre livros, periódicos, teses e dissertações, vídeos e mapas, devidamente organizados e acessíveis ao público por meio de catálogo online compatível com o sistema vigente, com conteúdo relevante à missão da Unidade ou órgão a que esteja vinculado;

III - disponibilizar o mínimo de três computadores conectados à rede da UNIFESP, sendo dois para uso de usuários;

IV - ocupar uma área física de, no mínimo, 500 metros quadrados e ter horário de atendimento de, no mínimo, oito horas diárias. (UNIVERSIDADE FEDERAL DE SÃO PAULO, 2016, p. 13)

O Regimento da CRBU também determina a estrutura organizacional das bibliotecas por setores, a saber: Coordenação de Biblioteca; Seção de Referência / Circulação; Seção de Processamento Técnico; Seção de Gestão de Biblioteca. Além disso, estabelece as competências de cada setor.

À Coordenação da biblioteca compete as atividades de implementação de políticas da rede; bem como planejamento, organização e coordenação das atividades da 
biblioteca, entre outras atribuições que fariam da Coordenação uma ligação entre a biblioteca e as outras instâncias da universidade, por exemplo, "representar a biblioteca universitária em reuniões da CRBU, Comissão local de bibliotecas e outras quando solicitado, para que haja uma melhor integração das bibliotecas com os demais setores responsáveis pelas atividades-fim da Universidade".

Os artigos que tratam das seções de Referência e de Processamento Técnico delimitam as atividades desses setores no espectro de atividades técnicas, entre as palavras mais citadas nessas competências estão "organizar" e "manter".

Já à seção de Gestão de Biblioteca compete atividades relacionadas ao apoio administrativo, manutenção da infraestrutura e condições de trabalho da biblioteca.

A análise das competências das bibliotecas demonstra uma preocupação com atividades técnicas, que têm o acervo como objetivo principalmente. Também nesta instituição as bibliotecas são tidas como órgãos complementares, que embora tenham como objetivo colaborar na "execução, difusão e expansão das atividades de ensino, pesquisa e extensão", não são proponentes de políticas institucionais que efetivassem ações concretas. 


\section{BIBLIOTECA UNIVERSITÁRIA E FORMAÇÃO CULTURAL: REPRESENTAÇÕES DOS DISCURSOS}

Nos discursos dos documentos selecionados para análise, buscamos destacar elementos que subsidiassem a reflexão sobre as relações BU e formação cultural, questão que perpassa processos de apropriação simbólica e produção de conhecimento.

Em termos institucionais, os estatutos universitários se mostraram documentos para gestão, definindo o organograma administrativo do estabelecimento de educação, sem alusão ao papel educacional específico da BU.

Alguns aspectos se evidenciaram nos textos, a saber: a questão da autonomia universitária, os sistemas de bibliotecas como parte da estrutura administrativa, bibliotecas como órgãos complementares e as características desses dispositivos, que de acordo com nossa interpretação privilegiam o foco da difusão de acervos como apoio ao ensino.

Abordagem pragmática, de caráter técnico, as representações de BU mostraram-se limitadas e limitantes nos discursos. Reforçando posições acerca da relevância cultural da BU, fazemos referência a Hall (1997), acerca da centralidade da cultura, categoria que, segundo o autor, permeia todos os aspectos da vida social, "mediando tudo" (p. 22). Para ele, o fato de atribuirmos sentido a tudo faz com que todas as práticas sociais sejam práticas de significação, e isso define o lugar da cultura nas instituições e nas relações em sociedade.

Assim, encontraremos nos discursos analisados indícios das representações sobre o papel atribuído às BUs, tomadas como práticas sociais implementadas por essas instituições, discursos estes que constroem significados tanto por aquilo que expressam quanto por aquilo que omitem. 


\subsection{Biblioteca universitária: sistemas e autonomia}

Tema central em todos os documentos abordados, a autonomia universitária constitui conceito que perpassa a história das dessas instituições e que se define, nas palavras de Cunha (2006), como "a luta pela difusão e o desenvolvimento do saber, sem constrangimentos externos" (p. 14).

No Brasil, conforme o autor, embora o termo autonomia comece a figurar nos debates sobre ensino superior ainda na década de 1910, é só com o Estatuto das Universidades Brasileiras, de 1931, que se estabelece padrões de organização para as instituições de ensino superior, os quais determinavam como se daria a escolha de diretores, conselhos universitários e reitores, processos na prática, todavia, não isentos de interferências, o que leva Cunha a considerá-los como mecanismos de cooptação, pois promoviam tão somente autonomia relativa para as universidades, sobretudo em períodos políticos de exceção, pelos quais o país passou.

A lei 5.540, de 1968, lei da Reforma Universitária, embora reconhecesse a autonomia como elemento das universidades, também trazia mecanismos que limitavam essa autonomia. Ainda hoje, vemos a atuação desses mecanismos, nos modos de nomeação de reitores, que rompem com protocolos acordados colegiadamente, por exemplo.

De modo transversal a questão da autonomia afeta os sistemas de bibliotecas universitárias, configurações recorrentes nos organismos, na medida em que os grandes conglomerados acadêmicos lançam mão dessa modalidade como forma de economia de recursos, eficácia de processos pela padronização de procedimentos, ou seja, pelo estabelecimento de parâmetros únicos a serem seguidos pelas unidades subordinadas. Em relação ao órgão central, os sistemas de bibliotecas das três universidades apresentam uma configuração hierárquica, subordinado às reitorias, apresentando estrutura hierarquizada de seus colegiados e bibliotecas formadoras do sistema. 
Por adotarem uma estrutura hierárquica, os sistemas de bibliotecas organizam-se de forma a terem uma centralização de poder mais ou menos alta, a depender do nível de submissão de suas estruturas nas tomadas de decisão. A lógica exige atenção com relação à representatividade e participação, tanto das bibliotecas que formam o sistema, como da comunidade como um todo.

Por terem como funções primordiais o acesso e uso de informações registradas bem como a produção de novos conhecimentos, atendendo às necessidades institucionais de ensino e pesquisa, os sistemas estão baseados em lógica cujo cerne está na formação especializada de um estudante "ideal", o usuário de biblioteca integrante, todavia, de quadros humanos heterogêneos, em grande parte sem o domínio dos códigos que regem a ordem acadêmica em suas diferentes instâncias e esferas. Inscritos em modelos hierárquicos, os sistemas são presididos pela manutenção da lógica que lhes é inerente, tendendo a desconsiderar as diferentes pontas, ou antes, sendo impermeáveis a elas. As bibliotecas, enquanto pontas desse sistema, estão espremidas entre os mecanismos hierárquicos e a lógica de seus cotidianos, cabendo a elas a busca de alternativas para o enfrentamento dessa espécie de crise entre o pressuposto educativo, nem sempre explícito, com suas dinâmicas e singularidades, e a monologia de uma ordem informacional alimentada por seus próprios princípios.

\subsection{Biblioteca universitária: órgãos complementares e esquecimento institucional}

As diretrizes inscritas nos documentos fundantes dessas três instituições apresentam a figura do "órgão complementar". O termo complementar ${ }^{21}$ refere-se a adjetivo que qualifica um objeto como dispensável, secundário. Designação aplicada

21 Ao pesquisar em dicionários de termos jurídicos (LUZ \& SOUZA, 2015; SIDOU, 2016) não encontramos definições para o termo "órgão complementar". Também não encontramos referência ao termo na Lei de Diretrizes e Bases da Educação. 
à existência da biblioteca universitária, nessas instituições, é evidente nos discursos das três universidades abordadas, e cuja recorrência é preocupante.

Utilizamo-nos da categoria que a $A D$ chama de esquecimento ideológico para entender a visão que essas três universidades têm de suas bibliotecas e sistemas. Como apontado, as bibliotecas quase não aparecem nos documentos fundadores dessas instituições, o que deixa antever como esse esquecimento afeta o conceito aplicado a esses bens simbólicos.

As bibliotecas e seus sistemas existem de fato, mas têm colocação secundária nos documentos analisados, perspectiva que implicitamente imprime nessas diretrizes papel menos relevante a essa natureza de prática cultural. O seu esquecimento por parte desses regimentos nos dá elementos sobre as representações atribuídas ao binômio formação-biblioteca nas instituições de ensino superior: dissociadas da centralidade dos processos educativos, designadas como complementares e inscritas nos patamares dos serviços administrativos, as bibliotecas universitárias são representadas como categoria residual que descompassa com sua efetiva ação acadêmica.

Assim, no contexto da sociedade da informação/sociedade do conhecimento com seus peculiares desafios, em especial aqueles vinculados aos processos de significação da informação, a atuação da BU preenche espaço cultural único como dispositivo de estabilização da ordem simbólica científico-cultural. Esse aspecto não está vislumbrado nos discursos legais e a inexistência de considerações nessa direção acaba retardando o reposicionamento do lugar da BU como dispositivo educativo em si, no ensino superior/universitário, não condicionado exclusivamente a aparato técnico-especializado. 


\subsection{Biblioteca universitária como dispositivo}

As bibliotecas universitárias não estão representadas de forma unívoca nos discursos das diretrizes das universidades, podendo-se identificar variáveis, mesmo de forma implícita.

A questão de preservação dos acervos está manifesta nos documentos das três instituições. Assim, os sistemas e suas bibliotecas se apresentam como administradores de acervos, a partir da inclusão de descrição de bibliotecário "zelador de acervo", "guardião", remetendo à existência da concepção de biblioteca templum, denominação criada por Perrotti para estabelecer e identificar paradigmas, associando a uma denominação de outras esferas sociais, aquela dos bibliotecários medievais.

Pelo histórico das instituições analisadas, vimos que elas nascem como instrumentos de elites como instituições restritas a grupos de iniciados, lógica que se estende às representações de bibliotecas, locais em que o saber deve ser conservado para usufruto de eleitos.

Por outro lado, concorre com tal representação a ideia de BU ligada à difusão do conhecimento, vistas como meras divulgadoras dos saberes acumulados pelo organismo. Os discursos dos documentos em vigor trazem à tona uma biblioteca que é centro distribuidor de produtos culturais, como prática que por si só atuasse na formação cultural dos sujeitos.

Em outros termos, a análise dos documentos mostra que ainda lidamos com o paradigma de biblioteca difusionista, permeado por elementos de conservação. Esse paradigma, todavia, é insuficiente para responder às novas necessidades e demandas das comunidades acadêmicas contemporâneas, marcadas por sérios hiatos culturais. Esta é uma realidade que se coloca: existe uma diversidade que se impõe na comunidade acadêmica, de estudantes cujas experiências com bibliotecas são mínimas, e cujo contato com dispositivos culturais e científicos se iniciará somente na universidade. Nesse aspecto, os estatutos universitários ao explicitarem 
como objetivo a gestão institucional, enquadram as bibliotecas, como parte de um organograma funcional, desprovido de dimensão educacional.

De modo geral, pelos regimentos, pouco se atualizou, ao longo de décadas, sobre as BUs, mantendo-se de forma ainda prevalente representações como instâncias tão somente de oferta informacional, discurso que não corresponde à dimensão educativo-cultural desses dispositivos, mas que, ao ser incluído pudesse, talvez, introduzir certo estranhamento saudável aos percursos a serem trilhados, na contemporaneidade. 


\section{Considerações}

O estudo partiu do pressuposto de que as bibliotecas universitárias como organismos integrados às instituições de ensino superior - institutos, faculdades e universidades -, constituem instância da mesma natureza dos organismos aos quais pertencem, em decorrência, orientadas por princípios capazes de inseri-las no circuito acadêmico de produção intelectual, científica e cultural, com objetivos educativos e trânsito pelas esferas dinamicamente articuladas do ensino, pesquisa e extensão, tripé que caracteriza a universidade pública, em nosso país.

A opção metodológica à abordagem da questão concentrou-se na análise de diretrizes institucionais que dão base às universidades e suas bibliotecas, na perspectiva de encontrarmos indícios das representações sobre o papel atribuído às BUs em discursos que constroem significados tanto por aquilo que expressam quanto por aquilo que omitem.

Como discutido, as bibliotecas e seus sistemas existem de fato, porém ocupam posição secundária, por vezes de instância administrativa, de acordo com o que revelam os documentos analisados. Assim, as representações atribuídas ao binômio formação-biblioteca nas instituições de ensino superior indicam a dissociação das BUs da centralidade dos processos educativos, uma vez que as são representadas como categoria residual (complementar) aspecto que, na ordem dos discursos, não explicita seu papel educativo intrínseco, fundamental à formação dos quadros acadêmicos para o diálogo com o patrimônio simbólico. Parece claro que as rupturas entre biblioteca e sociedade no país, que resultam em carência de experiências culturais diversificadas, próprias às vividas em bibliotecas públicas, e aprendizagens pertinentes aos objetivos das chamadas bibliotecas escolares, traz consigo entraves à apropriação das BUs como bens culturais, sinalizando dificuldades e fragilidades que remetem ao debate dos referidos discursos como forma de mobilizar reflexões sobre concepções, modos de funcionamento, finalidades e práticas culturais que orientam tais dispositivos em nossas universidades. 
O estudo mostrou que nas diretrizes consideradas (USP, Unicamp, Unifesp), tomadas como recorte indicativo da lógica que representa a BU na esfera universitária, esta está delimitada a instrumento técnico institucional, aspecto que chama a atenção quando se considera as carências que marcam as relações entre biblioteca e seus atuais públicos, seja em termos das problemáticas originadas pela nova ordem informacional contemporânea que vem determinando o valor e o caráter da informação, seja em razão do quadro socio histórico brasileiro marcado por cisões importantes com a cultura letrada e científica. Tais fenômenos, que afetam o contexto acadêmico, em nosso país, é terreno concreto e complexo a ser enfrentado pela $\mathrm{BU}$, a partir de evidências que sinalizem seus contornos identitários nos documentos que a descrevem.

Como organismo inscrito em instituição de ensino superior, é fundamental que a BU seja observada não somente como ambiente de informação, mas também como equipamento educativo, instância de mediação cultural do patrimônio cultural científico, implicando sujeitos e processos de criação de sentidos às dinâmicas de construção do conhecimento. Num país em que a relação com o patrimônio simbólico é frágil, tem que se ter claro que existe uma situação real e concreta de descontextualização com o conhecimento, que reflete em nós da mesma maneira, ou seja, produz pensamento fragmentário, alterando também a ordem do pensar e do significar.

Ao se apagar ou esquecer do papel educativo das bibliotecas universitárias, esvaziase 0 potencial desses dispositivos culturais enquanto espaços dialógicos, com complexo papel na formação cultural de toda a comunidade universitária. As diretrizes instituíram as competências técnicas de suas bibliotecas, a partir de parâmetros que não incluem especificamente os quadros aos quais se dedica, ou seja, as dimensões ética, estética, cognitiva e política da prática educativa.

Se, conforme discutido, as bibliotecas universitárias refletem suas instituições, em certa medida as universidades também reverberam suas bibliotecas. Assim, a própria universidade tem deixado à própria sorte esses sujeitos, e estão presas a 
esse paradigma, segundo o qual o conhecimento é encarcerado pelas políticas difusionistas.

A abordagem realizada permitiu evidenciar, assim, a urgência em se considerar a BU sob nova perspectiva, como categoria acadêmica de mediação cultural, tendo em vista a relevância de seu papel educativo afirmativo na formação de sujeitos que articulem saberes especializados a compreensões sobre seus significados sociais, atuando nas relações entre sujeitos e patrimônio cultural, como ambiente que favorece o diálogo, a construção de experiências significativas com a informação, a memória científica e cultural mais ampla, estabelecendo condições de vínculos com o universo dos signos. A formação cultural situada nesse horizonte, entretanto, implicará correlatamente concepções e metodologias ao enfrentamento da problemática que afeta a educação superior no país.

O presente estudo, nesse sentido, buscou oferecer contribuições para o debate da temática, visando salientar limitações acerca de abordagens procedimentais sobre a BU, esperando-se inscrever a questão em dimensão político-social. 


\section{REFERÊNCIAS}

ALVES, A. A tradição alemã do cultivo de si (Bildung) e sua significação histórica. Educação \& Realidade, Porto Alegre, v. 44, n. 2, e83003, 2019. Disponível em $<$ http://www.scielo.br/scielo.php?script=sci_arttext\&pid=S217562362019000200606\&lng=pt\&nrm=iso>. Acesso em: 20 jul. 2019.

AMERICAN LIBRARY ASSOCIATION. Definition of a Library: general definition: academic libraries. Disponível em: <https://libguides.ala.org/library-definition>. Acesso em: 05 jun. 2019

AMERICAN LIBRARY ASSOCIATION. Handbook. S. L, 1894. Disponível em: $<$ https://alair.ala.org/bitstream/handle/11213/493/ALAHandbook_1894.pdf?sequence $=1$ \&isAllowed $=\mathrm{y}>$. Acesso em: 02 abr. 2020 .

AMERICAN LIBRARY ASSOCIATION. Program of the twelfth general meeting. New Hampshire, 1890. Disponível em:

$<$ https://alair.ala.org/bitstream/handle/11213/429/ALAConference_1890.pdf?sequenc $\mathrm{e}=1$ \&isAllowed=y . Acesso em: 02 abr. 2020.

ASSOCIATION OF COLLEGE AND RESEARCH LIBRARIES. ACRL History. Disponível em: <www.ala.org/acrl/aboutacrl/history/history>. Acesso em: 02 abr. 2020.

ASSOCIATION OF COLLEGE AND RESEARCH LIBRARIES. ACRL Plan for Excellence. Disponível em: <http://www.ala.org/acrl/aboutacrl/strategicplan/stratplan>. Acesso em: 02 abr. 2020.

BARBIER, F. História das bibliotecas: de Alexandria às bibliotecas virtuais. São Paulo: Editora da Universidade de São Paulo, 2018.

BAUMAN, Z., RAUD, R. A individualidade numa época de incertezas. Rio de Janeiro: Zahar, 2018.

BIANCHETTI, L.; THIENGO, L. C. O Processo de Bolonha 1.0 e 2.0 e sua Globalização: implicações para a universidade. Educação, v. 43, n. 3, p. 413-430, jul./set. 2018. Disponível em:

<https://periodicos.ufsm.br/reveducacao/article/view/31933>. Acesso em 20 jul. 2021.

BIESTA, G. (a). Bildung and modernity: The future of Bildung in a world of difference. Studies in Philosophy and Education, v. 21, n. 4-5, p. 343-351, 2002.

BIESTA, G. (b). How General Can Bildung Be? Reflections on the Future of a Modern Educational Ideal. Journal of the Philosophy of Education, v. 36, n. 3, p. 377-390, 2002. 
BODLEIAN LIBRARIES. History of the Bodleian. Disponível em:

<https://www.bodleian.ox.ac.uk/about/history>. Acesso em: 02 abr. 2020.

BORGES, M. C. de A. Reforma da universidade no contexto da integração europeia: o processo de Bolonha e seus desdobramentos. Educ. Soc., Campinas, v. 34, n. 122, p. 67-80, jan.-mar. 2013. Disponível em: <http://www.cedes.unicamp.br>. Acesso em: 10 jul. 2021.

BOTO, C. Na Revolução Francesa, os princípios democráticos da escola pública, laica e gratuita: o Relatório de Condorcet. Educ. Soc., Campinas, v. 24, n. 84, p. 735-762, setembro 2003. Disponível em <http://www.cedes.unicamp.br>. Acesso em: 05 maio 2019.

BRANDALISE, G. C. M.; HEINZLE, M. R. S. Aspectos históricos e políticos do Processo de Bolonha: expansão de políticas de internacionalização na Educação Superior. Série-Estudos, Campo Grande, MS, v. 25, n. 54, p. 65-88, maio/ago. 2020.

BRASIL. Decreto no 19.851, de 11 de abril de 1931. Dispõe que o ensino superior no Brasil obedecerá, de preferência, ao systema universitario, podendo ainda ser ministrado em institutos isolados, e que a organização technica e administrativa das universidades. Rio de Janeiro, Disponível em:

<https://www2.camara.leg.br/legin/fed/decret/1930-1939/decreto-19851-11-abril1931-505837-publicacaooriginal-1-pe.html>. Acesso em: 29 jan. 2020.

BRASIL. INEP. Análise do documento "Repensar da garantia da qualidade da educação superior no Brasil. s. I., 2018. 10 p. Disponível em:

<http://download.inep.gov.br/acoes_internacionais/ocde/Consideracoes_OCDE_122 018.pdf>. Acesso em: 27 maio $201 \overline{9}$

BRASIL. INEP. Censo da Educação Básica 2019: notas estatísticas. Brasília, 2020. Disponível em:

<https://download.inep.gov.br/publicacoes/institucionais/estatisticas_e_indicadores/n otas_estatisticas_censo_da_educacao_basica_2019.pdf>. Acesso em: 16 fev. 2021.

BUDD, J. M. The academic library: its context, its purpose and its operation. Englewood: Libraries Unlimited, 1999.

CALVINO, I. As cidades invisíveis. São Paulo: Companhia das Letras, 1997.

CELESTE FILHO, M. Universidade de São Paulo concebida em 1968 por seus professores, alunos e funcionários. Rev. bras. hist. educ., Maringá-PR, v. 17, n. 1 (44), p. 200-233, Janeiro/Março 2017. 
CIDADÃO. In: Dicionário Houaiss. s.l.: Instituto Antonio Houaiss, 2009. Disponível em: <https://houaiss.uol.com.br/corporativo/apps/uol_www/v5-4/html/index.php\#2>. Acesso em: 05/ jan. 2021.

COMPLEMENTAR. In: DICIONÁRIO de Sinônimos. Porto: 7Graus, 2020.

Disponível em: <https://www.sinonimos.com.br/complementar/>. Acesso em: 15 jul. 2020.

CONDORCET, N. Rapport et projet de décret sur l'organisation générale de I'Instruction publique. In: Enfance, tome 42, n4, 1989. pp. 7-32. Disponível em: $<$ https://www.persee.fr/doc/enfan_0013-7545_1989_num_42_4_1898>. Acesso em: 06 mar. 2020.

CUNHA, L. A. A educação brasileira na primeira onda laica: do império à república. Rio de Janeiro: Edição do Autor, 2017.

CUNHA, L. A. (a). A universidade crítica: o ensino superior na república populista. 3. ed. São Paulo: Ed. Unesp, 2007. 216 p.

CUNHA, L. A. (b). A universidade reformada: o golpe de 1964 e a modernização do ensino superior. 2. ed. São Paulo: Ed. Unesp, 2007. 300 p.

CUNHA, L. A. A universidade temporã: o ensino superior da Colônia à Era de Vargas. Rio de Janeiro: Civilização Brasileira: Edições UFC, 1980. 295 p. (Coleção Educação e Transformação; v. 1).

CUNHA, L. A. Autonomia universitária: teoria e prática. In: VESSURI, H. (Org.). Universidad e investigación científica. Buenos Aires: CLACSO, Consejo Latinoamericano de Ciencias Sociales, 2006.

CUNHA, M. B. A biblioteca universitária na encruzilhada. Datagramazero, Rio de Janeiro, v. 11, p. 1-20, 2010.

CUNHA, M. B.; CAVALCANTI, C. R. de O. Dicionário de biblioteconomia e arquivologia. Brasília: Briquet de Lemos, 2008.

CUNHA, M. B.; DIOGENES, F. C. B. A trajetória da biblioteca universitária no Brasil no período de 1901 a 2010. Encontros Bibli, Florianópolis, v. 21, p. 100, 2016.

DIÓGENES, F. C. B.; CUNHA, M. B. Desenvolvimento das universidades e bibliotecas universitárias na Idade Média até à Modernidade. RDBCI: Revista Digital de Biblioteconomia e Ciência Da Informação, v.15, n.1, p.99-129, 2017. Disponível em: <https://periodicos.sbu.unicamp.br/ojs/index.php/rdbci/article/view/8646007>. Acesso em: 28 abr. 2019. 
DIOGENES, F. C. B. Os novos papéis da biblioteca universitária brasileira. 2012. Tese (Doutorado em Ciências da Informação) - Faculdade de Ciência da Informação, Universidade de Brasília, Brasília, 2012.

ÉTICA. In: Dicionário Houaiss. s.I.: Instituto Antonio Houaiss, 2009. Disponível em: <https://houaiss.uol.com.br/corporativo/apps/uol_www/v5-4/html/index.php\#1>. Acesso em: 05 jan. 2021.

FÁVERO, M. L. A. A Universidade no Brasil: das origens à Reforma Universitária de 1968. Educar, Curitiba, n. 28, p. 17-36, 2006. Disponível em: $<$ http://www.scielo.br/scielo.php?script=sci_arttext\&pid=S0104$40602006000200003 \& \operatorname{lng}=$ en\&nrm=iso $>$. Acesso em:13 maio 2019.

FERNANDES, F. Universidade brasileira: reforma ou revolução? São Paulo: Expressão Popular, 2020.

FERRARO, A. R. Liberalismos e educação. Ou por que o Brasil não podia ir além de Mandeville. Revista Brasileira de Educação, v. 14 n. 4, p. 308-325, maio/ago. 2009.

FERREIRA, S. A universidade do século XXI: concepções, finalidades e contradições. 2009. 305 f. Tese (Doutorado) - Faculdade de Educação, Universidade Federal de Goiás, Goiânia, 2009.

FERREIRA JR., A.; BITTAR, M. Artes liberais e ofícios mecânicos nos colégios jesuíticos do Brasil colonial. Rev. Bras. Educ., Rio de Janeiro, v. 17, n. 51, p. 693716, Dez. 2012. Disponível em: $<$ http://www.scielo.br/scielo.php?script=sci_arttext\&pid=S1413$24782012000300012 \& \mathrm{lng}=\mathrm{en} \& \mathrm{nrm}=\mathrm{iso}>$. Acesso em: $18 \mathrm{Fev} .2021$.

FLICKINGER, H. G. Herança e futuro do conceito de formação (Bildung). Educ. Soc., Campinas, v. 32, n. 114, p. 151-167, jan.-mar. 2011.

FRANÇA. Décret portant organisation de I'Université. Tuileries, 1808. Disponível em: <http://rhe.ish-lyon.cnrs.fr/sites/default/files/decret_du_17_mars_1808.pdf>. Acesso em: 05 maio 2019.

HALL, S. A identidade cultural na pós-modernidade. 11. ed. Rio de Janeiro: DP\&A, 2006.

HARVARD UNIVERSITY. Historical Facts. Disponível em: <https://www.harvard.edu/about-harvard/harvard-glance/history/historical-facts>. Acesso em: 02 abr. 2020.

HEY, A. P.; CATANI, A. A USP e a formação de quadros de dirigentes. In: MOROSINI, Marilia Costa (org.). A Universidade no Brasil: concepções e modelos. Brasília: Inep, 2011. p. 231-244. 
HOBSBAWN, E. J. A era das revoluções: 1789-1848. São Paulo: Paz e Terra, 2011.

HUMBOLDT, W. von. On the Internal and External Organization of the Higher Scientific Institutions in Berlin. 1810. Disponível em: <http://ghdi.ghidc.org/sub_document.cfm?document_id=3642>. Acesso em: 05 maio 2019.

IFLA. About the Information Literacy Section. Disponível em: $<$ https://ifla.org/about-information-literacy>. Acesso em: 21 abr. 2020.

LEUPP, H. L. Probable Trends in University Libraries. College and Research Libraries, v. 1, n. 1, dez. 1939. Disponível em:

<https://crl.acrl.org/index.php/crl/article/view/9766/11212>. Acesso em: 21 abr. 2020.

LIMA, L. C.; AZEVEDO, M. L. N. de; CATANI, A. M. O processo de Bolonha, a avaliação a educação superior e algumas considerações sobre a Universidade Nova. Avaliação, Campinas; Sorocaba, SP, v. 13, n. 1, p. 7-36, mar. 2008.

LUZ, V. P. da; SOUZA, S. C. de. Dicionário Enciclopédico de Direito. [s.I.]: Editora Manole, 2015. Disponível em:

<https://integrada.minhabiblioteca.com.br/\#/books/9788520449172/>. Acesso em: 24 fev. 2021.

MELLO, A. F. de; DIAS, M. A. R. Os reflexos de Bolonha e a América Latina: problemas e desafios. Educ. Soc., Campinas, v. 32, n. 115, p. 413-435, abr.-jun. 2011. Disponível em <http://www.cedes.unicamp.br>. Acesso: 21 jul. 2021.

MENDONÇA, A. W. P. C. A universidade no Brasil. Revista Brasileira de Educação, Rio de Janeiro, n. 14, p. 131-150, maio/ago. 2000. Disponível em: $<$ http://www.scielo.br/scielo.php?script=sci_arttext\&pid=S1413$24782000000200008 \&$ Ing=en\&nrm=iso $>$. Acesso em: 02 maio 2019.

MENDES, K. Dal S.; SILVEIRA, R. C. de C. P.; GALVÃO, C. M. Revisão integrativa: método de pesquisa para a incorporação de evidências na saúde e na enfermagem. Texto contexto: Enfermagem, Florianópolis, v. 17, n. 4, p. 758-764, 2008. Disponível em: <http://www.scielo.br/scielo.php?script=sci_arttext\&pid=S010407072008000400018\&lng=en\&nrm=iso>. Acesso em 05 jun. 2019.

MENEGHEL, S. M. A crise da universidade moderna no Brasil. 2001. 330p. Tese (doutorado) - Universidade Estadual de Campinas, Faculdade de Educação, Campinas, SP. Disponível em: <http://www.repositorio.unicamp.br/handle/REPOSIP/252072>. Acesso em: 28 jan. 2020. 
METRICAS.EDU. Times Higher Education Latin America Ranking 2020.

Disponível em: <https://metricas.usp.br/times-higher-education-latin-america-ranking2020/>. Acesso em: 02 dez. 2020.

MÖLLMANN, A. D. S. O legado da bildung. 2011. 89 f. Tese (Doutorado em Educação) - Pontifícia Universidade Católica do Rio Grande do Sul, Porto Alegre, 2011.

MUSCARÁ, F. Sobre la natureza de los estudios universitarios. Revista Histedbr On-line, Campinas, n. 45, p.3-23, mar. 2012. Disponível em:

$<$ https://periodicos.sbu.unicamp.br/ojs/index.php/histedbr/issue/view/1587> Acesso em: 5 jun. 2019

NASCIMENTO, L. dos S. Informação e Educação: as origens da Information Literacy - um estudo do relatório "The Information Service Environment Relationships and Priorities", de Paul Zurkowski. 2018. Dissertação (Mestrado em Cultura e Informação) - Escola de Comunicações e Artes, Universidade de São Paulo, São Paulo, 2018. Disponível em:

$<$ http://www.teses.usp.br/teses/disponiveis/27/27151/tde-03122018-153225/>. Acesso em: 06 mar.2019

NEMI, A. L. L. A Escola Paulista de Medicina: a escola paulista de medicina. In: RODRIGUES, J.; NEMI, A. L. L; LISBOA, K. M.; BIONDI, L. (org.). A Universidade Federal de São Paulo aos 75 Anos: ensaios sobre história e memória. São Paulo: Unifesp, 2008. p. 93-140.

NEMI, A.. A Escola Paulista de Medicina e o Hospital São Paulo entre os anos de 1960 e 1980: o tempo vivido, o tempo rememorado e o tempo narrado. In: MOTA, A.; MARINHO, M. G. S. M. C.; NEMI, A. (org.). Medicina e contextos de exceção: histórias, tensões e continuidades. Santo André: Ufabc, 2017. p. 63-86. (Coleção Medicina, Saúde \& História).

NEWMAN, J. H. The Idea of a University Defined and Illustrated: in nine discourses delivered to the catholics of dublin. S.L: The Project Gutenberg, 2008. Disponível em: <https://www.gutenberg.org/files/24526/24526-pdf.pdf>. Acesso em: 07 dez. 2020.

NICOLAU, M. F. A. O conceito de Formação Cultural (Bildung) em Hegel. 2013. 203 f. Tese (Doutorado) - Faculdade de Educação, Universidade Federal do Ceará, Fortaleza, 2013. Disponível em:

<http://www.repositorio.ufc.br/bitstream/riufc/6047/1/2013-TESE-MFANICOLAU.pdf>. Acesso em: 05 jun. 2019

OECD. Repensando a garantia de qualidade para o ensino superior no Brasil. 2018. Disponível em:

<http://download.inep.gov.br/acoes_internacionais/ocde/Repensando_a_Garantia_de 
_Qualidade_para_o_Ensino_Superior_no_Brasil_PT.pdf $>$. Acesso em: 27 de maio 2019

OLIVEIRA, T. A universidade medieval: uma memória. Mirabilia: Revista Eletrônica de História Antiga e Medieval, n.6, 2006. Disponível em:

$<$ https://ddd.uab.cat/record/112049>. Acesso em: 05 de maio 2019

ORLANDI, E. P. Análise de discurso: princípios e procedimentos. 6ª edição.

Campinas: Pontes, 2005.

PEREIRA, E. M. de A. Educação Geral: com qual propósito? In: PEREIRA, E. M. de A. (org.). Universidade e educação geral: para além da especialização. Campinas: Editora Alínea, s.d.

PERROTTI, E. Infoeducação: um passo além científico-profissional. Inf. Prof., Londrina, v. 5, n. 2, p. 04 - 31, jul./dez. 2016. Disponível em:

$<$ https://www.researchgate.net/publication/315940355_Infoeducacao_um_passo_ale m_cientifico-profissional>. Acesso em: 05 de dez. 2020.

PIERUCCINI, I. A ordem informacional dialógica: estudo sobre a busca de informação em Educação. 2004. 194 f. Tese (Doutorado) - Escola de Comunicações e Artes, Universidade de São Paulo, São Paulo, 2004.

REITZ, J. M. ODLIS: Online Dictionary for Library and Information Science. Danbury: Abc-clio, 2013. Disponível em: <https://www.abc-clio.com/ODLIS/odlis_a.aspx>. Acesso em: 05 jun. 2019

SANTOS, B. de S. Da ideia de Universidade a Universidade de ideias. Revista Crítica de Ciências Sociais, n. 27/28, p. 11-62, junho. 1989.

SÃO PAULO. Decreto no 6283, de 25 de janeiro de 1934. Cria a Universidade de São Paulo e dá outras providências. São Paulo, SP, Disponível em: <https://www.al.sp.gov.br/norma/130436>. Acesso em: 12 ago. 2020.

SENATE AND HOUSE OF REPRESENTATIVES OF THE UNITED STATES OF AMERICA. Morrill Act. 1862. Disponível em:

$<$ https://www.ourdocuments.gov/doc.php?flash=false\&doc=33\&page=transcript>. Acesso em: 05 maio 2019

SERVIÇO DE ARQUIVO PERMANENTE DO ARQUIVO CENTRAL DA UNICAMP. História. Disponível em: <https://www.unicamp.br/unicamp/index.php/historia\#1960>. Acesso em: 04 dez. 2020.

SEVERINO, A. J. A busca do sentido da formação humana: tarefa da Filosofia da Educação. Educação e Pesquisa, São Paulo, v.32, n.3, p. 619-634, set./dez. 2006. 
SEVERINO, A. J. Desafios da formação humana no mundo contemporâneo. Revista de Educação: PUC, Campinas, v. 29, p. 153-164, 2010. Disponível em:

<http://periodicos.puc-campinas.edu.br/seer/index.php/reveducacao/article/view/50>. Acesso em: 26 maio 2019.

SEVERINO, A. J. Educação e universidade: conhecimento e construção da cidadania. Interface: Comunicação, Saúde e Educação, Botucatu, v. 6, n.10, p. 117 124, 2002. Disponível em: <http://www.scielo.br/pdf/icse/v6n10/15.pdf>. Acesso em: 26 maio 2019.

SEVERINO, A. J. Expansão do ensino superior: contextos, desafios, possibilidades. Avaliação: UNICAMP, Campinas, v. 14, p. 253-266, 2009. Disponível em: $<\mathrm{http}: / /$ www.scielo.br/scielo.php?script=sci_arttext\&pid=S1414$40772009000200002 \&$ Ing=en\&nrm=iso>. Acesso em: 26 maio 2019.

SEVERINO, A. J. Integrar cultura e humanismo: desafio pedagógico da Filosofia no Ensino Superior. Educar em Revista, Curitiba, n. 46, p. 21-35, 2012. Disponível em: <http://www.scielo.br/scielo.php?script=sci_arttext\&pid=S0104$40602012000400003 \&$ Ing=en\&nrm=iso > . Acesso em: 06 maio 2019.

SIDOU, J. M. Othon (org.). Dicionário Jurídico. [s.I.]: Grupo GEN, 11aㅡ edição, 2016. Disponível em: <https://integrada.minhabiblioteca.com.br/\#/books/9788530973056/>. Acesso em: 24 fev. 2021.

SIEBIGER, R. H. O processo de Bolonha e os novos espaços transnacionais de educação superior latino-americanos: a universidade brasileira em movimento. Cadernos PROLAM/USP, Ano 9, Vol. 2, p. 119-135, 2010.

SILVA, N. da. Da "Revolução Francesa" ao "século XXI": Algumas notas acerca do sistema educacional francês. História da Educação, n. 23, p. 97-123, Set/Dez 2007. Disponível em: <http//fae.ufpel.edu.br/asphe>. Acesso em: 04 mar. 2020.

SILVEIRA, Z. S. da; BIANCHETTI, L. Universidade moderna: dos interesses do Estado-nação às conveniências do mercado. Revista Brasileira de Educação, v. 21, n. 64, p. 79-99, jan.-mar. 2016. Disponível em: <http://dx.doi.org/10.1590/S141324782016216405>. Acesso em: 09 mar. 2020.

SGUISSARDI, V. A universidade no Brasil: dos modelos clássicos aos modelos de ocasião? In: MOROSINI, M. (org). A universidade no Brasil: concepções e modelos. 2. ed. Brasília: Instituto Nacional de Estudos e Pesquisas Educacionais Anísio Teixeira, 2011.

SOUZA, J. G. Evolução histórica da universidade brasileira: abordagens preliminares. Revista da Faculdade de Educação: PUCCAMP, Campinas, v. 1, n. 1, p. 42-58, agosto. 1996. Disponível em: <http://periodicos.puccampinas.edu.br/seer/index.php/reveducacao/article/view/461 >. Acesso em: 02 maio 2019. 
TRINDADE, H. Brasil. In: GUADILLA, C. G. (Ed.). Pensamiento universitario latinoamericano: pensadores y forjadores de la universidad latinoamericana. Caracas: Cendes: lesalc-Unesco: Bid \& Co. Editor, 2008.

UNIVERSIDADE DE SÃO PAULO. Resolução n² 2226, de 08 de julho de 1981. Dispõe sobre a criação do Sistema de Bibliotecas da Universidade de São Paulo e dá outras providências. Criação do Sistema de Bibliotecas da Universidade. São Paulo, SP, 09 jul. 1981. Disponível em: <https://www.aguia.usp.br/noticias/resolucao2226-08-julho-1981/>. Acesso em: 02 dez. 2020.

UNIVERSIDADE DE SÃO PAULO. Resolução nํ 3461, de 7 de outubro de 1988. Baixa o Estatuto da Universidade de São Paulo. Estatuto da Universidade de São Paulo. São Paulo, SP: Doe, 8 out. 1988. Disponível em:

<http://www.leginf.usp.br/?post_type=resolucao\&p=6314>. Acesso em: 02 dez. 2020.

UNIVERSIDADE DE SÃO PAULO. Resolução nํ3571, de 29 de agosto de 1989. Altera e consolida o Regimento Interno do Sistema Integrado de Bibliotecas da Universidade de São Paulo e revoga as Resoluções 3.008, de 19.11.1985 e 3.009, de 2.12.1985. Resolução № 3571, de 29 de Agosto de 1989. São Paulo, SP: DOE, 30 ago. 1989. Disponível em: <http://www.leginf.usp.br/?resolucao=resolucao-no3571-de-29-de-agosto-de-1989>. Acesso em: 02 dez. 2020.

UNIVERSIDADE DE SÃO PAULO. Resolução no 3745, de 19 de outubro de 1990. Baixa o Regimento Geral da Universidade de São Paulo. Regimento Geral da Universidade de São Paulo. São Paulo, SP: Doe, 23 out. 1990. Disponível em: <www.leginf.usp.br/?resolucao=resolucao-no-3745-de-19-deoutubro-de-1990>. Acesso em: 01 out. 2019.

UNIVERSIDADE DE SÃO PAULO. Resolução nํ5776, de 17 de agosto de 2009. Baixa o Regimento do Sistema Integrado de Bibliotecas da Universidade de São Paulo. Regimento do Sistema de Bibliotecas da Usp. São Paulo, SP: Doe, 19 ago. 2009. Disponível em: <www.leginf.usp.br/?resolucao=consolidada-resolucaono-5776-de-17-de-agosto-de-2009-2>. Acesso em: 01 out. 2019.

UNIVERSIDADE ESTADUAL DE CAMPINAS. Deliberação CONSU-A-015/2013, de 06 de agosto de 2013. Dispõe sobre o Regimento Interno do Sistema de Bibliotecas da UNICAMP. Campinas, SP: Doe, 14 ago. 2013. Disponível em:

<https://www.pg.unicamp.br/mostra_norma.php?id_norma=3425>. Acesso em: 03 maio 2020.

UNIVERSIDADE ESTADUAL DE CAMPINAS. Estatutos da Universidade Estadual de Campinas. Campinas, SP, mar. 2019.

UNIVERSIDADE FEDERAL DE SÃO PAULO. Apresentação. 2014. Disponível em: $<$ https://unifesp.br/institucional/institucionalsub/apresentacao >. Acesso em: 05 out. 2020. 
UNIVERSIDADE FEDERAL DE SÃO PAULO (a). Equipe. Disponível em: <https://unifesp.br/reitoria/bibliotecas/equipe>. Acesso em: 05 dez. 2020.

UNIVERSIDADE FEDERAL DE SÃO PAULO. Estatuto e Regimento Geral. São Paulo, 2011.

UNIVERSIDADE FEDERAL DE SÃO PAULO (b). Organograma. Disponível em: $<$ https://unifesp.br/reitoria/bibliotecas/institucional/organograma> Acesso em: $07 \mathrm{dez}$. 2020.

UNIVERSIDADE FEDERAL DE SÃO PAULO (c). Plano de desenvolvimento institucional Unifesp: PDI 2016-2020. São Paulo, 2017. 211 p. Disponível em: $<$ https://www.unifesp.br/images/docs/PDI/PDI_Unifesp_20162020_vs_09112017.pdf>. Acesso em: 21 set. 2020.

UNIVERSIDADE FEDERAL DE SÃO PAULO. Regimento interno da Coordenadoria da Rede de Bibliotecas da Unifesp. São Paulo, 2016. Disponível em: <https://bibliotecas.unifesp.br/images/documentos/REGIMENTO.pdf>. Acesso em: 05 jan. 2021.

UNIVERSITY COLLEGE DUBLIN. UCD President's Office. Disponível em: <http://www.ucd.ie/president/universityhistory/> Acesso em: 05 maio 2019.

VERGER, J. Homens e saber na Idade Média. São Paulo: EDUSC, 1999. 